\begin{abstract}
UNIVERSIDADE DE SÃO PAULO
FACULDADE DE FILOSOFIA, LETRAS E CIÊNCIAS HUMANAS

DEPARTAMENTO DE ANTROPOLOGIA PROGRAMA DE PÓS-GRADUAÇÃO

EM ANTROPOLOGIA SOCIAL
\end{abstract}

SOBRE ABOLICIONISMOS PENAIS: A Prática de Especular Histórias para Abolir Grades

VERSÃO CORRIGIDA

SÃO PAULO

2019 



\title{
SOBRE ABOLICIONISMOS PENAIS: A Prática de Especular Histórias para Abolir Grades
}

\author{
Dissertação apresentada ao Programa de Pós- \\ Graduação em Antropologia Social do \\ Departamento de Antropologia da Faculdade de \\ Filosofia, Letras e Ciências Humanas da \\ Universidade de São Paulo para a obtenção do \\ título de Mestre em Antropologia.
}

Orientadora: $\operatorname{Prof}^{\mathrm{a}}$. Dr ${ }^{\mathrm{a}}$. Laura Moutinho

VERSÃO CORRIGIDA

SÃO PAULO

2019 

MADER, Caio do Amaral. Sobre Abolicionismos Penais: A Prática de Especular Histórias para Abolir Grades. 2019. 170f. Dissertação (Mestrado) apresentada à Faculdade de Filosofia, Letras e Ciências Humanas da Universidade de São Paulo para obtenção do título de Mestre em Antropologia.

MADER, Caio do Amaral. About Penal Abolitionisms: The Practice of Speculating Stories to Abolish Bars. 2019. 170f. Dissertação (Mestrado) - Faculdade de Filosofia, Letras e Ciências Humanas, Universidade de São Paulo, São Paulo, 2019.

Aprovado em:

Banca Examinadora

Prof. Dr. Instituição

Julgamento Assinatura

Prof. Dr. Instituição

Julgamento Assinatura

Prof. Dr. Instituição

Julgamento Assinatura

Prof. Dr. Instituição

Julgamento Assinatura 

Autorizo a reprodução e divulgação total ou parcial deste trabalho, por qualquer meio convencional ou eletrônico, para fins de estudo e pesquisa, desde que citada a fonte.

Catalogação na Publicação

Serviço de Biblioteca e Documentação

Faculdade de Filosofia, Letras e Ciências Humanas da Universidade de São Paulo

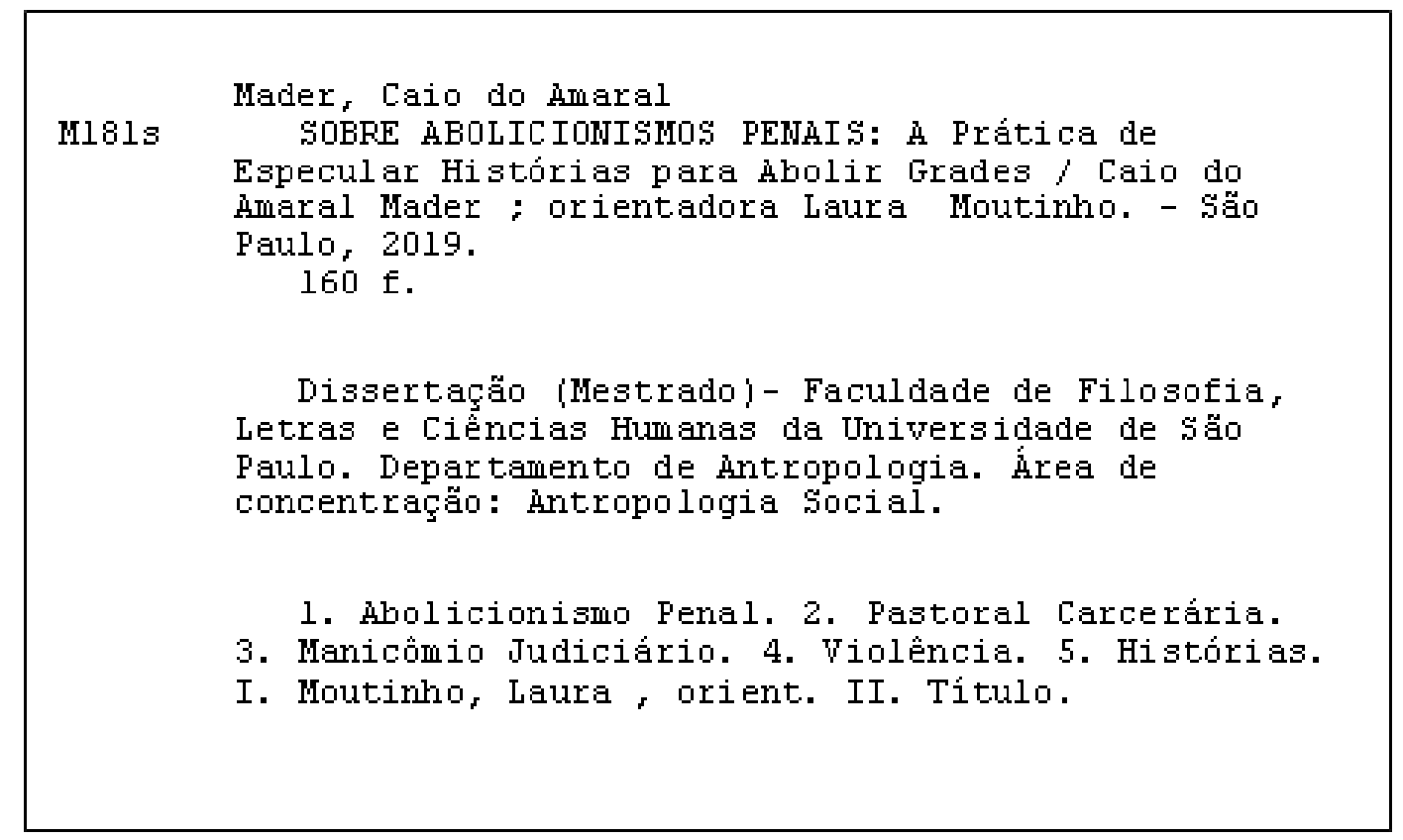





\section{ENTREGA DO EXEMPLAR CORRIGIDO DA DISSERTACÃO/TESE}

\section{Termo de Ciência e Concordância do (a) orientador (a)}

Nome do (a) aluno (a): Caio do Amaral Mader

Data da defesa: 29/11/2019

Nome do Prof. (a) orientador (a): Profa. Dra. Laura Moutinho

Nos termos da legislação vigente, declaro ESTAR CIENTE do conteúdo deste EXEMPLAR CORRIGIDO elaborado em atenção às sugestões dos membros da comissão Julgadora na sessão de defesa do trabalho, manifestando-me plenamente favorável ao seu encaminhamento e publicação no_Portal Digital de Teses da USP.

São Paulo, 19/02/2020

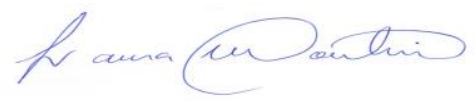

(Assinatura do (a) orientador (a) 

Para minha avó Anna Maria Thereza 



\section{Agradecimentos}

Em tempos não muito animadores para a Educação pública, acredito ser importante demarcar, primeiramente, que a presente pesquisa não teria sido possível sem o apoio financeiro do $\mathrm{CNPq}$, cuja verba pública é um dos principais meios de financiamento da produção de conhecimento científico, distribuído em um amplo leque de áreas do saber, no Brasil. É também uma pesquisa realizada em uma universidade pública, à qual me sinto honrado por ter feito parte tanto como aluno de bacharelado quanto de pós-graduação, compreendendo um período total de oito anos em minha formação profissional.

Nessa longa trajetória de aprendizado afetivo e intelectual, não poderia deixar de agradecer, em primeiro lugar, à Heloísa Buarque de Almeida, que foi professora de minha primeira disciplina de Antropologia, quando ainda cursava a graduação em Relações Internacionais, no ano de 2014. Ali, fui fisgado para uma área do saber que não pretendo mais sair. Assim como alguns outros, vim a me somar no grupo de internacionalistas que se encantaram pela Antropologia e hoje nela se definem profissionalmente. Foi nesse mesmo ano que cursei a disciplina optativa Antropologia das Emoções, ministrada pela professora Laura Moutinho, e que me deu a certeza tanto da área que seria meu mestrado quanto de quem seria minha orientadora. Por isso, agradeço imensamente à Laura cujo carinho e dedicação profissional me formaram nesse primeiro degrau do mundo acadêmico, o qual pode ser, muitas vezes, solitário e opressor. Descobrir que um momento de orientação pode ser tão leve quanto um happy hour numa quinta-feira foi um alento entre tantos de uma relação tão produtiva quanto respeitosa. Contudo, ascender ao primeiro degrau teria sido impossível sem o compartilhamento intelectual e afetivo que tive com a professora Ana Lúcia Pastore Schritzmeyer, quem foi minha orientadora na iniciação científica. Sua competência e ternura dedicados nessa parceria, ainda que por um período breve quando comparado ao fôlego de um mestrado, foram essenciais na minha formação e se refletem no resultado deste trabalho. Fico feliz que nossos caminhos tenham se cruzado novamente para mais uma parceria de pesquisa na reta final do mestrado e espero que venham a se cruzar muitas vezes ainda! Obrigado por acompanharme ao cruzar a porta para esse vasto mundo e por continuar subindo a escada ao meu lado. Reservo um agradecimento especial também a Sérgio Carrara e à Larissa Nadai, os quais tive a honra de ter em minha banca de qualificação.

$\mathrm{O}$ aconchego não seria completo sem o agradecimento ao grupo de orientandos 
do qual fui parte. Meu muito obrigado a Phillip Willians (um dos internacionalistas fisgados!), Pedro Lopes, Milena Mateuzi, Léa Tosold, Valéria Alves, Denise Pimenta, Mariana Boujikian, Bruna Galicho, Thais Tiriba, Alessandra Tavares, Laís Miwa, Márcio Zamboni e Maria Isabel Zanzotti. O compartilhamento que construímos por meio da escrita e leitura durante reuniões de orientação e conversas informais foi fundamental para que este trabalho tomasse corpo. Meu muito obrigado! Agradeço também aos meus colegas e amigos de turma com quem, apesar do breve período, teci valorosas trocas e contribuições que fizeram da experiência do mestrado um momento ímpar que rendeu e continua rendendo muitos frutos, não somente com a finalização de nossas dissertações, mas com os laços afetivo-intelectuais que perduram para além de nossas escritas.

Minha gratidão aos(às) funcionários(as) do Departamento de Antropologia não só pelo apoio institucional mas pelo companheirismo que tive a oportunidade de construir na condição de bolsista da Revista de Antropologia (RA), sobretudo, Juciele Borges, Celso Gonçalves e Edinaldo Lima. Foi também esse período de estágio que me trouxe para perto de competentes professores, por quem tenho admiração; são eles a Profa. Sylvia Caiuby e o Prof. Pedro Cesarino. Aprendi muito participando da Comissão Editorial da RA, oportunidade essa que também não teria sido possível sem o apoio de Laura Moutinho.

No âmbito da Pastoral Carcerária (PCr), agradeço aos membros do Grupo de Trabalho de Saúde Mental e Liberdade, cuja dedicação e empenho ao trabalho nos manicômios judiciários foram, tanto quanto inspiradores, combustível de uma relação de afeto que consolidou a amizade e confiança para a consecução desta dissertação. São eles(as): Sara Antunes, Fábio Mallart, Monike Rocha, Maria Cembranelli, Cristina Senlle, Luísa Cytrynowicz, Andrea Barros, Camila Ribeiro, Francisco Crozera, Ana Faria e Catarina Pedroso. Para além do GT, não menos importante foram os acolhimentos que me embalaram desde os primeiros passos enquanto agente pastoral e pelos quais sou extremamente grato: Nice Rocha, Érica e Anderson Silva, Marcelo Naves, Gabrielle Nascimento, Anna Carolina Silva, José Coutinho Júnior, Paulo César Malvezzi e Édina Maciel.

Agradeço também a Pe. Valdir João Silveira, por quem nutro um imenso carinho e profunda admiração. Se não fosse por seu trabalho há tantos anos dedicado à Pastoral Carcerária, o GT jamais teria ganhado existência. Foi também graças à sua resiliência e confiança que nosso trabalho sobreviveu aos muitos e densos obstáculos que enfrentamos juntos na busca de "um mundo sem cárceres". Digo com muito orgulho que, além de uma 
referência, Valdir é um grande amigo, cuja amizade espero continuar cultivando a despeito dos rumos sempre mutáveis das histórias que promoveram o cruzamento de nossos caminhos. Agradeço muito sua confiança no trabalho do GT e na construção desta dissertação. Certamente nada teria sido possível sem sua abertura e a ternura com que ouviu as muitas angústias de um aprendiz de pastoral e de antropólogo.

Por fim, agradeço à minha família, para a qual hoje em dia não faço distinção entre aqueles que são parte desde meu nascimento e os que chegaram depois. São muitos os(as) amigos(as) que aguentaram tanto minha ausência e reclusão quanto minhas infindáveis reclamações do processo de escrita. Não poderia enumerá-los(as) aqui, mas sei que saberão quando lerem essa parte. Sei que sabem o quanto a paciência de vocês foi fundamental para que eu chegasse até aqui. Entretanto, não posso deixar de destacar aqueles(as) que mais me apoiaram (e suportaram) nessa jornada. Foram eles(as) que partilharam comigo o lar onde este trabalho foi paulatinamente escrito. Dito isso, agradeço muitíssimo aos meus, ao mesmo tempo, abridores de mundos e acompanhantes de mundos abertos Joaquim, Jesser, Juliana e Dulce. Joaquim, principalmente, por ter sido o primeiro a acreditar, antes de qualquer pessoa e quando tudo indicava a vitória do fechamento, que meus olhos podiam ser abertos à toda beleza e meus ouvidos a todo o som. Obrigado por estar sempre ao meu lado ainda que minha teimosia me faça, até hoje, queimar alguns de seus panos de prato. A esse processo difícil de abertura sinestésica, porém não desprovido de muito amor, veio se somar Jesser, que, embora igualmente confiante na abertura, trouxe seu carinho magmático para que o percurso continuasse. Derretendo trancas, foi possível que aprendêssemos, juntos, a ver e ouvir melhor para assim fazermos e compartilharmos uma casa. Com Juliana, tive a honra de aprender através de sua leitura e escrita, dotadas de um grau de sensibilidade e excelência intelectual únicos. Sua escrita admirável, aprendi com o tempo, vem de sua habilidade para enxergar belezas microscópicas, ainda que sejam tão pequenas quanto um bacilo, ou tão fugazes quanto dois sorrisos que se encontram. Dulce, por fim, chegou com uma energia tão inesgotável quanto seu amor, capaz não só de abrir, mas de unir mundos completamente distintos. Afinal, de que adiantaria a abertura sem que outros tantos mundos para além do conforto do lar pudessem se unir a ele? Obrigado, Dulce, por confeccionar, tão afetuosamente, essas pontes.

À família que conheço desde que abri os olhos para este mundo, meus protetores Cláudio e Marisa, e, principalmente, minha avó Anna Maria Thereza. Todos(as) que realmente me conhecem sabem de minha vó, que me criou e amparou de formas que 
talvez jamais seja capaz de entender a dimensão do que essa relação significa e de como ela me constitui. Ainda que seja apenas a tentativa de uma singela retribuição, é para ela, e seu amor que me permitiu ser quem sou, que dedico esta dissertação. 



\title{
RESUMO
}

Este trabalho procura entender os múltiplos sentidos englobados no lema "Por um mundo sem cárceres" da Pastoral Carcerária (PCr), organização civil ligada à Igreja Católica e dedicada à defesa dos direitos humanos de encarcerados(as) no Brasil e no mundo em linha abolicionista penal. Participei, durante dois anos (2016-2018), do Grupo de Trabalho Saúde Mental e Liberdade vinculado à PCr da Arquidiocese de São Paulo (GT). Como grupo dedicado exclusivamente à questão dos Hospitais de Custódia e Tratamento Psiquiátrico (HCTP), conhecidos também como manicômios judiciários, do Estado de São Paulo, a presente dissertação tem como principal intuito discutir como o abolicionismo penal, longe de ser a estrita extinção do sistema carcerário, do qual os HCTPs são também parte, constrói-se no plano cotidiano de visitas de assistência religiosa a essa unidades, política basilar do trabalho da PCr. Argumenta-se que construir "um mundo sem cárceres", enquanto diretriz política, reivindica uma temporalidade ancorada no presente, em que escutar e veicular as histórias registradas por agentes pastorais a partir de idas periódicas a unidades prisionais é estratégia seminal dessa construção, e na qual a produção de documentos, notadamente relatórios de denúncia, desempenha também um papel fundamental.

\section{PALAVRAS-CHAVE}

Abolicionismo Penal; Manicômios Judiciários; Pastoral Carcerária; Violência; Histórias.

\begin{abstract}
This thesis aims to understand the multiple meanings embodied in the motto "For a world without jails" of Pastoral Carcerária (PCr), a civil organization linked to the Catholic Church and dedicated to defending the human rights of prisoners both in Brazil and internationally abiding by penal abolitionism. I have participated, during two years (20162018), of the Mental Health and Freedom Working Group linked to the PCr of the Archdiocese of São Paulo (WG). As a group dedicated exclusively to the issue of the Forensic Hospitals in the State of São Paulo, this dissertation has as its main purpose to discuss how penal abolitionism, far from being the strict extinction of the criminal system, of which the Forensic Hospitals are also part, is built on the daily plan of religious assistance visits to these units, a fundamental policy of the work of the PCr. It is argued that building "a world without jails" stands for a political guideline that claims a temporality anchored in the present, in which listening and conveying stories registered by pastoral agents from periodic visits to prison units is a seminal strategy of this construction. The production of documents, notably complaint reports, also plays a key role at the consecution of " $a$ world without jails".
\end{abstract}

\section{KEYWORDS}

Penal abolitionism; Forensic Hospitals; Pastoral Carcerária; Violence; Histories. 



\section{Sumário}

Introdução...................................................................................................................................................... 1

A Pastoral Carcerária e o GT de Saúde Mental e Liberdade..................................................... 5

Os manicômios judiciários e a Reforma Psiquiátrica Brasileira ................................................ 10

Caderninhos e canetas: algumas considerações metodológicas ............................................ 12

Abolicionismo penal: uma prática de contar e rememorar histórias ....................................... 14

Capítulo 1: A tentativa de "escutar" histórias................................................................................ 18

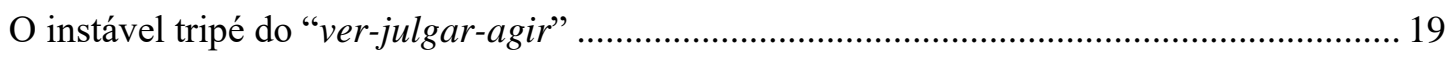

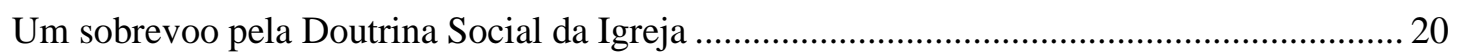

Quando documentos brigam: a "parte social" vs "parte religiosa" .......................................... 24

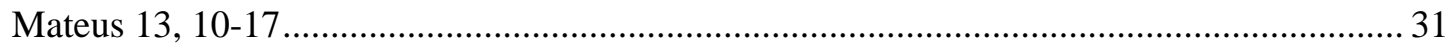

"Caio, vem cá que quero conversar com você. Anota tudo no caderninho" ............................ 33

Quando ver é não enxergar e escutar é não ouvir...................................................................... 37

Capítulo 2: A tentativa de escrever histórias .........................................................................53

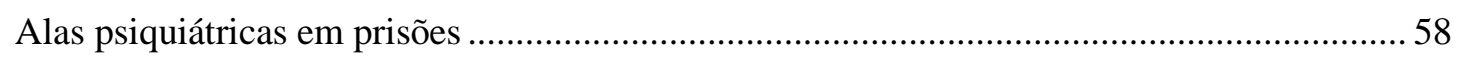

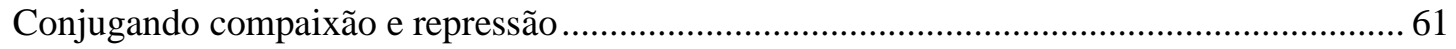

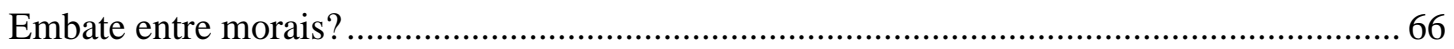

Relatórios e bilhetinhos: o que se transmite através da escrita?........................................... 81

Capítulo 3: Abolicionismo penal como histórias sem inícios e fins........................................... 101

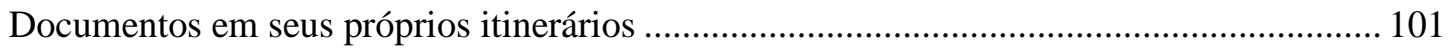

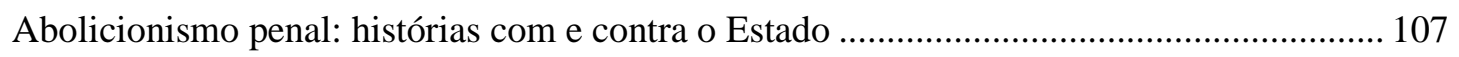

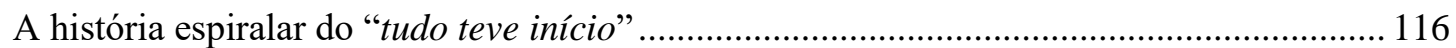

Abolicionismo penal como recusa do "tudo teve início": o que nos dizem os bebês na

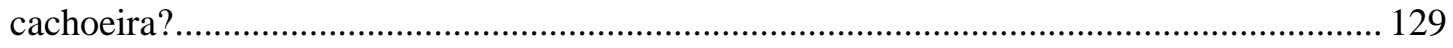

A Antropologia e o Abolicionismo penal como "histórias-até-agora" que contam histórias: para onde nos levam as etnografias? ..................................................................................................... 137

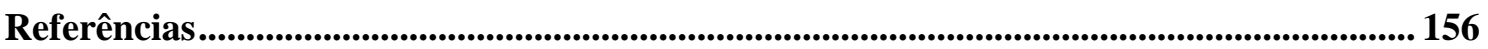


Tel irmã: $X X X X X X X X$ - perguntar para a irmã como está a saúde de seu pai. Quer visita

\title{
Mercedes
}

Tel irmã (Regina): XXXXXXX $\rightarrow$ perguntar como estão seus filhos e sua mãe

\section{Elaine Lima Matr: $X X X X X X$}

\author{
Resultado de exame de cessação de periculosidade \\ atrasado $\rightarrow \underline{\text { VERIFICAR }}$
}

Luis Carlos Borges Matr: XXXXX

Quer ser transferido para Taubaté - ficar perto da família: Ver se é possível

Lilian Mariz $\quad$ Matr: $X X X X X$

Tel(mãe-Regina): XXXXXXX Perguntar se a cirurgia deu certo $\rightarrow \underline{\text { avisar }}$ que está se recuperando bem e que é para Lilian 'tomar juizo'

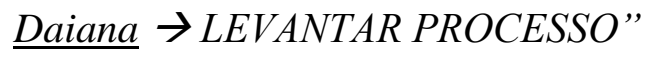

\section{Introdução}

A presente dissertação tem como principal objetivo discutir a diretriz política penal abolicionista da Pastoral Carcerária (PCr), organização católica que se define como uma "pastoral social ligada à Conferência Nacional dos Bispos do Brasil (CNBB)", procurado agir "junto às pessoas presas e suas famílias", como versa em sua homepage ${ }^{1}$. "Por um mundo sem cárcere", sendo um de seus principais lemas norteadores, sintetiza sua postura política de rechaço ao sistema carcerário como política pública de resolução de conflitos da sociedade, reivindicando sua ineficácia não em termos de falta, seja ela de investimento, planejamento ou infraestrutura, mas pela sua própria razão de ser enquanto instituição inexoravelmente violadora à vida humana. Ainda nas palavras de sua homepage, "está claro que encarcerar mais pessoas, em sua maioria pobres e negras, não

\footnotetext{
${ }^{1}$ Fonte: https://carceraria.org.br/a-pastoral-carceraria
} 
diminui a violência; ao contrário, o encarceramento serve para torturar as pessoas mais pobres e gerar ainda mais violência".

O recorte para a discussão do abolicionismo penal, tal como defendido pela $\mathrm{PCr}$, será minha atuação enquanto membro do Grupo de Trabalho Saúde Mental e Liberdade (doravante referido como GT) pertencente à PCr da Arquidiocese de São Paulo, o qual tem como enfoque de atuação a população sob medida de segurança custodiada tanto em Hospitais de Custódia e Tratamento Psiquiátrico (HCTPs), também conhecidos como manicômios judiciários, quanto em alas psiquiátricas de unidades penitenciárias ${ }^{2}$. HCTPs e manicômios judiciários serão, portanto, termos empregados nesta dissertação como nomenclaturas sinônimas. É importante ressaltar que, embora se intitulem "hospitais", essas instituições não estão subordinadas à Secretaria de Saúde, mas à Secretaria de Administração Penitenciária (SAP) do Estado de São Paulo, sendo integrantes do sistema penitenciário.

Desde sua fundação em 2014 e conforme a política de visitas de provisão de assistência religiosa $^{3}$ da PCr às unidades prisionais, o GT realizou, até o início de 2019, visitas quinzenais aos dois HCTPs em Franco da Rocha, cidade localizada na região metropolitana de São Paulo (Hospital de Custódia e Tratamento Psiquiátrico "Professor André Teixeira Lima" I e Hospital de Custódia e Tratamento Psiquiátrico II, doravante referidos, respectivamente, como HCTP I e HCTP II) e semestrais ao que chamarei como HCTP de Taubaté (Hospital de Custódia e Tratamento Psiquiátrico "Dr. Arnaldo Amado Ferreira" de Taubaté), cidade do nordeste paulista. Pretendo, mais adiante, fazer uma contextualização mais detalhada sobre os manicômios judiciários, bem como do regime jurídico-penal da medida de segurança, que se baseia na chamada inimputabilidade ou semi-imputabilidade do indivíduo considerado infrator criminal e justifica seu encaminhamento judicial aos HCTPs. Por ora, destaco que, além de realizar visitas de assistência religiosa, o GT lançou, em agosto de 2018, o relatório Hospitais-Prisão: notas

${ }^{2}$ A nível arquidiocesano, além do GT de Saúde Mental e Liberdade, há o Grupo de Trabalho Mulher e Diversidade, que, em seu boletim informativo, assim define sua atuação: "O Grupo de Trabalho reúne agentes da Pastoral Carcerária para a construção de repertório sobre as questões de gênero e diversidade no ambiente prisional e assim, é um espaço de formação e encontro para quem o compõe e demais envolvidas/os com a temática, também objetivando colaborar na construção e manutenção das políticas públicas relacionadas". Fonte: https://carceraria.org.br/wp-content/uploads/2019/01/Boletiminformativo-1.pdf

${ }^{3}$ As visitas de assistência religiosa têm respaldo jurídico através de normativas nacionais e internacionais, com destaque para a Constituição Federal, a Lei de Execução Penal (LEP) e a Declaração Universal dos Direitos Humanos (Relatório Hospitais-Prisão, 2018:17). 
sobre os manicômios judiciários de São Paulo ${ }^{4}$ (doravante designado como Relatório Hospitais-Prisão), cujo principal objetivo foi divulgar, a partir do registro de relatos de pacientes-detentos $(a s)^{5}$, do corpo funcional, bem como do que vimos e ouvimos nesses espaços, como operam essas instituições de modo a defender sua extinção.

Redigido coletivamente pelo GT e tendo como principal fonte de informação a experiência de visitas aos HCTPs, o documento visa construir uma visão crítica da suposta função terapêutica dessas instituições, bem como das patologias psiquiátricas de que, supostamente, padece a população em medida de segurança. Dessa forma, busca advogar pelo fechamento dessas instituições em conformidade com a luta antimanicomial brasileira, cuja lei 10.216/2001 foi um marco nas políticas de saúde mental do Brasil, mas que, não obstante sua importância, não só teve avanços tímidos no rompimento com alguns paradigmas manicomiais como também passou ao largo do debate em relação aos HCTPs.

Diante desse contexto, portanto, procurarei dar inteligibilidade a uma espécie de paradoxo que, a princípio, caracteriza a atuação da PCr e, por consequência, o GT. Diante do fato de que a extinção de todo sistema prisional soa uma utopia futurista, colocam-se as seguintes questões: como e por que a realização de visitas periódicas a unidades prisionais, as quais incluem os HCTPs e têm como principal objetivo a provisão de assistência religiosa, é um objetivo sintonizado com o abolicionismo penal? Como entender a produção de relatórios pela PCr, notadamente o Relatório Hospitais-Prisão, para a construção de "um mundo sem cárceres”?

Tais questões constituem a espinha dorsal desta dissertação e não tenho a pretensão de respondê-las de forma a construir um argumento em prol dessa ou daquela estratégia como melhor caminho penal abolicionista, como se este fosse uma meta prévia e semanticamente delimitada. Antes, longe de categorizações que reduzam essa diretriz política ao mero fechamento de prisões, amplio o foco para como seu significado é

\footnotetext{
Disponível na íntegra em: https://carceraria.org.br/wpcontent/uploads/2018/08/relatrio_hospitais-priso-gt-sade-mental-e-liberdade-pastoral.pdf

${ }_{5}$ Terminologia que tomo emprestada do Relatório Hospitais- Prisão. Nele, acordamos, enquanto GT, adotar essa categoria binomial com o objetivo de questionar o termo "paciente", referido às pessoas custodiadas nessas instituições. Em outras palavras, optou-se por desnaturalizar o HCTP como uma instituição hospitalar, evidenciando seu caráter prisional e interpelando criticamente seu caráter terapêutico. Tal terminologia não vem dissociada de outra, também binomial, que foi cunhada pelo GT com o objetivo de denotar a relação entre a farmacologia e a moralidade operante nos HCTPs: "tratamento-disciplina" (Relatório Hospitais-Prisão, 2018:14). Esse ponto será objeto de análise no capítulo 2 desta dissertação.
} 
construído e elaborado a partir do que se entende por "um mundo sem cárceres" em seus múltiplos sentidos e elaborações no cotidiano institucional da $\mathrm{PCr}$ e, por extensão, no GT.

Não raro, as ideias em torno de abolicionismo penal vieram associadas a noções várias de violência e sofrimento que tornam a extinção de prisões um imperativo humanitário. Com efeito, a categoria "violência" era meu interesse inicial de pesquisa uma vez que buscava compreender como ela era empregada, em termos êmicos, no âmbito dos manicômios judiciários. Intrigou-me tanto o fato de que essas instituições não são tão conhecidas ou tematizadas tal como o são prisões e manicômios, quanto se o grau de investimento semântico a partir da ideia de "violência", de que são alvo instituições psiquiátricas ou carcerárias por parte de certos atores da sociedade civil e acadêmicos, seria aplicável também aos HCTPs. No entanto, ao longo de minha atuação como agente pastoral, fui percebendo que no que se refere à "violência", embora apresentasse múltiplos sentidos conforme o contexto em que era mobilizada, suas significações recorrentemente refletiam o posicionamento político de extinção do sistema carcerário, este também multivocal. Dito de outro modo, "violência" aparecia a reboque de outros conceitos e diretrizes, dificilmente constituindo-se como um campo semântico autônomo. Assim, de acordo com a PCr, porque presídios são espaços de violência, devem ser extintos.

Essa correlação fez com que me atentasse para o abolicionismo penal não só como um importante norteador do que é violência para a $\mathrm{PCr}$, mas para minha própria inserção enquanto agente pastoral visitante de manicômios judiciários e como a relação que estabeleci com essas instituições se relaciona com noções de violência. Em decorrência, ser agente pastoral deslocou-se de um mero meio de acesso aos manicômios judiciários para um ponto importante de reflexão de como violência é também parte dessa posição institucional e não um atributo que lhe é externo. Fez-se premente, então, entender como essa atuação cotidiana é tanto parte da violência que caracteriza o Estado encarcerador, quanto do "mundo sem cárceres" que a PCr procura construir no presente.

A centralidade que a PCr toma neste trabalho, portanto, torna pertinente fazer uma breve contextualização de seu surgimento, bem como de sua estrutura organizacional, seguido de um histórico suscinto do GT. Em sequência, busco situar o(a) leitor(a) em relação aos manicômios judiciários e alguns conceitos jurídico-psiquiátricos cujo 
entendimento é fundamental para a compreensão das razões pelas quais parte das pessoas capturadas pelo sistema de justiça têm como destino os HCTPs.

\section{A Pastoral Carcerária e o GT de Saúde Mental e Liberdade}

Embora as imbricações entre prisões e Igreja Católica venham desde longa data, no website da PCr temos que as primeiras visitas de assistência religiosa no Brasil remontam à década de 1960, realizadas pela congregação religiosa das Irmãs do Bom Pastor. Entretanto, é só em 1986 que a PCr se institucionaliza como "serviço organizado da $C N B B "$ ", na forma de uma pastoral social. Junto ao seu lema "Por um mundo sem cárceres" soma-se outro que também a identifica: trata-se do versículo bíblico "Estive preso e vieste me visitar" (Mt 25, 36).

O imperativo de visitar a pessoa privada de liberdade, tal como postula esse versículo, é um dos eixos centrais da PCr enquanto ação institucional cotidiana e meio pelo qual realiza, através da mobilização de equipes em todos os estados brasileiros, seu trabalho de assistência religiosa. Além da bíblia, as visitações às unidades penitenciárias fincam raízes em amplo espectro religioso-documental, que agrupa, historicamente, um conjunto de ensinamentos e princípios da teologia católica conhecidos como Doutrina Social da Igreja. De acordo com essa fonte doutrinária, ainda segundo as informações da homepage da PCr, menos do que a promoção de uma assistência circunscrita exclusivamente à dimensão espiritual, o princípio "sócio-transformador" que a baliza deve incidir concretamente "na realidade", buscando sua transformação em benefício do ser humano em sua "ecologia integral", isto é, "suas necessidades, suas aspirações e sonhos" (ibid).

O cárcere, portanto, à luz dessa visão integral, seria instituição altamente aviltante à vida humana e, no que diz respeito ao Brasil, com sua política de encarceramento em massa, particularmente violento aos "grupos sociais marginalizados e empobrecidos, destacadamente jovens, negros e moradores/as das periferias e das áreas urbanas socialmente mais precarizadas" (ibid). Denotando a imprescindibilidade de dimensões sociais e econômicas como parte do escopo de um trabalho evangelizador, a PCr assim sintetiza sua atuação:

A PCr, busca ser a presença de Cristo e de sua Igreja no mundo dos cárceres, caracterizado pela superlotação, condições insalubres e tortura sofrida pelas pessoas privadas de liberdade. Portanto, em seu trabalho

\footnotetext{
${ }^{6}$ Fonte: https://carceraria.org.br/a-pastoral-carceraria\#1541815130503-621cac4b-75d4
} 
de atendimento religioso às pessoas presas os/as agentes pastorais promovem um serviço de escuta e acolhimento, anunciam a Boa Nova, contribuem para o processo de iniciação à vida cristã e para a vivência dos sacramentos, e atuam no enfrentamento às violações de direitos humanos e da dignidade humana que ocorrem dentro do cárcere, pois "todo processo evangelizador envolve a promoção humana" (Doc. Aparecida, p.399). Assim, a evangelização concretiza-se de forma integral, seguindo as orientações da Igreja: “As profundas diferenças sociais, a extrema pobreza e a violação dos direitos humanos (...) são desafios lançados à evangelização" (Puebla, 90) (Ibid).

Esse repertório documental de orientação teológico-católica é de grande relevância para o entendimento de seus objetivos e atuação institucional, como procurarei demonstrar, sobretudo, no Capítulo 1. Adianto, no entanto, que dentre a vasta quantidade de documentos enquadrados no que se denomina Doutrina Social da Igreja, a recorrência de referência aos Documentos de Puebla e de Aparecida em minha trajetória enquanto agente pastoral tornou premente que buscasse entender como eles reverberam atualmente de modo a balizar o trabalho da PCr. Suscintamente, sua importância deve-se ao papel que exerceram enquanto conformadores de uma experiência eclesiológica de cristãos e cristãs, na qual as pastorais sociais, em âmbito latino-americano, desempenharam um papel de extrema relevância. Mais tarde, essa experiência viria a ser interpretada como Teologia da Libertação ${ }^{7}$.

Trata-se dos documentos resultantes, respectivamente, da III Assembleia do Episcopado Latino-americano (1979), realizado no México, na cidade de Puebla, e da V Assembleia do Episcopado Latino-americano (2007), ocorrida na cidade de Aparecida do Norte, no Estado de São Paulo, Brasil. Embora não esteja referenciada nessa citação, o documento de Medellín resultante da II Assembleia do Episcopado Latino-americano (1968), esta realizada na Colômbia, é de igual importância em termos de fonte documental de diretrizes políticas mobilizadas na atualidade pela PCr, assim como por outras pastorais sociais ${ }^{8}$.

Além dos documentos aos quais a PCr faz recorrente referência, existem também aqueles que por ela são produzidos. Vale ressaltar a produção de relatórios de denúncia e informação, e aqui destaco, a título de exemplo, alguns deles: Tortura em Tempos de Encarceramento em Massa, em suas duas edições (a primeira edição de 2016 e sua

\footnotetext{
${ }^{7}$ Para maior aprofundamento a respeito da Teologia da Libertação, ver BOFF, Leonardo. Igreja: carisma e poder. Petrópolis: Vozes, 1982.

${ }^{8}$ Além da PCr, há outras pastorais que se definem como sociais, a saber, a Pastoral Indígena, Pastoral Operária, Pastoral do Povo de Rua, Pastoral Afro, entre outras, cada qual com sua frente de atuação.
} 
atualização em 2018); Luta antiprisional no mundo contemporâneo: um estudo sobre experiências em outras nações de redução da população carcerária (2018); Em defesa do desencarceramento de mulheres: pesquisa sobre o impacto concreto do indulto do dia das mães de 2017 (2018). Todos esses relatórios são de autoria do Escritório Nacional da $\mathrm{PCr}$

Outros documentos, ainda, são produzidos coletivamente com outras organizações, sejam estatais ou da sociedade civil e, nesse quesito, é notório o lançamento, em 2013, da Agenda Nacional pelo Desencarceramento. Trata-se de um documento fruto da parceria da $\mathrm{PCr}$ com mais de quarenta outros entes a fim de propor medidas concretas pautadas pelo desencarceramento, e não reforma ou aprimoramento dos estabelecimentos prisionais, seja pela implementação de políticas públicas ou pelo fortalecimento de práticas comunitárias de resolução de conflitos. $\mathrm{O}$ documento é um agregado de dez propostas que giram em torno de tópicos como: "Suspensão de qualquer investimento em construção de novas unidades prisionais; Limitação máxima das prisões cautelares, redução de penas e descriminalização de condutas, em especial aquelas relacionadas à política de drogas; Ampliação das garantias da execução penal $e$ abertura do cárcere para a sociedade; Proibição absoluta da privatização do sistema prisional; Combate à tortura e desmilitarização das polícias, da política e da vida"9.

Tal panorama institucional é essencial de ser delineado porque coloca em relevo o fato de que a capilaridade é uma característica tão complexa quanto constitutiva da PCr. As parcerias e produção de documentos estão mutuamente implicadas, vide o fato, por exemplo, de que o referido documento serviu de estopim para a criação de frentes estaduais pelo desencarceramento em vários estados da federação, estas igualmente sendo produto de uma articulação de organizações e movimentos sociais aglutinados em torno da promoção e divulgação das propostas da agenda. Desse modo, ser agente pastoral não raro implica ser outra coisa ao mesmo tempo, ou seja, ser agente pastoral não é excludente de ser membro de alguma das frentes estaduais mencionadas ou representante de qualquer outra organização seja ela estatal, um movimento social, uma ONG ou uma universidade.

Esses múltiplos pertencimentos também atravessam a PCr em termos de suas instâncias organizacionais e divisões territoriais de competência. Tal assunto é

\footnotetext{
${ }^{9}$ Fonte: https://desencarceramento.org.br/quem-somos
} 
particularmente complexo a ponto de que meus dois anos de atuação enquanto agente pastoral (2016-2018) não me permitiram adquirir pleno conhecimento dessa dinâmica, mas tampouco acredito que seja imprescindível para os fins a que serve esta dissertação. De todo modo, sintetizo simplificadamente os planos institucionais que estruturam a organização. Em âmbito nacional, temos a organização da $\mathrm{PCr}$ por paróquia, diocese, estados, regionais da CNBB e, finalmente, pela CNBB Nacional. A nível internacional, há representações oficiais a nível do Cone Sul, América do Sul, América Latina e Caribe, Continente Americano e Mundial, este último através da Comissão Internacional de Pastoral Penitenciária Católica (International Catholic Commission for Prison Care ICCPPC), vinculada ao Vaticano. Cada uma dessas instâncias, tanto domésticas quanto internacionais, dispõe de uma coordenação.

Por último, cabe destacar, ainda, a existência do Escritório Nacional da PCr, encabeçado pelo coordenador nacional ${ }^{10}$ juntamente com um vice-coordenador, os quais, à época de minha atuação enquanto agente pastoral, eram, respectivamente, um padre diocesano e um religioso - pertencente à congregação Consolata - e os escritórios estaduais, sendo o coordenador estadual de São Paulo um leigo que se declarava católico. Diferentemente da enumeração organizacional anterior, essas instâncias não são regionais ou territoriais, mas administrativas e, por isso, não englobam sub-regiões, apesar de terem sua competência territorialmente delimitada. É válido ressaltar também que o Escritório Nacional está localizado em São Paulo, devido ao entendimento de que a situação carcerária desse estado é particularmente delicada, uma vez que o estado paulista é o que concentra a maior população prisional do país ${ }^{11}$.

Dentro desse organograma, o GT vincula-se à PCr em nível da Arquidiocese de São Paulo, que nada mais é do que um conjunto regiões episcopais ${ }^{12}$. Desde seu surgimento em 2014, o GT foi marcado pela diversidade dos seus componentes. Ele aglutinou agentes religiosos que trabalhavam na PCr desde longa data, bem como membros de organizações laicas como a Ouvidoria da Defensoria Pública do Estado de São Paulo, o Centro de Atendimento Multidisciplinar da Regional Criminal da

10 À época de meu envolvimento, o coordenador nacional da PCr era também o coordenador arquidiocesano, além de ser coordenador a nível latino-americano.

${ }^{11}$ Segundo dados do relatório mais recente lançado pelo INFOPEN, em 2017, são 726.712 pessoas presas no país, sendo 240.061 somente no Estado de São Paulo. Fonte: https://carceraria.org.br/agendanacional-pelo-desencareramento/nota-tecnica-sobre-a-proposta-de-privatizacao-dos-presidios-em-sp Brasilândia.

${ }^{12}$ No caso da Arquidiocese de São Paulo, são elas: Sé, Belém, Ipiranga, Santana, Lapa e 
Defensoria Pública de São Paulo (CAMCrim), o Conselho Regional de Psicologia (CRP) de São Paulo e o Instituto Terra, Trabalho e Cidadania (ITTC). Além desses, ainda, havia a participação de estudantes de psicologia social e ciências sociais (como no meu caso, porém com ingresso em 2016), estagiárias dos Escritórios Nacional e Estadual da PCr e o advogado do Escritório Estadual. Embora tivesse o nome de GT, sua função não era diferente da de outras equipes pastorais, cada qual voltada para uma região específica da circunscrição arquidiocesana onde há unidades prisionais. Em nosso caso, dedicávamonos, exclusivamente, a visitar os HCTPs paulistas, embora a população em medida de segurança, como dito antes, esteja também em alas psiquiátricas de alguns presídios como falarei no capítulo 1. Entretanto, devido à dimensão dos HCTPs frente ao número de componentes do GT, entendeu-se que não haveria como extrapolar as visitas para além dos manicômios judiciários ${ }^{13}$.

Não obstante essa limitação de recursos humanos, o Relatório Hospitais-Prisão não deixou de problematizar a questão das alas psiquiátricas, intensamente conectadas com os HCTPs. Com efeito, como ressalta o relatório, não há como compreender o funcionamento dos HCTPs sem um entendimento das várias instituições que a eles se justapõem, conformando o que o GT nomeou, no documento, de "rede manicomialprisional” (Relatório Hospitais-Prisão, 2018:41). Como decorrência dessa visão, portanto, o relatório tem como base o pressuposto de que resulta ineficaz a estrita defesa de extinção dos HCTPs, porquanto a problemática manicomial-prisional que o caracteriza extrapola suas fronteiras territoriais.

Nesse sentido, a experiência da institucionalização nos HCTPs é apenas uma faceta do problema, uma vez que muitos indivíduos, mesmo desinternados, têm seus fluxos marcados pelo encaminhamento judicial a outras instituições, sejam elas de saúde, de assistência social ou mesmo outros espaços prisionais, os quais não deixam de operar a partir de lógicas contentivas ou igualmente violadoras. Não raro, a circulação das pessoas capturadas pelo sistema de justiça resulta no retorno aos manicômios judiciários, sendo enquadradas como casos de reincidência. É a partir dessa leitura metaforizada pela ideia de "rede" que o texto faz a ressalva de que "Embora esse relatório não tenha como objetivo apresentar propostas de substituição dos manicômios judiciários, sublinha-se

${ }^{13}$ Em 2018, a população custodiada nos três HCTPs do estado compreendia 748 internos(as). Dados obtidos no site da Secretaria de Administração Penitenciária (SAP), em 14/10/2018. Disponível em: http://www.sap.sp.gov.br/uni-prisionais/hos.html\# 
que, antes de qualquer discussão dessa natureza, é imperativo entender que o combate à malha jurídico-psiquiátrica na qual os pacientes-detentos estão enredados não deve se ater apenas à substituição de espaços, mas ao enfrentamento de lógicas" (ibid:22).

A proposta de extinção dos manicômios judiciários em conformidade com o abolicionismo penal, portanto, ganha matizes mais complexos do que o fechamento de portas de entrada e alargamento das portas de saída. O tópico "7.5. Entre o dentro e o fora: o efeito porta giratória" (:53) do relatório mobiliza uma outra metáfora para expressar essa ideia de uma desinternação que, eventualmente, desemboca em uma ou mais reinternações posteriores.

Dito isso, antes de fazer as considerações sobre a metodologia e resumo dos capítulos que constituem a dissertação, julgo pertinente discorrer, ainda que superficialmente, sobre os HCTPs e algumas categorias médico-jurídicas que são importantes para o desdobrar dos assuntos a serem discutidos ao longo do trabalho.

\section{Os manicômios judiciários e a Reforma Psiquiátrica Brasileira}

Os HCTPs são instituições parte do sistema carcerário brasileiro que custodiam a figura do "louco infrator", sob o regime jurídico da medida de segurança. Em linhas gerais, a internação compulsória realizada nesses locais é baseada na noção de periculosidade do indivíduo, isto é, alguém que tenha cometido práticas análogas a crime, mas que, por ser considerado portador de transtornos mentais, não tem consciência do caráter delituoso do ato. Nesses casos, após avaliação pericial que pode ser solicitada por qualquer uma das partes do processo penal e cujo nome é incidente de insanidade mental, o réu pode ser considerado, de acordo com Decreto-Lei $\mathrm{n}^{\circ} 2.848$, de 7 de dezembro de 1940 - o Código Penal Brasileiro - semi-imputável ou inimputável, processo esse conhecido por absolvição imprópria. Isso significa que há uma absolvição da pena, esta assentada na ideia de culpabilidade e, em seu lugar, exara-se a medida de segurança. Uma vez determinada, o réu pode ser encaminhado compulsoriamente para tratamento ou em meio aberto (ambulatorial) ou fechado (internação), a depender da gravidade que o magistrado aferir ao caso (Barros, 2018; Matsuda, 2009). Não obstante a medida de segurança disponha de um período mínimo, podendo variar de um a três anos, cuja estipulação é exclusiva à vontade do juiz, não há um prazo máximo para seu término.

Embora a abordagem histórica tanto dos manicômios judiciários quanto das categorias médico-jurídicas extrapole o escopo desta dissertação, não há como dissociar 
o contexto de sua emergência com a atualidade. Isso seria obliterar como essas operações são reatualizadas na contemporaneidade, não sendo, portanto, apenas resquícios de uma outra época. Com efeito, as taxonomias da Escola Positiva de Direito Criminal não se fazem tão distantes quando se estudam processos jurídicos e laudos psiquiátricos do sistema de justiça e a antropologia criminal tem um papel preponderante nesse legado que se perpetua (Carrara, 1998; Lopes, 2014; Matsuda, 2009; Padovani, 2010, 2018).

Assim, como criações da passagem do século XIX ao XX no Brasil, os manicômios judiciários procuraram responder à demanda de infratores duplamente estigmatizados, pelo crime e pela loucura, que até então eram tratados por dois regimes distintos: a prisão para os "criminosos", e o hospício para os "loucos" (Carrara, 1998). São instituições, também, que são fruto de uma virada epistemológica da "loucura" no século XIX, cujos expoentes, dentre muitos da psiquiatria alienista em voga na época, são Benédicte Augustin Morel e Cesare Lombroso. Suscintamente, trata-se de um movimento tanto da psiquiatria quanto da antropologia criminal que deslocou a loucura enquanto uma doença contingente que acomete um indivíduo naturalmente sadio -“crime-doença” - em direção a uma natureza essencialmente corrompida, cuja epítome seria a categoria do degenerado - "crime-atributo" (Carrara, 1998:75). Enquanto a noção de monomania, nos moldes de uma patologia, teria um teor menos pessimista, visto que uma vez tratada o indivíduo poderia evoluir à condição considerada "normal", os degenerados ou criminosos natos surgem como seres incapazes de percorrem esse caminho, entendidos como uma condição crônica, em regressão irreparável. Ao longo desse período, portanto, o crime é menos entendido como desvio moral do que disfunção orgânica (Carrara,1998, 2010).

A noção jurídica de "periculosidade”, como aponta Fernanda Matsuda (2009), finca raízes históricas justamente na noção de "degeneração", uma vez "que tomou para si uma noção advinda do alienismo e passou a utilizá-la para definir políticas criminais" (Matsuda, 2009:19). Na atualidade, como argumenta a autora, não obstante o caráter fluido desse conceito, sua replicação permanece patente na interface entre Direito Penal e Medicina. É essa interface entre dois campos do saber que faz dos HCTPs locais híbridos de manicômio e prisão, operando sob as lógicas “jurídico-punitiva” e “psiquiátrico-terapêutica" (Carrara, 2010:19). Uma vez absolvido impropriamente, como se denomina na terminologia jurídica, o indivíduo é submetido a avaliações psiquiátricas anuais que visam constatar a cessação ou não de sua periculosidade. Enquanto esta não 
cesse, a custódia permanece e um indivíduo cujo crime receberia uma pena determinada, na consideração de imputabilidade, não raro é submetido a um tempo muito maior de reclusão quando comparado com o mesmo crime, porém com o pressuposto da semi ou inimputabilidade (Diniz e Brito, 2016).

No que diz respeito à Reforma Psiquiátrica no Brasil, cabe destacar, brevemente, que ela é fruto de uma longa luta antimanicomial protagonizada, sobretudo, por movimentos sociais e funcionários da seara de saúde mental, a qual vem tomando corpo desde, pelo menos, a década de 80 do século passado. Em 2001, houve, finalmente, a promulgação da Lei Federal 10.216, também conhecida como Lei da Reforma Psiquiátrica, cujo grande marco foi a passagem do modelo hospitalocêntrico para o de rede em meio aberto, graças à instauração da RAPS (Rede de Atenção Psico-Social), inaugurando equipamentos públicos de saúde, dentro da competência do SUS, entre os quais os CAPS (Centros de Atenção Psico-social) e oficinas e residências terapêuticas ${ }^{14}$. Nesse cenário, contudo, os HCTPs permaneceram à margem desse processo, indo na contramão da desinstitucionalização que se desenrolava a inícios do século XXI (Lhacer, 2013). Como procura pontuar o Relatório Hospitais-Prisão:

Contudo, se os motes primordiais dos movimentos ligados à luta antimanicomial pautavam justamente a desinstitucionalização, os tratamentos junto à comunidade e a reintegração sociofamiliar, a realidade existente nos manicômios judiciários evidencia um dos limites da Reforma Psiquiátrica, uma vez que tais espaços continuam mantendo pessoas encarceradas em ambientes degradantes, que atualizam a lógica manicomial (Relatório Hospitais-Prisão, 2018:21)

Feita essa breve contextualização dos manicômios judiciários tanto em interface com as políticas de saúde pública brasileiras quanto com sua trajetória histórica, passo para algumas considerações metodológicas, seguida da apresentação da estrutura da dissertação. Sublinho, no entanto, que as informações até aqui apresentadas serão reconduzidas em determinados momentos do texto de modo mais detido.

\section{Caderninhos e canetas: algumas considerações metodológicas}

Por serem instituições pertencentes ao sistema penitenciário, a entrada do GT nos manicômios judiciários enquanto grupo composto por agentes pastorais sempre esteve condicionada a algumas regras. Além da proibição ao uso de acessórios estéticos, tais como brincos, pulseiras, bem como de vestuário de igual tonalidade a pacientes-

\footnotetext{
${ }^{14}$ Para maiores informações sobre os primórdios da Reforma Psiquiátrica Brasileira, ver Amarante (1995) e Delgado (2011).
} 
detentos(as) ou agentes de segurança dos HCTPs, era-nos proibido o uso de máquinas fotográficas, gravadores e celulares. Desse modo, nossa principal ferramenta de trabalho no atendimento das demandas que nos chegavam eram nossos caderninhos e canetas (estas de corpo transparente e tinta de cor azul ou preta, não outra).

Como resultado, a experiência de visitas que veio a servir de base para a redação do relatório é tributária das inúmeras anotações e registros, tanto dessas demandas quanto do que víamos e ouvíamos desde a posição de agentes pastorais. Redigir o relatório coletivamente, portanto, implicou um árduo processo de compartilhamento $\mathrm{e}$ sistematização de nossos escritos, os quais foram reescritos e editados a fim de dar-lhes corpo no formato relatório. Esse processo durou em torno de seis meses.

Tal fato se faz importante de ser mencionado pois, tanto quanto ele, minha dissertação também é fruto das anotações do mesmo caderninho que usava para o registro de demandas e dos acontecimentos que o atravessaram durante meu trabalho de agente pastoral no período de, aproximadamente, dois anos (2016-2018). Por isso, entendo que longe de serem paralelas as minhas posições de agente pastoral e etnógrafo, as fronteiras entre elas acabaram nubladas e sobrepostas uma vez que o que era visto e ouvido nos HCTPs, bem como os demais acontecimentos que me implicavam enquanto membro do GT, foram também a fonte de escritos para esta dissertação.

Como dizia anteriormente, ser parte da PCr implica, frequentemente, ser algo além em concomitância, e os(as) pesquisadores(as) não constituem exceção. Com efeito, muitos trabalhos acadêmicos de extrema relevância a respeito do sistema carcerário tiveram também como base, respeitando as devidas diferenças temáticas e metodológicas, posições institucionais outras desses(as) pesquisadores(as), inclusive como agentes pastorais, mas também como pertencentes a outras organizações civis que têm o sistema carcerário como foco de atuação. Apenas a título de referência, cito os trabalhos de Antunes (2017), Bumachar (2016), Godoi (2015), Lago (2014), Mallart (2018), Padovani (2015), Zamboni (2017).

Dado esse delicado imbricamento, embora o Relatório Hospitais-Prisão seja um eixo norteador desta dissertação, sobretudo no que diz respeito ao seu processo de produção e lançamento, ele não o será separadamente de outras fontes que lhe deram base, sendo meu caderninho uma delas. Nesse sentido, optei por não realizar nenhum tipo de entrevista durante a pesquisa, transformando tanto as anotações nos e sobre os HCTPs 
quanto aquelas feitas em outros contextos - encontros e assembleias da $\mathrm{PCr}$, reuniões do GT, bem como de eventos com participação da $\mathrm{PCr}$ - em dados etnográficos. Além desses momentos, os documentos também foram fonte de material para a etnografia, tanto aqueles produzidos pela PCr, tal como o Relatório Hospitais-Prisão e demais relatórios, bem como cartilhas e notas de repúdio, quanto os processos de execução penal de disponibilidade pública e os laudos psiquiátricos, estes alocados na $5^{\text {a }}$ Vara de Execução Criminal (VEC) da capital paulista, localizada no Fórum Criminal da Barra Funda. A respeito dos documentos enquanto "peças etnográficas", creio que a citação de Adriana Vianna sintetiza o olhar analítico que darei aos muitos papeis referenciados ao longo desta dissertação:

\begin{abstract}
Defendo, assim, que levar a sério os documentos como peças etnográficas implica tomá-los como construtores da realidade tanto por aquilo que produzem na situação da qual fazem parte - como fabricam um "processo" como sequência de atos no tempo, ocorrendo em condições específicas e com múltiplos e desiguais atores e autores quanto por aquilo que conscientemente sedimentam. Quando digo conscientemente não suponho intenções pré-fabricadas, mas tão somente a presença constante dos constrangimentos que the são inerentes como documento: algo que selará um destino, sob a forma de sentença final; que ficará arquivado, podendo ser consultado, mediante condições específicas, por diferentes atores em diferentes momentos; que exige daqueles que produzem, alinham e acumulam seus fragmentos o compromisso com o efeito de coerência que deve ser sentido em seu conjunto. Sua obrigação presumida de ser algo que deve permanecer e durar, dada, antes de mais nada, por seu caráter de "documento", percorre, desse modo, todo seu processo de confecção e seus múltiplos e variados tempos (Vianna, 2014:47).
\end{abstract}

\title{
Abolicionismo penal: uma prática de contar e rememorar histórias
}

Ao abrir a homepage da PCr, o primeiro a saltar aos olhos é a imagem de uma sequência de velas acesas contra um fundo escuro sob o título Massacre em Manaus: Relatos e Histórias. Ao clicarmos na imagem, abre-se uma página com a seguinte ementa: "A Pastoral Carcerária Nacional tem acompanhado, prestado solidariedade e ajuda às familiares e à Pastoral Carcerária de Manaus após o massacre ocorrido nas prisões. Nesta página, compilamos relatos das familiares e notícias sobre como está a situação no Estado, para que esse episódio jamais seja esquecido" (ênfase minha). Abaixo dela, uma sequência de vídeos com depoimentos de mulheres, cada qual encabeçado por uma única frase que foi por elas dita: "Eles sabiam que um massacre ia acontecer" e "O Estado tem que parar de matar nossos filhos" são dois exemplos dos cinco vídeos disponíveis ${ }^{15}$.

\footnotetext{
15 Vide: https://carceraria.org.br/combate-e-prevencao-a-tortura/massacre-em-manaus-relatos-e-
} historias 
A ementa da página virtual faz referência ao quinto de seis massacres ocorridos, desde 2017, em presídios da região norte e nordeste do Brasil, tendo esse em questão ocorrido em 27 de maio de 2019 no Complexo Penitenciário Anísio Jobim (Compaj), localizado em Manaus. Como vemos, além da menção da atuação da PCr Nacional junto às familiares e à PCr estadual, são disponibilizados "relatos" e "histórias" das pessoas que sofrem pelos seus, justificando essa iniciativa através de um imperativo de rememoração. Seja através do texto com citações diretas ou dos recursos audiovisuais, sugere-se a importância da veiculação ou transmissão de "histórias", colocando a PCr numa função de mediação entre rementes e destinatários. Tal importância parece ressoar com o texto de apresentação da PCr, disponível em sua homepage citado no início desta introdução, no qual se destaca que "os/as agentes pastorais promovem um serviço de $\operatorname{escuta}(\ldots) "$.

De fato, em minha experiência como agente pastoral foram inúmeras as vezes que ouvi a descrição do trabalho de assistência religiosa como um trabalho "de escuta". A palavra "história", contudo, não veio à tona até que eu a encontrasse redigida no incidente de insanidade mental de Mercedes, uma das pacientes-detentas com quem tive contato e cujo documento redigido por um perito psiquiátrico é citado pelo juiz que julgou o seu caso para outorgar-lhe sua sentença. Na citação, consta que a ré apresenta "sinais, história e sintomas compatíveis com moléstia mental parcialmente alienante" (ênfase minha). Intrigou-me, então, que um distúrbio mental pudesse ser diagnosticado não apenas com base na identificação de sintomas ou outros indicadores biológicos, mas também a partir de uma determinada "história".

Embora esse caso seja objeto de análise no capítulo 3 da dissertação, acredito que tanto a ementa do website quanto o laudo de Mercedes ilustram o ponto principal a que me proponho discutir. Se o abolicionismo penal é o eixo norteador da $\mathrm{PCr}$ e as visitas cotidianas, como um "serviço de escuta", são uma atividade chave da organização, pergunto: como as histórias ouvidas no sistema carcerário ganham ressonância e em que medida transmitir histórias se relaciona com a construção de "um mundo sem cárceres"? No que concerne ao GT, como as histórias ouvidas nos seus quatro anos de existência e grafadas apressadamente em nossos caderninhos são reescritas no Relatório HospitaisPrisão e quais as implicações políticas dessa transcrição de escuta em escrita? O que se perde e o que se ganha nesse processo e como ele contribui para a extinção de manicômios judiciários em sintonia com o abolicionismo penal? Cotejar a ementa da $\mathrm{PCr}$ com o 
incidente de insanidade mental de Mercedes, portanto, tem como objetivo provocar o questionamento de que contar histórias, e as formas pelas quais as contamos, são ações inexoravelmente políticas e, não raro, eivadas de contrassensos, embora nem sempre as vejamos como tal.

No capítulo 1, A tentativa de "escutar" histórias, procuro introduzir os pressupostos teológico-morais sobre os quais a PCr se assenta, notadamente a premência dessa escuta como mote do trabalho pastoral. Nessa chave, pretendo também colocar em perspectiva as diferentes concepções morais subjacentes ao ato de escutar pelos agentes pastorais, mostrando como essa multiplicidade foi motivo de tensões e fraturas de instâncias da PCr e, mais especificamente, do GT. Almejo, igualmente, problematizar os limites e contradições a que está conformada uma relação de assistência religiosa em ambientes prisionais-manicomiais, interpelando como essa relação visibiliza ou oblitera as desigualdades que lhe são imanentes e como tais clivagens interferem na transmissão de histórias.

No capítulo 2, A tentativa de "escrever" histórias, ajusto o foco para como se deu o processo de escrita do Relatório Hospitais-Prisão, o qual, por sua vez, foi baseado nas várias escritas dos caderninhos de membros(as) do GT. A fim de cumprir esse objetivo, discuto como o conteúdo do documento foi pautado pela construção de um sentido de "tortura" que conceituasse a operação dos HCTPs como violadora, embora diretores e funcionários respaldassem suas funções profissionais por imperativos morais de cuidado e provimento de saúde à população custodiada. Analisando esse investimento semântico, proponho que o GT não deixava de operar com imperativos, que, não obstante distintos, eram também balizadores morais de sua atuação religiosa-humanitária. Como transformar o que foi ouvido e visto, isto é, as várias histórias com as quais nos envolvemos em escrita de modo a propugnar politicamente pela extinção dos HCTPs será o ponto central de discussão.

Finalmente, no capítulo 3, Abolicionismo penal como histórias sem inícios e fins, atenho-me a um caso em específico com o qual me defrontei enquanto agente pastoral. Trata-se do caso de Mercedes, em que me envolvi na tentativa, a seu pedido, de evitar que seu filho Marcos fosse adotado mediante um processo de destituição familiar que corria contra sua vontade. Meu enfoque será discutir como o próprio trabalho pastoral é também um meio pelo qual procuramos agir em histórias, para além de somente contá- 
las. Argumento que, como esse caso me mostrou, determinadas demandas motivadas por um trabalho penal abolicionista às vezes requerem parcerias e relações com o Estado, muito embora seja um trabalho que se identifique como contra. Em suma, interpelo o quanto "um mundo sem cárceres" está inserido em relações que também dependem do Estado e com ele estabelece parcerias, ainda que contingenciais, para a solução de demandas. O imprevisto dos enredos e os finais sempre abertos dessas histórias dão pistas sobre como a diretriz abolicionista penal é sempre inacabada e com rumos que, raramente, estão sob nosso controle.

Na última seção, A Antropologia e o Abolicionismo penal como "histórias-atéagora" que contam histórias: para onde nos levam as etnografias?, provoco uma reflexão desta dissertação como uma tentativa também de contar histórias, escolhendo a escrita como forma política de análise e veiculação de muitas histórias ouvidas e grafadas, incluindo a história do próprio Relatório Hospitais-Prisão. Ao fazê-lo, implico, necessariamente, o meu caderninho de anotações de demandas, o qual era, concomitantemente, meu caderno de campo, e parte da história da ciência antropológica. Dito de outro modo, quais as interfaces possíveis entre essas diferentes escritas que, de algum modo, tem como denominador comum o "contar histórias" e qual a relação com o legado colonialista da antropologia? É possível que a escrita antropológica possa aspirar ser uma escrita abolicionista penal?

Como último apontamento, esclareço algumas questões do formato desta dissertação: todos os nomes apresentados são fictícios a fim de preservar o anonimato de meus interlocutores. Citações de documentos, sejam virtuais ou físicos, são designadas em itálico e aspas. Já para as citações orais, bem como para citações e conceitos acadêmicos optei pelo emprego de aspas somente. 


\section{Capítulo 1: A tentativa de "escutar" histórias}

Unlike a sketch that may be executed on a different scale from the final picture one draws, or what may lack all the details of the picture but still contain the imagination of the whole, the fragment marks the impossibility of such an imagination. Fragments allude to a particular way of inhabiting the world, say, in a gesture of mourning (Das, 2007:5)

Neste primeiro capítulo, procuro discutir como o trabalho pastoral pautado pelo abolicionismo penal assenta-se sobre o que chamo de embasamentos teológico-morais, que são mote de seu lema "Por um mundo sem cárceres". Veremos que a recorrente designação desse trabalho como "pastoral da escuta" é peça chave para entendê-lo a partir da importância do "testemunho" de contextos adversos a fim de que as histórias ali ouvidas e grafadas ganhem ressonância em outros espaços. Entretanto, devido à diversidade de atores aglutinados sob a instituição, veremos também como diferentes concepções do que deve ser essa escuta, não raro ocasionaram atritos e fraturas entre grupos e instâncias pertencentes à Pastoral Carcerária.

Inicio fazendo uma breve contextualização do lançamento do Relatório HospitaisPrisão: Notas sobre os manicômios judiciários de São Paulo (doravante Relatório Hospitais-Prisão), enfocando-o como um produto de muitas escutas que foram coletadas pelo Grupo de Trabalho Saúde Mental e Liberdade (GT) da PCr da Arquidiocese de São Paulo em seus quatro anos de existência. Em sequência, detenho-me sobre os motivos, expostos no lançamento, responsáveis pela escrita desse documento em interface com a atuação da PCr no sistema carcerário brasileiro.

Tendo esse cenário como pano de fundo, procuro argumentar que a diretriz política do abolicionismo penal propugnada pela $\mathrm{PCr}$ norteia, sobretudo, um trabalho cotidiano de escutar histórias consideradas silenciadas. Nesse sentido, o objetivo futuro de "um mundo sem cárceres" mobiliza uma temporalidade em que a linearidade não é o fio guia. Antes que o resultado de um possível fechamento de prisões, tal objetivo não se faz dissociado da construção desse "mundo sem cárceres" no presente, no plano cotidiano, no qual o trabalho de visitas às unidades penitenciárias é apenas um dos exemplos de atuação institucional da PCr. 


\section{O instável tripé do "ver-julgar-agir"}

Dia 16 de agosto de 2018. Depois de inúmeros contratempos e muitas tensões, o Relatório Hospitais-Prisão seria finalmente lançado. Naquela noite, ao contento de ver o auditório cheio, somava-se a ansiedade de apresentarmos ao público o trabalho que procurava ser o acúmulo de quatro anos de experiência de visitas aos Hospitais de Custódia e Tratamento Psiquiátrico (HCTP) paulistas, realizadas pelo GT $^{16}$.

$\mathrm{Na}$ mesa de abertura, contaríamos com a presença do coordenador nacional da $\mathrm{PCr}$, que era também, à época, coordenador da $\mathrm{PCr}$ a nível latino-americano e arquidiocesano de São Paulo, com o representante da Associação de Amigos e Familiares de Presos (AMPARAR) e também representante do Movimento Negro Unificado (MNU), com o coordenador do Núcleo de Especializado de Situação Carcerária da Defensoria Pública do Estado de São Paulo (NESC- DP/SP) e com a professora da Pontifícia Universidade Católica (PUC), da área de psicologia social e especialista em saúde mental e sistema carcerário. Como representantes do GT, estaria eu e uma colega, que, juntos, faríamos a abertura do evento, fazendo uma breve fala de contextualização do Relatório Hospitais-Prisão em interface com o trabalho da $\mathrm{PCr}$ e o histórico do GT como um grupo vinculado à organização a nível arquidiocesano.

Sem querer fazer um repasse detalhado de como foi o referido evento, pretendo apenas destacar a forma como os representantes da PCr fizeram a apresentação e justificativa da redação do relatório. Primeiramente, o coordenador nacional abriu a mesa situando o relatório no âmbito de ação da PCr. Ele ressaltou que a organização tem um "compromisso com a pessoa privada de liberdade", mas que não se limita a ela, uma vez que compartilha, com outras Pastorais Sociais, "um trabalho junto aos que mais sofrem e padecem”, sensível a "um olhar para a população à margem da sociedade”. Em seguida, destacou que a Igreja já tinha se atentado à população em sofrimento mental quando, em 1995, o tema da Campanha da Fraternidade foi "A fraternidade e os excluídos"17. Esse teria sido o gatilho para a criação, no início dos anos 2000, de um grupo dentro da PCr da arquidiocese de São Paulo reunindo agentes pastorais, acadêmicos das áreas de psicologia e ciências sociais e membros da Secretaria de Administração Penitenciária (SAP), a fim

16 A gravação em vídeo do lançamento do Relatório Hospitais-Prisão pode ser acessada, na íntegra, em: https://www.facebook.com/PastoralCarcerariaCNBB/videos/296405651165034/

17 Segundo a explicação do coordenador nacional, A "Campanha da Fraternidade" é uma campanha anual realizada pela Confederação Nacional dos Bispos no Brasil (CNBB). Com um tema diferente a cada ano, o principal objetivo é conclamar fiéis do catolicismo à reflexão sobre um tema em particular, incentivando a busca de soluções através da implementação de políticas públicas. 
de realizar um trabalho específico com a população custodiada nos HCTPs. Por diversos motivos, como continuou a explicação, o grupo deixou de existir até que, em 2014, um novo fôlego emerge para a retomada desse trabalho, mantendo seu caráter interinstitucional, porém, dessa vez, sem representatividade da SAP e com participação da Defensoria Pública de São Paulo, criada em $2006^{18}$. Finalmente, no que diz respeito ao relatório, retomou o "compromisso [ $\mathrm{da} \mathrm{PCr}$ ] com essa realidade" dizendo que o documento é "esse olhar da PCr que tenta escutar, visitar, estar presente", sendo também a tentativa de "colocar o debate do fim do sistema prisional", do qual os HCTPs são parte.

Chegado nosso momento de fazer as considerações como representantes do GT, eu e minha colega centramos nossa fala na estrutura do texto do relatório e quais foram suas fontes. Em primeiro lugar, destacamos que nosso ponto de partida foi "a narrativa dos internos" e aquilo que vimos e escutamos visitando periodicamente os HCTPs, "priorizando relatos tradicionalmente silenciados pelos muros prisionais", uma vez que a PCr é "essencialmente uma pastoral da escuta". Na sequência, um destaque da razão que faz da "narrativa" um ponto importante: "muito do que eles têm como possibilidade para serem ouvidos é a palavra, então estamos aqui para transmitir essa palavra que a gente ouviu nesse tempo". Um dos aspectos que fazem dessa transmissão uma tarefa importante, como continuamos dizendo, é que ela seja ouvida pelos "atores competentes" para a averiguação e julgamento de violações de direitos humanos nessas instituições, entre os quais o juízo da execução penal, e a DP-SP, esta última, como dito, presente na mesa de lançamento. Por fim, concluímos que por não ser o primeiro material produzido a respeito dos HCTPs ou do sistema prisional brasileiro em sentido mais amplo, procurávamos buscar "ressonâncias" com outros relatórios e outros atores atuantes, referenciados no corpo do texto.

\section{Um sobrevoo pela Doutrina Social da Igreja}

A ideia de que o Relatório Hospitais-Prisão é "um olhar que tenta escutar" e "estar presente" sugere a interrelação entre um documento e uma moralidade basilar do trabalho pastoral. Além disso, a importância dessa interrelação não parece se circunscrever ao documento em si, na medida em que a "ressonância" com outros papeis se faz um fundamental elemento de legitimidade de sua redação. Com efeito, ademais do

\footnotetext{
${ }^{18}$ Cabe destacar que a PCr, juntamente com outros movimentos sociais, foi um dos atores a exigir a criação da defensoria pública de São Paulo, fato que veio a se concretizar em 2006.
} 
referenciamento a outros relatórios de cunho denuncista, no prefácio do material, escrito pelo coordenador nacional, está clara a intenção de vincular o relatório a uma série de documentos eclesiais que o precederam. Cito:

O lema da Pastoral Carcerária está no Evangelho: "Estive preso e vieste Me visitar". No mesmo capítulo 25 de Mateus, Jesus afirma: "Cada vez que o fizestes a um desses meus irmãos mais pequeninos, a Mim o fizestes". Isso implica encontrar a face de Jesus no rosto de cada excluído: é o próprio Jesus quem está preso, marginalizado e maltratado pela sociedade.

Tendo isso como pedra fundamental de seu trabalho, a Pastoral Carcerária tem o compromisso com a defesa da vida e da dignidade das pessoas consideradas portadoras de transtornos mentais que se encontram depositadas em Hospitais de Custódia e Tratamento Psiquiátrico e, alarme-se, no sistema prisional comum.

A Igreja não se omite frente a essa realidade e nos ensina que "todo processo evangelizador envolve a promoção humana" (CELAM, 2007). Neste sentido, convoca todas as pastorais e membros das comunidades a julgarem a realidade à luz da fé, tendo em conta a Palavra de Deus, o Magistério e a Doutrina Social da Igreja.

É em atenção a esse chamado de Cristo e da Igreja que se constituiu o Grupo de Trabalho (GT) "Saúde Mental e Liberdade" da Pastoral Carcerária da Arquidiocese de São Paulo, que atua em ambiente de confinamento de pessoas provenientes de uma realidade marcada pela pobreza, desigualdade, preconceito, discriminação, injustiça e exclusão (Relatório Hospitais-Prisão, 2018:9).

Convido o(a) leitora(a) a uma breve digressão a respeito da Doutrina Social da Igreja, mencionada nos parágrafos acima. $\mathrm{O}$ conjunto de documentos e pronunciamentos agrupados nessa nomenclatura são importante sustentação teológico-pastoral-doutrinária de experiências católicas na América Latina, entre as quais as Pastorais Sociais e Comunidades Eclesiais de Base (CEB).

No trecho citado acima, além da referência bíblica que constitui o lema da organização, há a referência à V Conferência Geral do Episcopado Latino-Americano e do Caribe (CELAM) em 2007 na cidade de Aparecida, Brasil. A Carta de Aparecida, como ficou conhecido o documento produzido nessa conferência, reafirmou as diretrizes acordadas nas conferências de episcopado anteriores (Conferências de Medellín [1968] e de Puebla [1979]), notadamente a "opção pelos pobres" (Documento de Aparecida, 2007:399). Reconsagrou, igualmente, uma “caminhada" de Igreja na qual a Declaração Universal dos Direitos Humanos é incorporada como "parte indispensável da sua missão evangelizadora" (Gaudium et Spes, 71 apud Cartilha $\mathrm{PCr}^{19}$ ). "Evangelizar", tal como defendido no texto de apresentação do Relatório Hospitais-Prisão e a partir desses

19 “Cartilha PCr" é a nomenclatura sintetizada da Cartilha Formação para agentes da Pastoral Carcerária (2014), elaborada pelo Escritório Nacional da PCr. 
referenciais, adquire uma conotação semântica que repudia uma postura estritamente doutrinária, apelando para um sentido de se fazer ativamente presente junto a minorias, tendo em perspectiva a

promoção da vida e a recusa de tudo o que agride a criação divina, incluindo os sistemas ideológicos que submetem as pessoas mais vulneráveis às classificações arbitrárias e violentas de suas identidades e subjetividades (Relatório Hospitais-Prisão, 2018:10).

Definir-se como Pastoral Social, portanto, é um processo indissociável da referência a um amplo repertório documental, do qual a bíblia é a base em sentido teológico e programático, isto é, como imprescindível referência que, através da espiritualidade, informa a ação no plano concreto. Significa também dialogar com documentos não estritamente teológicos, como a Declaração Universal dos Direito Humanos, ressaltando como seus ditames se costuram com preceitos de "evangelização" sob um determinado enfoque que faz de aspectos político-sociais condição imprescindível do que se entende por religião.

Suscintamente, então, as Pastorais Sociais constituem ações eclesiais para além dos muros da Igreja, nomeando-se, como ouvi frequentemente, "pastorais de fronteira" ou "Igreja em Saída", tendo como sustentação um cristianismo engajado social e politicamente na realidade, o que concretamente significou, nas suas origens, o alinhamento com "a caminhada" de movimentos sociais de esquerda e a formação de alianças entre eles e comunidades populares por meio das CEBs.

As pastorais sociais ganharam proeminência, na América Latina, principalmente em meados das décadas de 60 e 70 do século $\mathrm{XX}^{20}$, períodos esses nos quais as Conferências de Medellín (1968) e de Puebla (1979) são importantes marcos. Como II e III Conferências Geral do Episcopado Latino Americano, respectivamente, lá foram firmados princípios, literalizados nas Cartas que levam o nome dos dois encontros. Ambas advogam por uma renovação da Igreja a favor dos pobres e marginalizados da sociedade em um contexto fortemente influenciado pela ascensão de governos ditatoriais na América Latina (Rufino, 2013). O significado de libertação mobilizado, tendo o autoritarismo político como pano de fundo, estava fortemente aportado numa interface

${ }^{20}$ As pastorais sociais, tal como as conhecemos hoje, ganharam forma somente a partir da década de 70. Na década anterior, houve a constituição das Ações Católicas Especializadas, que podem ser definidas como precursoras das pastorais sociais. Eram elas, à época, a Juventude Agrária Católica, a Juventude Estudantil Católica, a Juventude Independente Católica, Juventude Operária Católica e Juventude Universitária Católica. 
com as ciências sociais e filosofia, interface essa na qual o marxismo foi uma importante influência. Esse repertório epistemológico foi essencial para consolidar um olhar estrutural, menos relacionado com uma superação individual do pecado, do que a busca da liberdade frente a tudo que é fonte de opressão. É ilustrativo, nesse sentido, o excerto de texto publicado no website da PCr nacional e que procura celebrar, em 2019, os 40 anos da Conferência de Puebla:

\begin{abstract}
"A Igreja condena aqueles que tendem a reduzir os espaços da fé à vida pessoal ou familiar, excluindo a ordem profissional, econômica, social e política, como se o pecado, o amor, a oração e o perdão não tivessem aí relevância". É por isso que a situação de miséria, marginalização, injustiça e corrupção, que fere o continente latino-americano, exige do Povo de Deus e de cada cristão um autêntico heroísmo no seu compromisso evangelizador, para que se possa superar tão grandes obstáculos $^{21}$
\end{abstract}

Mais do que um conjunto de princípios, porém, as Conferências Gerais de Episcopado reatualizaram a centralidade do que ficou conhecido como o método "verjulgar-agir”. Idealizado inicialmente pelo sacerdote belga Joseph Cardjin (1882-1969), seu engajamento de base teológica, sintetizado nessa metodologia, não só articulou movimentos de jovens operários do início do século XX na Europa, sendo fundador da Juventude Operária Católica, como perpassou o Concílio Vaticano II de 1961, fincando raízes em documentos e pronunciamentos eclesiais desde então, incluindo a exortação Evangelli Gaudium do Papa Francisco, de 2013 (Ferreira, 2016).

Esses três verbos vieram à tona durante minha experiência enquanto agente pastoral em vários momentos, mas destaco sua presença na Cartilha $\mathrm{PCr}$, elaborada pelo Escritório Nacional da PCr e que condensa, de maneira didática, os principais referenciais documentais eclesiásticos em interface com a "missão" da PCr. Nesse livreto, os verbos "ver", "julgar" e "agir", respectivamente, dividem os tópicos abordados em três grandes seções, permeados de citações e referências a uma miríade de documentos eclesiásticos.

De modo geral, essa metodologia prevê um catolicismo que se transforme em ação, a partir de três passos. O primeiro deles, em consonância com a proposta da Campanha da Fraternidade, é o "ver", que "visa de maneira indutiva refletir sobre a realidade e seus problemas, discernindo-a em vistas de uma ação concreta". Subsequentemente, viria o "julgar", que consiste no encontro entre o que se é visto com o estudo do evangelho católico a fim de que se produza um julgamento sobre a "realidade"

${ }^{21}$ Para ver o texto na íntegra, acessar: https://carceraria.org.br/igreja-em-saida/puebla-igreja-apartir-dos-pobres?fbclid=IwAR1QgtDsyhXsS35g403aHyED9tJw8BulODw0RkJL1Kj8 dpiprN0iP-QtzQ 
para, finalmente, construir ações ("agir") efetivamente transformadoras da realidade social, não restritas a um viés puramente caritativo (Ferreira, 2016:218).

A indissociabilidade entre teoria e ação/política e religião, portanto, formam o ângulo de dobra em que o trabalho pastoral se fundamenta. Fazendo referência às conclusões da Conferência de Medellín, a Cartilha PCr ressalta:

\begin{abstract}
Lutar pelos direitos humanos não é tarefa fácil. Inclusive, há muitos preconceitos e distorções quanto ao que é essa luta. Mas é tarefa necessária e prioritária. A Igreja, com profetismo e coragem, assume o desafio consciente de que essa caminhada também promove incômodo e mexe com os privilégios de determinadas camadas da sociedade, mas sabe que evangelizar é, também, estar com o povo (Cartilha PCr, 2014, p.15, grifo meu).
\end{abstract}

Conjugo o excerto acima com outro parágrafo do texto de apresentação, escrito pelo coordenador nacional, do Relatório Hospitais-Prisão:

\begin{abstract}
A passagem de $\mathrm{Fl}$ 2, 6-8 exprime que Jesus Cristo "estando na forma de Deus" tornou-se "semelhante aos homens e reconhecido em seu aspecto como um homem". Isto posto, por meio da Encarnação do Verbo, Jesus assume a condição humana - comportando também as suas fraquezas e limitações - para cumprir o plano salvador de Deus. Assim, Ele também foi categorizado, estigmatizado e criminalizado, assim como os pequenos e excluídos de outrora e de hoje (Relatório Hospitais Prisão,2018: 10, grifo meu).
\end{abstract}

A proposição de "evangelizar" como "estar com o povo" exorta um profetismo comprometido com a presença, convidando-nos, tal como foi Jesus, a ser "encarnação do verbo" entre os "excluídos de outrora e hoje". Essa palavra-presença, assentada nos entremeios da religião e política/teoria e ação é a pedra de toque do que é nomeado pela PCr como "testemunho" e parece estar no cerne desse "olhar que tenta escutar, estar presente", a fim de que as "narrativas silenciadas pelos muros prisionais" ganhem "ressonância".

No próximo tópico, pretendo colocar em perspectiva como se dava essa prática de "escutar, estar presente" a partir do relato etnográfico de uma experiência de visita, realizada pelo GT, a um dos HCTPs de Franco da Rocha.

\title{
Quando documentos brigam: a "parte social" vs "parte religiosa
}

Como de praxe, estávamos um pouco atrasados para aquela visita. $\mathrm{O}$ ponto de encontro era a estação de trem da CPTM de Franco da Rocha. De lá, seguiríamos de 
carona no carro de uma das membras do GT, que estaria nos esperando às 9 h00 logo diante da estação.

Reunimo-nos na saída da catraca enquanto esperávamos a chegada daqueles que haviam confirmado presença para aquela visita e cujos nomes, seguidos de R.G já constavam no ofício que havia sido enviado uma semana antes, conforme requisitado pela $\mathrm{SAP}^{22}$. Se era fato comum que uma certa ansiedade precedia nossas visitas, nessa visita em particular estávamos um pouco mais apreensivos devido ao que ocorrera na visita anterior. Quinze dias antes, quando duas membras do GT chegaram na diretoria, primeiro ponto de parada para que anunciemos ao diretor nossa chegada, sua entrada às instalações fora interditada com a alegação de que o ofício não havia sido enviado e, por conseguinte, não estavam autorizadas a entrar. Embora houvessem insistido o contrário, inclusive com a tentativa de mostrá-lo na tela do celular de uma delas, o diretor foi inflexível, argumentando ainda que manipular o celular em instituição prisional era considerado ato criminoso. Como resultado, a visita não foi realizada.

Não obstante raramente todos(as) do GT se fizessem presentes para visitas, principalmente por questões de agenda, naquele dia contávamos com um número expressivo de pessoas, mas que já não expressava sua diversidade constitutiva quando comparado à sua gênese. Como dito, o GT foi fundado em 2014 e, desde seu surgimento, foi marcado pela diversidade dos seus componentes. Quando de minha entrada ao GT, em 2016, a heterogeneidade do grupo, apesar da saída e entrada de alguns membros, era não só sua marca patente como disparadora de tensões entre nós, sobretudo pelo fato de a teologia católica não ser balizador comum de sua atuação, não obstante sua vinculação à PCr a nível arquidiocesano. Em meados de 2017, contudo, essa tensão desembocou na cisão do grupo em dois: os agentes religiosos que estavam há mais tempo visitariam em semanas alternadas aos membros que, a despeito de sua igual identificação como agentes pastorais, não compartilhavam da liturgia católica da mesma forma. Naquela visita, portanto, estava acompanhado de colegas do grupo a quem nos era atribuída a identificação de "parte social”, tanto por algumas instâncias da PCr quanto pelos HCTPs. Junto conosco, estava um padre que decidiu participar dos dois grupos ao mesmo tempo,

22 Até então, diferentemente das unidades prisionais comuns para as quais se apresenta uma carteirinha, emitida pela SAP, autorizando a entrada como "assistente religioso", nossa entrada era garantida pelo envio de ofícios à diretoria dos HCTPs, tarefa essa realizada pelo Escritório Estadual da PCr, sempre com uma semana de antecedência. Em 2017, no entanto, foi implementada uma política de carteirinhas para os HCTPs, emitidas pela Coordenadoria de Saúde da SAP, instância à qual os HCTPs estão subordinados. 
fazendo com que sua presença nos HCTPs fosse semanal, porém cada semana com um grupo diferente, ainda que ambos continuassem se identificando como PCr.

Estacionamos o carro na frente de um dos portões de entrada para a tradicional revista do porta-malas, realizada pelo agente de segurança da portaria, e a entrega de nossos documentos, que nos são costumeiramente devolvidos na saída. Feito isso, seguimos com o carro por uma estreita rota de paralelepípedos margeada por densa arborização, uma vez que o HCTP está localizado em meio à reserva ambiental do Juquery, a alguns quilômetros do centro da cidade. Aos poucos, divisamos à direita os primeiros pavilhões: prédios térreos com átrios internos de arquitetura que parece remeter a inícios do século XX, vistos através de elevadas grades metálicas com torres de observação localizadas nos vértices do perímetro gradeado quadrangular que contorna as construções e em cujo topo percorre uma cerca de arame estilo ouriço. À esquerda do caminho de pedra, uma relativamente pequena construção, também térrea, onde está alocada a diretoria e parte da administração.

Aguardando na antessala da diretoria, vejo o quadro de avisos em que se é possível ler um cartaz da SAP, cujo título é "um olhar amigo: prevenção ao suicídio”; em seus dizeres, era destacada a importância de sensibilizar-se "para com o próximo", antes que fosse “tarde". Além desse, pude ver a citação íntegra do salmo $91^{23}$ e também a seguinte frase: “Obrigado Deus pela casa que me protege da chuva, pela coberta que me esquenta do frio, pela comida que me tira a fome, pelo trabalho que me sustenta, pela família que me ama e pela proteção divina de todos os dias!!".

Convidados a entrar pela vice-diretora, sentamo-nos diante da mesa do diretor esperando que fosse começar a conversa repreendendo-nos pelo conflito que se passara na visita anterior. Para nossa surpresa, porém, o assunto não foi trazido à tona e, imediatamente após os primeiros "bons dias", partiu para os "importantes" avisos. O

23 “Aquele que habita no abrigo do Altíssimo e descansa à sombra do Todo-poderoso pode dizer ao Senhor: Tu és o meu refúgio e a minha fortaleza, o meu Deus, em quem confio. "Ele o livrará do laço do caçador e do veneno mortal. Ele o cobrirá com as suas penas, e sob as suas asas você encontrará refúgio; a fidelidade dele será o seu escudo protetor. Você não temerá o pavor da noite, nem a flecha que voa de dia, nem a peste que se move sorrateira nas trevas, nem a praga que devasta ao meio-dia. Mil poderão cair ao seu lado, dez mil à sua direita, mas nada o atingirá. Você simplesmente olhará, e verá o castigo dos ímpios. Se você fizer do Altíssimo o seu refúgio, nenhum mal o atingirá, desgraça alguma chegará à sua tenda. Porque a seus anjos ele dará ordens a seu respeito, para que o protejam em todos os seus caminhos; com as mãos eles o segurarão, para que você não tropece em alguma pedra. Você pisará o leão e a cobra; pisoteará o leão forte e a serpente. "Porque ele me ama, eu o resgatarei; eu o protegerei, pois conhece o meu nome. Ele clamará a mim, e eu lhe darei resposta, e na adversidade estarei com ele; vou livrá-lo e cobri-lo de honra. Vida longa eu lhe darei, e lhe mostrarei a minha salvação. " (Salmos 91:116) 
primeiro deles dizia respeito à chegada de antigos "pacientes" do HCTP, oriundos da Penitenciária III de Franco da Rocha (PIII), unidade penitenciária inteiramente masculina que opera alas psiquiátricas em dois de seus pavilhões ${ }^{24}$. Devido à ocorrência de uma rebelião nesse HCTP, em outubro de 2016, cujo incêndio destruiu o maior pavilhão masculino da unidade, houve a transferência massiva de pacientes-detentos $^{25}$ para a PIII, o que seria o contrafluxo do que se opera à nível ordinário, isto é, da PIII para o HCTP e não o contrário.

Ocorre que, à altura dessa visita, o pavilhão que fora inutilizado já se encontrava parcialmente reformado, permitindo que houvesse a realocação de um determinado contingente de pacientes-detentos em um dos seus setores. Isso também seria possível graças à transferência de contingente populacional para os outros dois HCTPs do estado e algumas desinternações com encaminhamento terapêutico para Centros de Atenção Psicossocial (CAPS), fatores esses que haviam acrescido o número de vagas disponíveis.

Segundo ele, nossa importância nesse cenário residiria na nossa contribuição "social" aos "pacientes", que comumente chegavam "estressados" da PIII. Eles chegariam em levas de dez por semana a partir do mês seguinte e, reforçando a importância de nossa presença, sublinhou a importância de estarmos "sensíveis" aos reingressantes, aos quais se somavam também novos "pacientes".

Seu comentário era, no mínimo, inusitado, uma vez que a "parte social” era justamente o problema com que devíamos nos confrontar de maneira recorrente nas visitas. A razão para isso era que o trabalho de resolução ou transmissão de demandas, a nós trazidas por pacientes-detentos(as), era apontado como fora do escopo do que se espera de um trabalho religioso. Do próprio diretor, bem como de grande parte do corpo funcional com quem tínhamos contato, havia o argumento que nos contrastava negativamente com outros grupos religiosos frequentadores da instituição, notadamente as "Casas André Luiz" e algumas Igrejas evangélicas, com destaque para a Universal do Reino de Deus, cujas atividades eram pautadas pela realização de cultos e cânticos

${ }^{24}$ Deter-me-ei na questão das alas psiquiátricas em presídios no capítulo 2. Por ora, apenas cabe situá-las como uma estratégia de alocação de pessoas em medida de segurança que aguardam vaga para HCTPs. Como mencionado anteriormente, por não operarem em regime de superlotação, o excedente populacional destinado à custódia nos manicômios judiciários é alocado temporariamente em alas específicas de determinadas unidades penitenciárias paulistas, chamadas de "alas psiquiátricas", sendo paulatinamente transferido aos HCTPs mediante disponibilidade de vaga, nos moldes de uma fila de espera.

${ }^{25}$ Não demarco o gênero feminino pois, por ter sido uma rebelião arquitetada por custodiados do pavilhão masculino, esse evento, em específico, não produziu interferência no fluxo de chegada e saída de pacientes-detentas. 
religiosos junto aos(às) pacientes-detentos(as), ou doação de alimentos, vestuários e itens de asseio. Em certa visita, quando por mim interpelado quem eram dois senhores que carregavam uma grande sacola, o agente de disciplina de um dos setores respondeu-me: "Eles são das Casas André Luiz e vêm fazer assistencialismo...trazem algumas coisas para os pacientes". Por conta disso, percebíamos que, diferentemente de outras ordens religiosas, nosso acesso a determinadas instalações ou mesmo desautorizações de entrada, como foi dito com o episódio referente ao ofício, eram mais restritivas e arbitrárias comparativamente à flexibilidade de que gozavam os demais grupos religiosos.

No que concerne a como a "parte social" era mobilizada pelo GT, as tensões giravam em torno do fato de que "a parte religiosa" era dirimida, conforme alegavam alguns membros, frente "à social", ao mesmo tempo que, de outro lado, a primeira era entendida como demasiadamente litúrgica e pouco prática por outros. Esse embate provocou um crescente irreconciliável de tensões que culminou na fratura do grupo. $\mathrm{O}$ principal motivo do descontentamento devia-se ao fato de que, enquanto a leitura de uma passagem bíblica era lida em voz alta junto aos(às) pacientes-detentos(as), outros(as) membros(as) circulavam por entre pacientes-detentos(as) que não estivessem participando da "roda de oração", como era chamada, para recolher, caso quisessem, demandas que precisassem de encaminhamento. Se, por um lado, a concomitância dessas atividades fazia com que ganhássemos tempo para a "parte social", ela tanto desgastava as relações internas quanto deixava evidente para o corpo funcional que nos observava uma clara separação no grupo, a qual, posteriormente, resultaria oficialmente na divisão do GT.

Entretanto, não somente no âmbito interno ao GT essa tensão entre o que seria "mais religioso" ou "mais social" era delicada, mas era um ponto de fratura que atravessava outras instâncias da PCr. Um evento ilustrativo de suas dissidências institucionais em torno de distintos repertórios religiosos e que marca sua história como uma das crises internais mais agudas, como me falou um agente pastoral que há muitos anos assume um cargo na coordenação arquidiocesana, é a situação decorrente de uma rebelião prisional que ocorreria meses após essa visita, no interior do Estado de São Paulo.

Em abril de 2018, irrompe uma rebelião de presos na penitenciária masculina de Lucélia, localizada no extremo oeste paulista. Logo que a notícia chegou ao conhecimento dos Escritórios Nacional e Estadual da PCr, houve uma imediata mobilização para que alguns membros, em âmbito da Arquidiocese de São Paulo, juntamente com outros da 
diocese local, se fizessem presentes junto aos familiares de presos que lá estivessem, ansiosos por notícias dos seus. A situação era também delicada pelo fato de defensores públicos vinculados ao NESC terem sido feitos reféns.

As repercussões da rebelião se fizeram sentir em múltiplas esferas, muito para além do tempo de sua duração. Rebeliões como essa, e isso aprendi enquanto agente pastoral, engatilham um leque de preocupações relacionadas ao manejo político por parte da SAP. Ao mesmo tempo que eventos como esse demandam posicionamentos da $\mathrm{PCr}$, eles são instrumentalizados pela SAP como carta branca para uma miríade de arbitrariedades institucionais tanto às pessoas que estão presas quanto a seus familiares, reverberando também nas dinâmicas do trabalho de visitas pastorais. Tais arbitrariedades vão desde a aplicação de uso desproporcional da força, incluindo práticas de tortura e maus tratos, até a omissão de informação a pais, cônjuges e filhos(as).

Como era esperado, sob o pretexto de segurança, as visitas de familiares e agentes religiosos foram suspensas a nível estadual por tempo indeterminado, isto é, em todas as unidades prisionais do Estado de São Paulo, seguindo ordem do secretário de administração penitenciária à época. $\mathrm{O}$ entendimento de que o sistema carcerário é integrado, sobretudo pela abrangência do Primeiro Comando da Capital (PCC) no comando da maioria das penitenciárias paulistas ${ }^{26}$, faz com que o receio de um efeito dominó por todo o estado coloque em xeque uma leitura pontual e contingencial de um evento como esse. É notório, nesse sentido, os "ataques do PCC" ocorridos em 2006 e que se iniciaram com uma rebelião na penitenciária paulista de Avaré (Marques, 2009:9). Assim, a rebelião de Lucélia repercutiu espacial e temporalmente, justificando que a proibição das visitas familiares e pastorais fosse outorgada.

A 8 de julho de 2018, o Escritório Nacional da PCr lança uma nota de repúdio às repercussões restritivas e violadoras por parte da SAP, ressaltando o efeito cortina de fumaça ocasionado pelo argumento da "segurança" 27 . Como vemos no excerto de seu texto, existe a tentativa de aliar o trabalho religioso a um repertório normativo-legal doméstico e internacional que assegura a política de visitas como um imprescindível mecanismo de defesa dos direitos humanos:

Além da assistência religiosa, também faz parte do trabalho da PCr verificar se os direitos humanos dos presos não estão

\footnotetext{
${ }^{26}$ Há relevantes bibliografias que aprofundam a ingerência do PCC nas unidades penitenciárias paulistas com propriedade. Destaco aqui os trabalhos de Marques (2009, 2017), Biondi (2009, 2018) e Feltran (2018).

27 Para acessar nota na íntegra, ver: https://carceraria.org.br/igreja-em-saida/nota-da-pastoralcarceraria-nacional-sobre-as-restricoes-ao-atendimento-religioso-em-sao-paulo
} 
sendo violados. Essas restrições podem ocultar possíveis violações de direitos humanos e torturas, tão comuns no cárcere.

O relatório Assistência Religiosa no Cárcere: relatório sobre restrições ao trabalho da Pastoral Carcerária, lançado pela $\mathrm{PCr}$ em fevereiro deste ano que mapeou casos de restrições ao trabalho dos e das agentes da Pastoral pelo Brasil, é categórico em afirmar que a assistência religiosa é um direito que deve ser garantido.

"A assistência religiosa à pessoa presa é um direito constitucionalmente garantido e se vincula à própria inviolabilidade de culto e crença, também prevista na Constituição Federal e na Declaração Universal dos Direitos Humanos. Além disso, as 'Regras Mínimas para Tratamento de Pessoas Presas', da Organização das Nações Unidas (ONU), a Lei de Execução Penal (LEP) e a Resolução 8/2011 do Conselho Nacional de Política Criminal e Penitenciária (CNPCP) garantem o atendimento religioso às pessoas privadas de liberdade, não comportando qualquer tipo de cerceamento ou restrição. No entanto, mesmo com essas garantias legais, a assistência religiosa ainda é, muitas vezes, dificultada ou mesmo impedida" (Nota do Escritório Nacional,2018, online).

No dia seguinte ao lançamento da nota de repúdio do Escritório Nacional, no entanto, é lançada uma contra nota do Escritório Estadual da PCr, repudiando essa manifestação com o argumento de que tal posicionamento seria "extremo" e contraditório aos objetivos a que a PCr se propõe. Com a seguinte epígrafe, que é também o último período do texto, a nota inicia:

Acreditamos firmemente que o diálogo com todas as pessoas e instituições sempre é e será o melhor caminho para a resolução dos problemas. A Evangelização nos Cárceres é um grande desafio, e a Pastoral Carcerária, como realidade da Igreja, em todas as suas instâncias, deve evitar atitudes extremas. (Nota do Escritório Estadual, 2018, online) ${ }^{28}$

A principal reivindicação do Escritório Estadual residia no fato de que uma postura institucional adequada a uma situação extrema como essa seria algo distante do enfrentamento e mais próximo ao diálogo, como expresso na menção, no mesmo texto, a uma audiência com o secretário da SAP, na qual estiveram presentes "o Bispo Referencial da PCr-SP, [nome do bispo], e integrantes da Coordenação [Estadual]” . Com as seguintes palavras, grafadas em negrito, a nota cita o "caráter temporário das restrições", nas palavras do próprio secretário.

Além da referida audiência, o "caminho do diálogo" seria exemplificado pela ocorrência da Assembleia Estadual da PCr apenas dias depois do estouro da rebelião, na

${ }^{28}$ Para acessar nota na íntegra, ver: http://www.cnbbsul1.org.br/pastoral-carceraria-estadualemite-nota-de-resposta-a-pcr-nacional-com-relacao-as-restricoes-ao-atendimento-religioso-em-sao-paulo/ 
qual, reunindo diversas dioceses paulistas, se discutiu coletivamente a pauta das restrições. Nessa reunião, ainda segundo o texto da nota, colocou-se em evidência que, apesar das restrições limitando os agentes pastorais às grades, sem que adentrassem aos pátios e, consequentemente, pudessem ter contato direto com as pessoas presas, o trabalho religioso seguia sem maiores conturbações. À afirmação de que "O Bispo Referencial e a Coordenação Estadual da PCr-SP têm mantido contato contínuo com o Secretário" acrescenta-se que o diálogo dos agentes pastorais incluiria, “os(as) diretores(as) nas unidades prisionais".

O texto finaliza classificando a atitude como "totalmente isolada" por parte do Escritório Nacional, fato que não coaduna com "a comunhão e unidade eclesial", fazendo-lhe um convite para o respeito às "instâncias existentes criadas pela Igreja (...), para anunciar o Reino de Deus e visitarmos a Jesus Cristo presente nas pessoas privadas de liberdade".

É interessante notar que ambas as notas empregam a palavra "tensionar", porém com significados totalmente distintos. Na nota estadual justifica-se a recusa de assinatura do Escritório Estadual como uma atitude que "poderia tensionar e piorar ainda os trabalhos da Pastoral Carcerária nas Unidades Prisionais do Estado de São Paulo"(ênfase minha) ao passo que, na nota nacional, a restrição de visitas a familiares e agentes pastorais “só serve para tensionar ainda mais o sistema prisional”(ênfase minha).

\section{Mateus 13, 10-17}

Uma vez terminada a conversa na sala da diretoria, saímos intrigados com a súbita valorização da "parte social" por parte do diretor e nos dirigimos à primeira ala a ser visitada: a ala feminina. Pegamos novamente o carro seguindo pela continuação do estreito caminho de paralelepípedos, margeando as ruínas ainda visíveis em meio a já novas edificações do pavilhão destruído pela rebelião, até que ele se transformasse em estrada de terra em meio à densa vegetação. No que seria uma espécie de clareira, localiza-se outra edificação térrea, porém sem cercamentos metálicos, com janelas gradeadas e alguns cachorros circulando na área logo à frente da entrada.

Atravessando a porta de metal opaca onde se lê, em adesivo fixado: “Seja feliz: não se irrite, critique, grite, acuse. Sorria, auxilie, converse, ampare”, somos conduzidos a uma antessala onde depositamos nossos objetos no aparelho de raio $\mathrm{X}$ e passamos nosso corpo pelo detector de metais, tantas vezes quanto necessário até que o batente acinzentado 
através do qual somos obrigados a passar não nos acuse objetos como chaves, colares metálicos ou fivelas. No estreito corredor que conecta a antessala ao pátio interno, temos as salas de enfermagem, onde são preparados os medicamentos, e a enfermaria, composta de uma maca com cintos de contenção para casos de administração intravenosa de fármacos. Ao fundo, está a porta de metal gradeada que dá acesso à área onde as pacientedetentas circulam nos horários livres. Trata-se de um relativamente amplo perímetro retangular com duas mesas com alguns assentos, quase encostados em paredes de onde irrompem as grandes janelas gradeadas, vistas do lado de fora. Nessa mesma parede, há outra porta que dá acesso ao pátio externo.

Nossas conversas sempre se dão nesses dois espaços coletivos, uma vez que o acesso aos quartos é restrito à equipe pastoral pela diretoria da unidade ${ }^{29}$. Ali, as pacientedetentas conversam em grupos, marcham em círculos para se exercitar, ou mesmo passam o tempo sozinhas. Não há nada em comum entre elas a não ser o característico uniforme bege-marrom com os dizeres "HCTP I" em estampa de cor preta, o mesmo utilizado pelos homens.

Enquanto adentrávamos, saudamos funcionários(as) e pacientes-detentas que cruzavam nosso caminho, seguindo para o pátio aberto. Lá, o padre que nos acompanhava anunciou que faria uma "leitura da Palavra", convidando, a quem quisesse, juntar-se a nós. Fizemos, então, a tradicional "roda de oração" com todos(as) os(as) membros do GT presentes, evitando a separação de dois momentos que existia anteriormente à cisão.

A leitura por ele escolhida para o dia foi Mateus 13, 10-17:

Então os discípulos chegaram perto de Jesus e perguntaram: - Por que é que o senhor usa parábolas para falar com essas pessoas? Jesus respondeu: — A vocês Deus mostra os segredos do Reino do Céu, mas, a elas, não. Pois quem tem receberá mais, para que tenha mais ainda. Mas quem não tem, até o pouco que tem lhe será tirado. É por isso que eu uso parábolas para falar com essas pessoas. Porque elas olham e não enxergam; escutam e não ouvem, nem entendem. E assim acontece com essas pessoas o que disse o profeta Isaías: "Vocês ouvirão, mas não entenderão; olharão, mas não enxergarão nada. Pois a mente deste povo está fechada: Eles taparam os ouvidos e fecharam os olhos. Se eles não tivessem feito isso, os seus olhos poderiam ver, e os seus ouvidos poderiam ouvir; a sua mente poderia entender, e eles voltariam para mim, e eu os curaria! - disse Deus." Jesus continuou,

${ }^{29}$ Vale ressaltar a arbitrariedade dessa restrição uma vez que, enquanto agentes pastorais, além de nossas visitas serem constitucionalmente garantidas, segundo portarias da própria SAP, temos direito a entrar em todos os espaços das unidades prisionais. 
dizendo: - Mas vocês, como são felizes! Pois os seus olhos veem, e os seus ouvidos ouvem. Eu afirmo a vocês que isto é verdade: muitos profetas e muitas outras pessoas do povo de Deus gostariam de ver o que vocês estão vendo, mas não puderam; e gostariam de ouvir o que vocês estão ouvindo, mas não ouviram.

Na sequência, fez uma breve interpretação do texto dizendo que quem tem ouvidos deve ouvir, porque "receber a Palavra é como receber um remédio: cada um tem o seu". Assim como "o remédio cura de doenças", ressaltou, a "Palavra pode curar vícios e sentimentos negativos". Encerrou, então, com um "Pai Nosso" e uma "Ave Maria", dispondo-se a conversar em particular a quem desejasse lhe falar. A roda se desfez e nós nos dividimos a fim de fazer-nos disponíveis para conversa no tempo que nos restava antes que o almoço fosse anunciado.

\section{"Caio, vem cá que quero conversar com você. Anota tudo no caderninho"}

Até Daiana tornar-se visível para mim, levou algum tempo. Tomei conhecimento de sua existência no HCTP devido, principalmente, a comentários da diretoria e do corpo funcional, sempre pautados por sua intempestividade. "Ela está dando trabalho novamente" ou "Ah, A Daiana...", eram proferidos com um certo torcer da boca e um virar de olhos como a dizer sobre a particularidade de seu caso ${ }^{30}$. Daiana era alguém presente para mim somente por relatos de seu comportamento ou por breves momentos em que pude vê-la na ala feminina, ora conversando com outras pacientes-detentas, ora com as demais agentes de PCr que compõem a equipe. Tinha notado, mesmo sem nunca ter trocado qualquer palavra com ela, que tinha uma preferência por conversar com as mulheres do grupo, o que me fez nunca ter uma iniciativa de me aproximar, esperando que viesse falar comigo. Percebi também que, às vezes, colocava-se a certa distância, observando o que se passava enquanto eu conversava com outras que me traziam suas demandas: “o senhor poderia dar uma ligadinha para minha família?”, ao que respondiam, diante de minha afirmativa, com um: "muito obrigada! Deus te abençoe".

As demandas sempre foram muito variadas nesses dois anos de visita, mas certamente a busca pelo contato familiar figura no topo como a mais requisitada. Ainda

\footnotetext{
${ }^{30}$ O caso de Daiana aproxima-se substancialmente do caso de Patrícia, uma detenta da Penitenciária Feminina da Capital cujo prontuário foi minuciosamente investigado por Padovani (2010) e sobre quem laudos e falas, assim como vemos com Daiana, construíram "uma personagem monstruosa", uma espécie de mito sobre o qual a instituição penal legitima sua própria existência (Padovani, 2010:155).
} 
assim, a primeira vez que, finalmente, pude conversar com Daiana não foi uma demanda de contato familiar que a aproximou de mim.

"não apresentava problemas importantes nos órgãos dos sentidos na fala e na deambulação (...). Como se sabe, a Esquizofrenia é uma grave doença mental que se caracteriza pela desorganização do psiquismo, especialmente do pensamento e da afetividade o que dá margem a causar, no indivíduo uma visão própria da realidade (...). Quanto aos autocuidados necessita melhorar, a memória está preservada, a atenção e concentração são comprometidas, possui dificuldade de expressão do que sente e do que pensa de maneira que ela acredita que deveria ser ideal, assim se corrigindo $e$ questionando se estava correta sua colocação. Necessidade de gratidão imediata, não tolera frustração. Tem a necessidade de chamar atenção e sentir-se amada". (trecho de laudo de cessação de periculosidade).

"Caio, vem cá que quero conversar com você. Anota tudo no caderninho". Foi com essa frase que estabelecemos nosso primeiro contato. Depois de observar tantos pedidos de outras pacientes-detentas transformados em garranchos apressados em meu caderninho de anotações, ela quis que as suas palavras também fossem ali grafadas num tom que mesclava autoridade com certa afetuosidade.

Assim, saímos da área conhecida como "convívio" - área quadrangular e coberta onde, em determinados momentos do dia, as pacientes-detentas são autorizadas a circular. Relativamente bem iluminado, com um pé direito de aproximadamente três metros, o ambiente é assentado sobre um chão de pedra tom musgo com duas mesas e pequenos bancos individuais fixos ao chão, localizados paralelamente a uma das paredes. Como ambiente central da arquitetura da ala feminina, é margeado ao lado esquerdo de quem entra por um pátio aberto, cujo acesso se dá por uma porta numa parede branca de onde se irrompem quatro janelas gradeadas, à frente para acesso às salas de aula e à direita por uma única porta que dá acesso aos quartos, também chamados de “celas", onde, nós, agentes pastorais, não somos permitidos adentrar. Chegando ao pátio descoberto, onde momentos antes fora feita a "leitura da Palavra", nos sentamos no pequeno desnível que delimita o espaço do que poderia ser descrito como uma espécie de coreto, também de formato retangular que preenche o centro do pátio.

Encostada em uma das vigas, o rosto de Daiana parcialmente iluminado pelo sol quente daquela manhã permitiu-me estacionar sua face em minha visão, uma vez que muitas não me ficam retidas devido ao contato fugaz, em que imediatamente após anotar uma demanda, percebo alguém atrás esperando sua vez para falar comigo. Por isso, nome e rosto nem sempre se associam em minha memória, obrigando-me, a cada nova visita, 
fazer a constrangedora pergunta diante de um lembrete ao que me foi pedido: "Desculpe, você é a...?". Segue-se, então, o folhear ansioso no meu caderninho que me leve ao seu nome completo com a matrícula o mais rápido possível. Carrego-o sempre comigo nas visitas, tomando um certo cuidado, sobretudo, ao que se refere a funcionários(as) dos HCTPs a fim de que a privacidade dos pedidos seja garantida, o que me faz orgulhar, somente nesses momentos de vigilância, de minha letra itálica garranchuda, ilegível senão por uma aproximação de quase tocar o nariz na folha. A ilegibilidade, nesse caso, faz-se importante como estratégia de garantir a confidencialidade do trabalho pastoral de assistência humanitária, evitando que o(a) paciente-detento(a) sofra retaliações caso seu conteúdo torne-se publicizado.

Ano de Nascimento: 1993; Pele: NEGRA; Tipo de Cabelos: CARAPINHOS; Cor de Cabelos: CASTANHO; Cor Olhos: PRETOS.

\section{SINAIS PARTICULARES}

Nascimento - local(is) do corpo: MANCHA ESCURA QUEIXO

Cicatrizes - local(is) do corpo: BRAÇO ESQ, PERNA D, JOELHO D, TESTA, PERNA ESQ (FACADA)

Tatuagens - local(is) do corpo: PERNA D(ESTRELA), BRAÇO ESQ(VERA) (Laudo de cessação de periculosidade)

“Caio, eu não aguento mais esse lugar”. A partir dessa fala, Daiana começou a chorar e, com a voz embargada, dizia que estava muito cansada, "exausta". Não aguentava mais. Enquanto olhava rapidamente para seu antebraço com inúmeras cicatrizes transversais, que formavam um espesso queloide em sua pele, Daiana mostrou-me, levantando a camiseta de seu uniforme, os pontilhados escurecidos em seu ventre decorrentes de queimaduras com isqueiro que, assim como os cortes, provocava a si mesma. Canetas bic, cacos dos bulbos de lâmpada, ou pequenas pedras serviam-lhe de instrumento cortante.

Enquanto observava suas marcas, ouvia me dizer que sua motivação residia na sensação de conforto que os cortes e queimaduras propiciavam. Segundo ela, as automutilações eram seu único modo de encontrar conforto emocional pois a deixavam "feliz", reiterando que não sentia dor física. Enquanto a ouvia, percebi que tanto o tamanho quanto a espessura da cicatriz em seu antebraço, bem como o número de queimaduras, comunicavam que aquilo já ocorria há muito tempo. 
"Na data XX/XX/2013, no interior desta Unidade Prisional, a reeducanda [nome completo de Daiana], Mat:XXX.XXX-X teria provocado autolesão como forma de rebeldia." (Despacho decisório $\mathrm{XXX} / \mathrm{XXXX}$ ).

"Comunico a Vossa Senhoria que na data e horário supracitados, as reeducandas da referida cela solicitaram atendimento da funcionária do setor devido a reeducanda em tela estar se cortando, ao chegar ao setor verificamos que a mesma havia cortado em diversos pontos o braço e o pescoço com uma gilete, porém segundo a funcionária do setor sem necessidade de ponto, a mesma foi medicada e feito os curativos necessário alojada na cela $X$ da enfermaria (sic). Diante do exposto levo a conhecimento para que sejam tomadas as providências cabiveis." (Comunicado de evento XXX/XXXX).

"Às 17h30 novamente paciente [Daiana] ateou fogo no próprio corpo, contida pelos ASPs ${ }^{31}$, trazida para a enfermaria, medicada novamente. Obs: O Aparelho de dentro está com problema. Os demais aparelho permanente, estão em ordem (sic). Passo plantão com as duas pacientes [Daiana] $e$ [nome de outra paciente-detenta] na sala de observação. Temos 79 pacientes e prontuários" (fotocópia de ata de plantão, feita em papel de caderno, redação à mão)

Com efeito, tempos depois, confirmaria minha hipótese de longevidade de suas práticas com seu corpo pelo estudo detido dos calhamaços que compunham seu processo de execução penal e seu processo disciplinar ${ }^{32}$, o qual constitui um tomo à parte. A cada automutilação de Daiana, abre-se um novo processo disciplinar que, em geral, segue um mesmo padrão: abre-se com um relato da ocorrência e encerra-se com um atestado médico de sua disfunção mental.

"Só assim eu me sinto bem nesse lugar". A conversa continuava com a reiteração de sua exaustão e não sabia muito o que dizer diante do seu desabafo, limitando-me a apenas olhar em seus olhos marejados e escutar suas palavras. Não havia exatamente demandas práticas de ligação ou contato com o setor de serviço social que eu devesse fazer e, embora ela tivesse pedido para que eu anotasse "tudo", não sabia o que fazer com meu caderninho naquele momento; ali, ele parecia completamente dispensável.

Uma fila de mulheres já se formava logo atrás de nós, diante da porta do refeitório. Era hora de sairmos dali.

\footnotetext{
${ }^{31}$ Sigla para Agente de Segurança Penitenciário.

${ }^{32} \mathrm{O}$ processo de execução é o conjunto de documentos jurídicos que atestam o andamento da pena
} ou, como é o caso aqui, da medida de segurança (apelação, progressão de regimes, concessão de indulto, entre outros). O processo disciplinar, por sua vez, consiste no registro de faltas disciplinares cometidas durante a execução. Interessante notar que as automutilações de Daiana são enquadradas nessa categoria, em termos de uma má conduta. 


\section{Quando ver é não enxergar e escutar é não ouvir}

“esse olhar da PCr que tenta escutar, visitar, estar presente" é uma tentativa de "colocar o debate sobre o fim do sistema prisional". A frase que foi usada para descrever a contribuição do Relatório Hospitais-Prisão destaca a "presença" em serviço da escuta, a nível cotidiano, que se fez fundamental para seu processo de redação. Ou seja, o texto que deu origem ao relatório e escrito coletivamente pelo GT bebeu, majoritariamente, do visto e ouvido das "narrativas" de nossos interlocutores nos HCTPs, fontes principais de seu conteúdo.

Entretanto, colocando em perspectiva uma das visitas realizadas pelo GT, procurei questionar o que é mobilizado por uma certa "economia de enunciados" (economy of statements, Hartman, 2008:13), na qual "a Palavra" e as palavras de agentes pastorais e de "excluídos" são o combustível da operacionalização do "ver" através da "escuta" na persecução de um "mundo sem cárceres".. Um primeiro ponto a destacar é que os sentidos de visão e audição evocados, menos que uma referência às capacidades fisiológicas humanas, traz à tona um olhar e ouvir dependentes de uma moralidade, base mesma da noção de "testemunho", para operarem. Isso significa que o "olhar que escuta" só acontece mediante um deslocamento de "caminhar em direção às periferias do mundo”, tal como convida Papa Francisco (Cartilha PCr, 2015:5), a fim de estar junto aos que "sofrem e padecem", como dito no lançamento do relatório.

Contudo, o imbricamento entre teoria e ação/política e religião que o "olhar que escuta" sugere não ocorre como atitude passiva. Devido à moralidade que lhe dá sustento, deve-se entendê-lo na chave não do que é, mas do que deve ser visto e ouvido, em conformidade ao "ver", "julgar" e "agir". As situações aqui narradas procuram colocar em relevo justamente o dissenso causado pela sua polissemia, mobilizando posturas institucionais, às vezes, antagônicas. Os mútuos deslocamentos, a depender do ângulo moral-institucional adotado, entre "parte social" e "parte religiosa", fortemente confrontados nas situações narradas, ilustram as disputas acionadas entre os diferentes atores.

Assim, menos do que um antagonismo entre PCr e HCTPs na busca de "um mundo sem cárceres", o que parece evidente é a emergência de "emaranhados institucionais" formados por "fragmentos de organizações" - Escritórios Nacional e Estadual, GT, SAP, HCTP e assim por diante - operantes dinamicamente por aproximação ou distanciamento a depender do que se defendia como escuta e visão (Morawska, 2010). Nessas disputas, 
documentos de várias ordens são mobilizados, funcionando como disparadores ou legitimadores das relações político-morais estabelecidas. Ao não os reduzir a meras ferramentas de registro, alinho-me aqui à perspectiva de Ann Laura Stoler (2010), quando de seu estudo a respeito dos arquivos coloniais holandeses. Seu enfoque analítico do que os documentos significam me é particularmente interessante, uma vez que se desloca de um enfoque analítico restrito ao seu conteúdo, atentando para aquilo que o excede; para o que reverbera em suas margens.

Nesse sentido, a autora propõe um giro metodológico a fim de entender arquivos documentais menos como "objetos" (archiving-as-things) do que "processos" (archivingas-process) (Stoler, 2010:20). Ao convidar-nos a "percorrer o veio dos arquivos", a autora faz um alerta de que, longe de percorrer um "curso sem fricções" (frictionless course), estamos entrando num "campo de força" (field of force) e de "exercício de poder"(will to power) (ibid:53). ). Documentos, portanto, são atores ativos. Eles afastam e aproximam instâncias, configuram posicionamentos políticos de equipes pastorais e reverberam na recepção dessas equipes pelas diretorias prisionais. No meu caso, por exemplo, o conhecimento da nota nacional por parte das diretorias dos HCTPs de Franco da Rocha impactou nas visitas subsequentes à sua divulgação devido à menção explícita, na redação, de que os hospitais de custódia operavam restrições de entrada ao GT, no contexto das arbitrariedades discutidas.

Além disso, vemos como ambas situam a importância do "testemunho" para a manutenção do trabalho pastoral, porém desde posicionamentos distintos, refletindo também o par opositivo "religioso" e social". A nota do Escritório Nacional critica o impedimento das visitas como uma censura da SAP a fim de obstaculizar uma importante função do "testemunho" no cárcere, a saber, a identificação de violações de direitos humanos, que, sem abster de uma linguagem teológica, aproxima a centralidade da visita a normativas-legais estatais, garantidoras do que seria um "direito" da pessoa presa. De outro lado, a contra nota Estadual classifica a própria nota como uma atitude "extrema", cuja publicização do impedimento das visitas poderia ser uma ameaça à continuidade desse trabalho de "Evangelização nos cárceres", legitimando-o desde um ponto de vista marcadamente teológico, que seguia a despeito das restrições impingidas à entrada da PCr. Se, na primeira, a "escuta" está mais direcionada à população encarcerada, “com quem formam-se vínculos verdadeiros de solidariedade", na segunda vemos sua ênfase 
no "diálogo" com as instâncias estatais. Mais do que manifestações de repúdio por meio da escrita, temos, na verdade, inconciliáveis maneiras de "ver" uma "realidade".

O acoplamento entre moral e os deveres de "ver" e "escutar" é também o ponto central da leitura da "Palavra" daquela visita. Como representantes da PCr na categoria de agentes pastorais, nossa participação na "roda de oração" com a leitura da passagem bíblica convidava as pacientes-detentas a serem como os discípulos, que são "felizes" porque seus "olhos veem e seus ouvidos ouvem”, condição que permitiria a cura de Deus. Os demais, ao contrário, necessitam de parábolas uma vez que "olham e não enxergam; escutam e não ouvem, nem entendem".

Assim, "se dar a Palavra é como dar o remédio", como terminou sua fala, a função do testemunho por nós ali performada seria análoga a de um médico com seus pacientes: ouve e anota atentamente seus sintomas a fim de que possa prover, individualmente, a cura; cada qual com seu remédio. "Escutar", portanto, parece implicar na reflexividade terapêutica de "dar a Palavra" como forma de "agir" na "realidade". Isso parece ter ressonância na expectativa do diretor, quando da inesperada valorização de nossas visitas ao HCTP, assumindo que nosso trabalho seria importante para aplacar, quase que profilaticamente, os ânimos dos “estressados” reingressantes vindos da PIII.

A moralidade aqui subjacente ressoa também com a ideia de "poder pastoral" de Foucault (2008). Para o autor, a particularidade dessa relação de poder, mobilizado pelo imperativo de defesa da vida e muito próximo ao que define como "biopoder", seria seu exercício não pela superioridade ou força, qual o faz o poder soberano, mas como uma tecnologia produtora de subjetividades em que o cuidado ganha papel central. Ao mesmo tempo que tem um caráter coletivo a fim de gerir a população, ele é produtor de individualidades, porquanto o pastor tanto sabe conduzir seu rebanho quanto conhece cada uma de suas ovelhas. Cito:

\section{O poder pastoral é um poder de cuidado. Ele cuida do rebanho, cuida dos indivíduos do rebanho, zela para que as ovelhas não sofram, vai buscar as que se desgarram, cuida das que estão feridas. O pastor zela por seu rebanho, está a serviço dele, é seu intermediário (Foucault, 2008:170).}

À luz de sua reflexão, seria razoável depreender que a prática de "escutar" da PCr é inseparável de uma prática de poder, na qual a importância da "palavra", tanto em seu sentido sagrado quanto profano, não tem valor em si, senão em sua capacidade de circulação. É um poder que se exerce em movimento, análogo à condução do rebanho pelo pastor e contrário ao imobilismo do trono do poder soberano. Fica patente, nesse sentido, a imprescindibilidade das visitas ressaltada pelas notas dos Escritórios Nacional 
e Estadual e reivindicada na tentativa de entrada quando da interdição de acesso ao GT sob a alegação de que o ofício não fora enviado: a ameaça ou obstáculo ao acesso a unidades prisionais não deixa de ser uma ameaça na capacidade do fornecimento, a partir do trânsito, do "verbo que se fez carne" em direção "às periferias do mundo" e, por conseguinte, uma ameaça à realização plena do "testemunho"; da prerrogativa da proteção.

É paradigmático, como aponta Foucault (2008), a figura metafórica de Moisés no que se refere ao seu atributo de conduzir os hebreus à salvação, atributo esse que, de acordo com a bíblia, somente lhe foi divinamente conferido quando se tornou pastor. Com relação ao "testemunho" da PCr, a analogia com Moisés é sugerida logo na primeira seção da Cartilha PCr, intitulada "ver", em que temos como epígrafe um excerto do Êxodo. Ela sintetiza os propósitos pastorais, fazendo do "ver" e "ouvir" do "sofrimento" de "oprimidos" o motivador da "descida", sugestiva do indispensável movimento, para a "libertação":

Eu vi muito bem a miséria do meu povo (...) Ouvi o seu clamor contra seus opressores, e conheço os seus sofrimentos. Por isso, desci para libertá-lo (...) (Ex 3,7-8, ênfases minhas).

"Caio, vem cá que quero conversar com você. Anota tudo no caderninho". Como contou-me em nossa conversa, para Daiana, eram os cortes que se infligia a única maneira se sentir "feliz". Sua fala me provocou a pensar, diante da passagem bíblica lida apenas momentos antes, quando "dar a Palavra" não produz a profilaxia prometida nos seus versos: “Jesus continuou, dizendo: - Mas vocês, como são felizes! Pois os seus olhos veem, e os seus ouvidos ouvem." (Mateus 13, 10-17).

Porém, mesmo quando a palavra é profana, como no momento "mais social" quando pudemos ter uma conversa particular, simplesmente não havia o que pudesse dizer ou anotar, o que me fazia interrogar a serviço de que ou quem estava aquele momento de "escuta". Tantas palavras e tantos "remédios" administrados pelo HCTP a fim de chegarse a qual cura? Os laudos de Daiana falam de medicamentos que lhe eram dados logo após suas recorrentes autolesões. Creio, então, que a repetição dessas ocorrências coloca o questionamento tanto dos propósitos dessa profilaxia medicamentosa, a qual determina categoricamente que, "quanto aos autocuidados precisa melhorar", quanto da palavra que, supostamente, proporciona "felicidade".

Naquele contexto, tentar escutá-la parecia dar-me a impressão de que fazia algo não muito diferente ao que as paredes do HCTP falavam. Como ensinava o cartaz da 
antessala da diretoria, o "olhar amigo" é justamente o da prontidão para o cuidado, ágil e sensível o suficiente "antes que seja tarde". O adesivo na porta de entrada da ala feminina, por sua vez, instruía com poucas palavras como ser "feliz: não se irrite, grite, acuse. Sorria, auxilie, converse, ampare”. E, à medida que o tempo passava em nossa conversa, sentia-me mais próximo "àquelas pessoas" do que aos discípulos, com as quais as primeiras, nas palavras de Jesus, contrastam: "Vocês ouvirão, mas não entenderão; olharão, mas não enxergarão nada. Pois a mente deste povo está fechada (...)". O que deveria ser aberto para que pudesse entender e enxergar Daiana?

Como dito, uma das minhas tentativas a fim de entender melhor sua situação foi “abrir" seu processo penal, o qual inclui também seu processo disciplinar. O último capítulo desta dissertação procura detalhar como se dá o trabalho de consulta aos autos judiciais, mas, por ora, o importante a ser sublinhado é como o trabalho de "escuta" comumente dependia de uma complementação, isto é, de ouvir não só nossos interlocutores, mas os muitos papeis a seu respeito.

No caso de Daiana, enquanto tentava escutá-la, via que suas cicatrizes comunicavam que sua prática com seu próprio corpo não era recente. $\mathrm{O}$ desconhecimento de quem ela era, a não ser pelos comentários do corpo funcional, bem como o de sua cicatriz, fizeram-me pensar que poderia tentar entender melhor sua história se fizesse um levantamento de seu processo penal. Isso implicava buscar, em outro espaço físico, uma específica fonte de informação sobre Daiana, conectando-a diretamente com a $5^{\circ}$ Vara de Execuções Criminais (VEC), onde se encontram seus papeis, bem como os de toda a população em medida de segurança no Estado de São Paulo. Ouvir uma história, seja pelas palavras ou pelo corpo de outrem, impelia, portanto, incursões que transcendiam o âmbito do HCTP, seguindo as "ressonâncias" de seu enredo para outros lugares e tempos.

Assim, o testemunho que, como vimos, é inexoravelmente uma prática de movimento e circulação, tem como condicionante determinados trânsitos a serem feitos nos quais, levar ou escutar a palavra, é uma mediação essencial. No caso do Relatório Hospitais-Prisão, como expresso no seu evento de lançamento, é clara a intenção de "transmitir a palavra" de custodiados(as) fazendo "ressonâncias" com outros relatórios e instituições estatais. Da mesma forma, o trabalho pastoral de visitas aos HCTPs teve como base a tentativa de dar encaminhamento ou resolução às demandas que nos eram trazidas, o que fazia do registro um instrumento imprescindível para que elas não se perdessem em meio ao grande volume que nos chegavam. Demandas de ligações familiares, por 
exemplo, ressoavam para outras cidades ou estados, buscando consolidar as conexões que nos eram pedidas. Em outro plano, a despeito do laborioso trabalho de escrita e edição, nossos caderninhos não deixam de "ressoar" nas páginas do Relatório Hospitais-Prisão, cujo conteúdo é fortemente assentado no que foi visto e ouvido a partir da experiência de visitas, daquilo que foi registrado em nossos instrumentos de anotação das "narrativas silenciadas pelos muros prisionais".

Nossos caderninhos, portanto, também transitavam por diferentes espaços, ao mesmo tempo que pareciam ser ativos construtores nas relações com nossos interlocutores. No caso de Daiana, o fato de ter me visto com meu caderninho para conversar com outras pacientes-detentas parece ter sido um motivador para que, finalmente, viesse falar comigo; ela também queria ter "tudo" anotado. Embora não tivesse conseguido anotar absolutamente nada enquanto conversávamos, a despeito de seu enfático pedido, ela, com todos os pontos cegos e dúvidas sobre sua história, se inscreveu em minha memória e foi nesse mesmo caderninho que, posteriormente, registrei como transcorrera nossa conversa, acrescido de um lembrete em letras garrafais:

\section{“LEVANTAR PROCESSO”.}

O estabelecimento de relações mediadas por diferentes tipos de papeis suscita, no âmbito do testemunho, as imbricações entre corpo e escrita. Se, tal como escrito na apresentação do Relatório Hospitais-Prisão, Jesus pode ser referenciado como "Encarnação do Verbo", não me furto de pensar em que medida o trabalho de "pastoral da escuta" "encarna" a presença, mesmo quando o corpo não está fisicamente presente, mas impresso na memória ou em nossas páginas. Assim, não são os corpos que carregam histórias, mas as histórias que atravessam os corpos e se fazem "ver" através deles. A centralidade do corpo é também destacada na Cartilha PCr quando nessa se esclarece que, nas visitas, "não visamos somente a assistência espiritual, mas toda ajuda a elas e seus familiares, pois como nós elas também têm um corpo (cf. Hb 13,3 apud Cartilha PCr, 2014:17, grifo original).

Em sua experiência etnográfica com mulheres não-brasileiras encarceradas, Bruna Bumachar (2016) chama atenção para o que chama de "camada de interfaces" produzida pelas relações epistolares entre essas mulheres e seus destinatários, e que lança luz às reflexões tecidas sobre corpos e papeis no trabalho de testemunho da PCr. Quando descreve a relação epistolar de uma de suas interlocutoras, Bumachar atenta para como a leitura de uma carta "atualiza" a presença do remetente ao destinatário a partir do 
mobilização de "atos" e "sensações", disparados ao ler, que não mimetizam a presença, mas fazem da leitura pelo destinatário um momento de efetivo encontro, minando a lacuna espaço-temporal que as separa e colocando em xeque os limites que traçam os mundos intra e extramuros prisionais. Cito:

\begin{abstract}
Maretha nos sugere a produção de uma presença que se faz plena. Não há, em suas palavras, qualquer interrupção desse processo que justificaria o termo "quase". Ao contrário, há atos e sensações que as colocam, de modo inusitado, frente a frente. Atos e sensações que podem variar segundo o grau das presenças produzidas com diferentes técnicas e arranjos entre as "coisas" mobilizadas por remetentes e destinatários (Bumachar, 2016:216).
\end{abstract}

Apoio-me também na análise sobre as cartas trocadas entre mulheres presas e seus cônjuges em penitenciárias femininas de São Paulo e Barcelona feita por Natália Padovani (2018). Sua ideia de carta como "materialização da porosidade institucional” é valiosa para avançar o entendimento de papeis para além de seu conteúdo, ajustando o foco para não tanto o que as escritas dizem em si mesmas, mas para o que elas "tramam", isto é, suas "redes de afeto" e interconecções institucionais que produzem (Padovani, 2018:119). Ao circularem, elas conectam não só rementes e destinatários, mas sofrem revista pelos agentes penitenciários a fim de que a legitimidade das relações entre diferentes corpos, que se comunicam através da escrita, seja não meramente lida, mas gerida.

A antropóloga faz um interessante paralelo entre seu objeto de análise e os poemas escritos por prisioneiros de Guantánamo sobre os quais reflete Judith Butler, em Marcos de Guerra. Assim como as cartas trocadas entre as mulheres, os poemas escritos por prisioneiros do complexo penitenciário estadunidense são alvo de censura sob a alegação de que seu conteúdo oferece risco à segurança. Perscrutando o caráter ameaçador de tais obras escritas em papel, a filósofa estadunidense identifica um atributo "incendiário" das palavras, cujo efeito é produzir empatia e solidariedade em quem os lê, o que possibilita ao autor do poema ser "reconhecido como vida, ser personalizado".

Aportando-se na ameaça que os poemas representam para a opacidade de Guantánamo, na medida em que eles revelam sua "porosidade" pelas conexões estabelecidas, Padovani estabelece um paralelo com sua pesquisa ao entender que a censura das cartas recai menos numa "prática de segurança" do que controle das "redes de ajuda e solidariedade por meio das quais é possível subverter as relações de poder e criar estratégias de sobrevivência" (ibid, p.121). As cartas, portanto, segundo a autora, 
tanto "fazem ver a relação" quanto a personaliza, relação essa tanto entre corpos quanto instituições. Através do contato com uma interlocutora, a autora coloca em relevo como

Os papeis que me mostrava teciam relações entre prisões, mas também entre a rede de manutenção e produção das instituições penitenciárias: a casa de sua mãe, o fórum criminal, a Pastoral Carcerária, o pavilhão administrativo da unidade. (...) outra relação de Adelina, legibilizada pela tatuagem que ela carregava no seu antebraço (...) a enredaria ainda aos "trâmites" da Penitenciária Feminina de Santana, para onde Guinú - "sapatão" com quem Adelina começara a namorar durante sua estadia no terceiro pavilhão da PFC e de quem o nome ela havia tatuado no braço - havia sido transferido (Padovani, 2018:171).

“Caio, você sabe que é meu amigo, né? Não esquece de anotar no caderninho!" Continuei conversando com Daiana nas visitas subsequentes e pode-se dizer que uma relação de afeto acabou sendo forjada, apesar dos encontros quinzenais e, às vezes, mensais. Entretanto, não obstante a proximidade afetiva paulatinamente construída, ela jamais me contou a história de vida que esperava ouvir. Em lugar dela, o que ficava patente e se fazia ver através de nossa relação, é a história das "tramas" e "enleamentos" pessoais e institucionais produzida pelo imperativo da "escuta", ou, nas palavras do coordenador nacional, pelo "compromisso com os que sofrem e padecem". Em meios às tramas institucionais entre PCr e HCTP, sou, inescapavelmente, um dos vários entrecruzamentos. Ocorre, porém, que nem todos os pontos dessa "trama" me são acessíveis, o que também fala sobre os limites do "ver" e "escutar" reivindicados como basilares no trabalho pastoral.

Se, no caso de Adelina, sua tatuagem a enreda com sua amante, no caso de Daiana, os fios ou entrecruzamentos que ligavam a cicatriz de seu antebraço permaneceram invisíveis e inaudíveis a mim. A leitura de seus laudos, tampouco foi elucidativa nesse sentido, apontando, na verdade, para como os seus papeis estão sincronizados com sua pele: não só eles “falam” da ocorrência de seus cortes, mas a cada automutilação infligida, um novo documento é redigido e juntado no seu processo disciplinar.

Essa sincronicidade dos papeis oficiais com seu corpo mobilizou-me a refletir não exatamente sobre o conteúdo que investe de significado seus cortes e queimaduras, mas para uma análoga sincronicidade do meu caderninho com Daiana. A cada novo encontro, uma nova conversa era impressa ou no meu caderninho ou na memória, numa tentativa de "emprestar meu corpo para a experiência do outro" como um "corpo de escrita" (CAVELL, apud DAS, 2007:41, tradução minha) ${ }^{33}$. No entanto, essa tentativa culminou

\footnotetext{
33 "My knowledge of myself is something I find, as on a successful quest; my knowledge of others, of their separateness from me, is something that finds me...And it seems reasonable to me, and illuminating,
} 
menos em conhecer quem é Daiana do que as limitações da própria "camada de interface", cujas lacunas e impossibilidades de conhecimento constroem uma relação de contundente assimetria no contexto de uma "pastoral da escuta".

Como, então, essa assimetria impacta no imperativo de "escutar"? Onde a história de Daiana ganha ressonância? O Relatório Tortura talvez dê algumas pistas para começar. Um de seus parágrafos introdutórios faz a costura entre $\mathrm{PCr}$ e a prática de identificar e denunciar torturas:

\begin{abstract}
A Pastoral Carcerária e a denúncia de tortura no sistema prisional estão intimamente ligadas. Não é possível visitar uma unidade prisional, ver o que ocorre no seu interior e ficar indiferente. Calar, ficar em silêncio e compactuar com as irregularidades é negar o próprio objetivo da Pastoral Carcerária: evangelizar e ser a presença da Igreja de Jesus Cristo no cárcere (Relatório Tortura, 2018:13).
\end{abstract}

Adiante, uma referência a Pe. Francisco Reardon, antigo coordenador nacional da PCr e conhecido afetuosamente como Pe. Chico:

\begin{abstract}
Ele [Pe Chico] comparava a ação dos agentes da Pastoral Carcerária como um barco que segue contra a maré da opinião pública, nas igrejas e na sociedade, tentando defender a vida, a dignidade e a integridade física e moral dos presos, porque, segundo ele, "a nossa voz e a nossa luta é o eco e vestígio dos marginalizados" (ibid).
\end{abstract}

Os dois excertos sugerem uma forte relação entre o trabalho pastoral e o de uma espécie de mensageiro, cuja carga em seu barco é composta de "ecos" e "vestígios" de outros. Com efeito, uma categoria mobilizada com recorrência no âmbito da $\mathrm{PCr}$ foi "testemunho". Em retiro espiritual da PCr realizado a nível arquidiocesano, uma senhora assim definiu a "missão pastoral": "muito do nosso trabalho é resistir e testemunhar". Nesse mesmo retiro, uma das palestrantes convidadas foi uma freira com uma longa trajetória de trabalho junto ao Movimento dos Trabalhadores sem Terra (MST), quem nos foi apresentada como um "livro vivo, não na estante".

Um certo exemplo de "ser" pastoral parecia ser dado naquela apresentação. Testemunhar uma "realidade" de nada vale se o que foi visto e ouvido não for levado adiante. O Relatório Tortura é elucidativo no que concerne ao fluxo por onde percorre o testemunho: as denúncias de maus tratos ou tortura registradas pelos agentes pastorais são levadas para seus coordenadores regionais que, por sua vez, transmitem ao Escritório Nacional. Esse último encaminha para "órgãos competentes do Poder Judiciário da

to speak of that reception of impression as my lending my body to the other's experience. The plainest manifestation of this responsiveness may be taken to be its effect on a body of writing" (ibid) 
União, dos Estados, Ministério Público Estadual, Defensoria Pública do Estado, CNPCP, DEPEN, CNJ, STF” (Relatório Tortura, 2018:17). Quando esses órgãos resultam ineficazes, instâncias internacionais são acionadas, como Anistia Internacional, ONU e Corte Interamericana de Direitos Humanos. Além desse fluxo jurídico, existem participações da PCr em eventos sobre encarceramento, cujos convites se devem ao peso político dessa organização na veiculação de dados e informações sobre essa temática.

Penso, então, em que medida nossos caderninhos, nos quais foram grafadas muitas palavras, ou pedaços delas, são portadores de "vida" pelo fato de as terem levado a outros planos, sobretudo por ter servido de substrato para o Relatório Hospitais-Prisão; um relatório público, sobre o qual nossa maior expectativa, enquanto GT, era que circulasse e fosse lido na maior escala possível. Embora ele tenha sido lançado, o testemunho que lhe permitiu "sair da estante" é o que lhe faz "vivo"?

Investigando o que chama de "governo humanitário", Fassin (2012) identifica um paradoxo que marca as organizações humanitárias contemporâneas. Quando retrocede ao nascimento do Comitê Internacional da Cruz Vermelha (CICV) em 1870, ele pontua que a provisão de ajuda estava associada ao "silêncio", na medida em que um dos princípios basilares de sua atuação era a neutralidade política nos conflitos bélicos. Já para as organizações mais recentes, cujos exemplos são Médecins Sans Frontières e Médecins $d u$ Monde, há uma inversão desse princípio em direção à publicização de violências, ancorada numa linguagem “compassiva”. Essa inversão pressupõe também uma segunda inversão que lhe é decorrente, a saber, a produção de uma "testemunha", e aqui jaz o paradoxo, que privilegia um relato da "experiência" do que foi vivido, mas cujo relator não é aquele que a viveu, senão o de um terceiro que a testemunha (Fassin, 2012:206, tradução minha). Em suas palavras:

What counts is not that the event took place, but that it was
felt. It is not the fact in itself that constitutes the proof, but the
trace it leaves in the psyche or the mark it makes in the telling.
In the testimony that is brought to the world's awareness,
affect is present both as that which bears witness (people's
suffering) and as that which is produced by the testimony (the
compassion of the public). The truth sought is not the objective
truth of the events that occurred, but the subjective truth of the
experience of them (ibid:208).

Nessa linguagem da experiência, o que é ouvido ganha preponderância sobre o que é visto por parte dos profissionais de ajuda humanitária, que produz um "sujeito do sofrimento" (:218, tradução minha). Isso parece ir ao encontro de uma justificativa 
presente no Relatório Tortura, referente ao porquê de ser importante visitar unidades prisionais:

Mesmo sem ser um mecanismo formal de monitoramento e fiscalização do sistema carcerário brasileiro, a Pastoral Carcerária historicamente foi capaz de prover uma visão reconhecidamente única desta complexa e degradante realidade, que se distingue consideravelmente das abordagens puramente acadêmicas, administrativas ou jurídicas sobre o tema.

Tal fato se dá não apenas pela seriedade e capilaridade nacional do trabalho realizado pelo conjunto da organização, mas também pela presença constante no cárcere, o que possibilita a construção de vínculos reais de solidariedade com os presos e seus familiares, bem como uma interlocução rotineira com agentes penitenciários, dirigentes políticos, e as autoridades do sistema de justiça.

Essa presença se viabiliza em razão do exercício da assistência religiosa e humanitária aos encarcerados, que, longe de ser uma atividade meramente voluntária ou cuja realização se encontra no campo da discricionariedade da administração penitenciária, é uma obrigação do Estado e um direito do preso que se concretiza pela ação dos representantes de igrejas e grupos religiosos (Relatório Tortura, 2018:36).

A evocação de uma noção de "vínculo" está diretamente relacionada com o imperativo de estar presente, inferindo uma posição de testemunha e de mediador das relações que giram em torno do sistema carcerário, tanto a nível das pessoas, quanto de órgãos estatais.

É justamente essa posição de testemunho que, amparado numa abordagem foucaultiana, Fassin (2012) coloca sob escrutínio, esmiuçando o tipo de subjetivação que é produzida a partir dessa nova relação estabelecida entre organizações humanitárias e seu público alvo. Para ele, tal relação, de gramática moral e afeita mais à mobilização de noções de "compaixão" do que de "justiça", constrói o que chama de "política da compaixão", a qual não só “excede o Estado”, mas impinge uma posição inexoravelmente desigual entre os atores em jogo, a fim de "contar uma verdade através do outro". A seu ver, portanto, “a política da compaixão é uma política da desigualdade”, uma vez que, "independentemente das boas intenções dos agentes, faz da compaixão um sentimento moral sem qualquer possibilidade de reciprocidade" (Fassin, 2012:3, tradução minha).

O seio de sua crítica, portanto, reside numa despolitização dos conflitos sociais, resultante do ofuscamento causado pela redução do debate humanitário à morte e ao sofrimento produzidos, sobretudo pelo emprego da linguagem que transforma uma violência sofrida em "trauma". Ainda que a linguagem da $\mathrm{PCr}$ não opere com um vocabulário estritamente psicológico ou não prescinda de noções de "justiça social", procuro argumentar que não se trata de afirmar que ela despolitiza o debate sobre 
encarceramento. Os documentos da $\mathrm{PCr}$ são evidência do contrário, isto é, de uma discussão altamente politizada. No entanto, ao mesmo tempo, ela combina de maneira particular uma linguagem de compaixão religiosa à gramatica jurídico humanitária de legislações nacionais e internacionais da seara dos Direitos Humanos. Sem talvez bipolarizar os termos entre "humanitário" e "político", creio que o principal intuito de Fassin seja o de demonstrar, justamente, a imbricação entre eles, que formata um determinado modo de como contar a experiência.

O entrecruzamento entre linguagem e ativismo em interface com moralidade é também um tema sobre o qual se debruça Maria Claudia Coelho. Em seu artigo Três mulheres no nazismo: reflexões sobra as fontes do comportamento moral (2010), a autora discute, além dos casos da secretária, Traudl Junge, e da cineasta, Leni Riefenstahl, de Hitler, o caso da jovem ativista Sophie Scholl, presa por espalhar panfletos contra o regime nazista em sua universidade. Embora sua fonte de análise seja um romance sobre a vida de Scholl, a ficção não invalida uma discussão sobre "lei" e "consciência" para a qual a autora faz interessantes aproximações com o pensamento de Hannah Arendt.

Definindo sua panfletagem como uma tentativa de convencimento das pessoas com palavras, a personagem defende sua posição perante um oficial nazista alegando que se recusava a seguir uma lei que atentasse contra o direito individual, apelando para sua própria consciência. Para Coelho, o ponto central de sua defesa, e que vai ao encontro do pensamento de Arendt, é que Scholl se recusa a consentir com um regime legal que fere o direito de liberdade; ela ousou a "pensar por conta própria", em detrimento do "conforto" de seguir os outros. Para a filósofa alemã, obedecer à lei nazista era, na verdade, consentir com a brutalidade, pressupondo um poder de escolha individual, atitude essa baseada numa "moral" capaz de operar a distinção entre certo/errado e que primasse pela liberdade (Coelho,2010:37).

Se fizermos o exercício de pensar no Relatório Hospitais-Prisão como uma panfletagem, no paralelo funcional de transpor espaços e "persuadir com palavras", podemos entendê-lo como uma tentativa de contar uma história dos manicômios judiciários e dos(as) que habitam seu interior partindo de suas "narrativas". Entretanto, não era exatamente uma tentativa de opor "lei" e "consciência", uma vez que o relatório também lança mão de um discurso legal balizador de sua proposta abolicionista penal, como por exemplo a Lei 10.216/2001, a qual instaura a reforma psiquiátrica brasileira, em rechaço ao paradigma manicomial. Ou seja, nortear-se por essa diretriz política não 
significa abdicar de todo e qualquer mecanismo legal e tampouco das instâncias estatais. O ponto central do texto era demonstrar as limitações de uma militância que busca exclusivamente na lei a resolução de problemas. Nesse sentido, a permanência dos hospitais psiquiátricos a despeito da Lei 10.216/2001, que completa quase vinte anos, mostram as limitações dessa perspectiva política.

Diante dessas considerações e no que concerne ao caso de Daiana, buscar a "palavra" da lei ou confrontá-la, como se navegássemos nosso barco "contra a maré tendo nossa "consciência" como leme não parecia ser o caminho a ser escolhido de modo a reverberar sua história. Esse impasse é o que torna a particularidade de seu caso relevante de ser reiterada porque é um exemplo de quando, a partir do testemunho como base legitimadora da presença, nem a "Palavra" - "parte religiosa" - nem a "palavra" "parte social”, parecem dar conta da complexidade que essa relação impõe. Não havia conforto ou encaminhamento prático a ser fornecido por nenhuma das palavras para que ela fosse "feliz", sentimento esse oriundo somente de seus cortes e queimaduras. Como consequência, isso colocou um obstáculo na própria condição tanto de transmissão da "narrativa" quanto no seu potencial de "ressonância". Ao mesmo tempo que ela se fazia presente pelos papeis que nos conectavam, sobretudo a partir do meu caderninho como mediador dessa relação, era como se sua história seguisse sempre obliterada, inacessível; uma presença constantemente ausente. Em outras palavras, o ponto nodal que o caso de Daiana interpela frente à escuta que busca "um mundo sem cárceres" é o paradoxo da "transmissão inenarrável" ou da história "predicada na impossibilidade" de ser contada (Hartman, 2008:2).

Algumas dessas questões me parecem próximas às da historiadora estadunidense Saidiya Hartman ao investigar os arquivos históricos setecentistas da travessia atlântica dos navios negreiros com destino aos Estados Unidos, travessia essa conhecida como "Middle Passage" (ibid:25, tradução minha). Ao escrever sobre esses documentos, ela digladia com o apagamento de uma mulher escravizada de nome Vênus, cuja referência aparece nos registros do navio "Recovery" em travessia feita no ano de 1792. A extremamente escassa informação a respeito de sua vida não é entendida, pela autora, como uma falha de registro, mas como evidência de uma dupla violência. As vidas dizimadas pela violência da escravidão, normalizada durante séculos de tráfico, estão intrinsecamente relacionadas à violência do apagamento documental, o qual desumaniza as existências por referenciá-las não como humanos, mas como mercadorias. 
É impossível, segundo Hartman, conhecer a história Vênus e arriscar-se a recontar uma história total através de fragmentos, preenchendo suas lacunas, o que seria, inevitavelmente, reproduzir a violência que os próprios arquivos encerram.

\begin{abstract}
One cannot ask, "Who is Venus?" because it would be impossible to answer such a question. There are hundreds of thousands of other girls who share her circumstances and these circumstances have generated few stories. And the stories that exist are not about them, but rather about the violence, excess, mendacity, and reason that seized hold of their lives, transformed them into commodities and corpses, and identified them with names tossed-off as insults and crass jokes. The archive is, in this case, a death sentence, a tomb, a display of the violated body, an inventory of property, a medical treatise on gonorrhea, a few lines about a whore's life, an asterisk in the grand narrative of history. Given this, "it is doubtless impossible to ever grasp [these lives] again in themselves, as they might have been 'in a free state (Hartman, 2008:2).
\end{abstract}

Embora não haja uma lacuna temporal de séculos que me aparta de Daiana, como no caso de Hartman e Vênus, gostaria de ajustar o foco sobre o equívoco que a leitura do processo penal acabou me mostrando com relação ao meu objetivo de sua busca. Assim, menos do que buscar encontrar "a" Daiana, num sentido talvez quase que psiquiátrico e reprodutor da gramática moral dos laudos, ou buscar conhecer uma Daiana prévia ao nosso primeiro encontro ou à sua custódia no HCTP, desloco a perspectiva para "ver" a relação que era por nós forjada, para como éramos construídos no momento da interação, inserida na dobra entre PCr e HCTP e refletida também nos papeis de laudos e caderninhos, cujas margens, sob determinadas angulações, mesclam-se, confundem-se.

“Como revisitar a cena de sujeição sem replicar a gramática de violência?”. Para responder essa pergunta, Hartman entende que deve furtar-se à "tentação" de "preencher as lacunas e dar um fechamento onde ele não é possível" uma vez que, se, como ela mesma defende, navio negreiro e textualidade estão temporalmente implicados, ir além dos "números, cifras e fragmentos de discurso" dos arquivos seria cair no equívoco de negar a existência da violência que fez dela mercadoria. Por outro lado, sua escolha de refrear a tentação não resolve o dilema de que, ao ousar contar a história de Vênus, restalhe apenas a inescapável tarefa de reproduzir "as cenas de violência" que marcam a experiência de "negritude" (ibid:4, tradução minha). Sua intenção, portanto, pode ser resumida no paradoxo de "contar tanto uma história impossível quanto amplificar a impossibilidade de contá-la" (ibid:11, tradução minha).

Com todas as ressalvas que diferenciam o escopo temático de nossas pesquisas, acredito que suas ideias sejam rentáveis para perscrutar o paradoxo do trabalho de 
testemunho pastoral. Ao mobilizar-se pelo imperativo de ressoar "relatos tradicionalmente silenciados pelos muros prisionais" na concretização de "um mundo sem cárceres", o testemunho ignora as próprias grades epistêmicas que formatam a experiência de estar junto aos que "sofrem e padecem". As clivagens de classe, raça e gênero, presentes corporalmente em meus encontros com Daiana e, de modo mais abrangente, incrustrados nas tramas que enleiam PCr e HTCPs, residem invisibilizadas e silenciadas quando se promulga o dever de "ver" e escutar sem que o próprio contexto do encontro, isto é, as múltiplas desigualdades que lhe dão forma, seja colocado em questão. Tal dilema, vale ressaltar, não se vincula a uma ou outra concepção de testemunho como vemos no episódio da nota e contra nota. A despeito do antagonismo institucional que os documentos produzem, bem como das semânticas em torno da importância das visitas, a contextualização e visibilização dessas clivagens permanece um debate intocado.

A politização que procuro ao visibilizar a relação do testemunho tal como promovida pela $\mathrm{PCr}$, não deve ser algo que aprisione ou imobilize a "pastoral da escuta", reivindicando sua extinção. Hartman, por exemplo, não se furta da tentativa de contar a história de Vênus, porém o faz sem perder de vista a recondução, em seu próprio ato de narrar, das violências que lhe transformaram em mercadoria, a despeito de sua vontade, enquanto historiadora, de querer concebê-la como humana. Em paralelo, acredito ser essencial o enfrentamento ao dilema que a relação com Daiana impõe, ou seja, reconhecer a impossibilidade de conhecê-la, a fim de lidar com o fazer ver das desigualdades institucionais em jogo e as violências que lhe são imanentes quando nos concebemos capazes de "ver", "julgar” e "agir" em histórias consideradas silenciadas.

“Caio, você sabe que é meu amigo, né? Não esquece de anotar no caderninho!"

Neste capítulo, procurei dar prioridade ao trabalho de testemunho, enfocando em como a ideia de "pastoral da escuta" foi peça chave, em suas ambiguidades e contradições, no que culminou no Relatório Hospitais-Prisão. Além disso, almejei demonstrar como sua metodologia e objetivos não se fazem dissociados dos propósitos teológico-morais de construir "um mundo sem cárceres", eixo primordial da PCr.

No capítulo seguinte, deter-me-ei no processo de escrita das muitas escutas que foram recolhidas, procurando, também, entendê-lo como parte da diretriz penal- 
abolicionista do GT e, de modo mais geral, da PCr. Procuro discutir como essa escrita concretizou-se como escolha de enfrentamento a uma moral mobilizada tanto pelo corpo funcional dos HCTPs quanto pela máquina judiciária, colocando desafios específicos para sua redação. 


\title{
Capítulo 2: A tentativa de escrever histórias
}

\author{
(...) mais difícil tarefa é de exumar as vidas \\ enterradas debaixo dessa prosa (...) (Hartman, \\ 2008:6, tradução minha).
}

A primeira visita pastoral realizada pelo GT após o lançamento do relatório não foi menos tensa àquela que o precedeu. Chegando à diretoria do HCTP, o diretor nos precaveu que o corpo funcional estava resistente à nossa presença uma vez que entendiam o material publicado como afrontoso ao trabalho por eles desempenhado. Embora já esperássemos uma reação hostil, estávamos nervosos para encontrar os(as) funcionários(as), alguns dos(as) quais já nos conheciam de modo mais particular do que muitos(as) pacientes-detentos(as).

Chegando à ala feminina do HCTP, nosso primeiro ponto de parada naquele dia, a enfermeira-chefe do setor pediu que, antes de fazermos a costumeira visita com as mulheres ali custodiadas, nos reuníssemos numa das salas adjacente ao corredor que desemboca no pátio interno, pois as enfermeiras gostariam de falar conosco. Assentimos e calmamente nos dirigimos à pequena sala margeada de estantes repletas de medicamentos, dispostas em duas das paredes do ambiente retangular. A mesa, ao centro, era o que nos dividia com algumas das enfermeiras que trabalhavam na ala, as quais estavam dispostas de pé e rente à parede. Assim que entramos percebemos o peso do tenso silêncio que acompanhou nossa entrada, o qual só foi rompido com a palavra da enfermeira-chefe, pedindo que explicássemos por que havíamos escrito o relatório.

Replicamos dizendo que, antes de falar sobre o relatório, gostaríamos de ouvi-las para entender melhor suas opiniões e impressões a respeito do que achavam de seu conteúdo; suas críticas, objeções e comentários. A primeira a se pronunciar entre as profissionais quebrou um segundo silêncio, mais breve, porém não menos constrangedor, que imperou entre nosso convite e o começo dos pronunciamentos. Sua fala colocou o relatório como um "desrespeito" a um trabalho cujo início era muito precedente à nossa chegada ao HCTP, que passava ao largo do cuidado e atenção despendidos aos(às) custodiados(as) diariamente. Em sequência, sublinhou que nossa presença quinzenal era demasiada pontual de modo a subsidiar tanto uma assistência apropriada quanto a criticar o trabalho para o qual elas haviam diploma universitário e experiência profissional. E, 
como exemplo, lembrou-me de uma determinada visita que eu, após ouvir a queixa de otite de uma das pacientes-detentas, dirigi-me a ela para perguntar-lhe se estava ciente da infecção que acabara de ouvir a respeito. Nas palavras dela, minha pergunta soava “ofensiva”, uma vez que não seria razoável pressupor que ela, na posição de enfermeira, não estivesse a par de uma questão de saúde da ala de sua competência. Ainda referindose à "paciente", disse que nossa curta e esporádica presença enquanto GT não era capaz de dimensionar o estado em que se encontrava quando veio transferida do CDP Feminino de Franco da Rocha, presídio que opera alas psiquiátricas em seu interior. Seu trabalho de enfermagem desde a chegada da "paciente", segundo ela, havia melhorado sobremaneira seu estado de saúde. Por último, reiterou que, embora achasse "bonito" nossa disposição de "ajudar" aquelas pessoas, isso não nos dava o direito de criticar o trabalho cotidiano e minucioso, o qual contrastava com o esporádico de nossa presença, ressaltando ainda que algumas enfermeiras propositalmente se abstiveram de estar naquela conversa por se sentirem pessoalmente afrontadas.

Enquanto ouvíamos suas palavras em silêncio, notei que as outras assentiam com a cabeça, como a concordar com sua opinião. Uma vez terminada sua fala, algumas outras se colocaram também reiterando o sentimento de ofensa ao ofício de enfermagem, que compreendia não apenas prover assistência médica, mas conhecer suas "pacientes", em suas necessidades e vulnerabilidades.

Chegada nossa vez de falar, embora nos alternássemos para complementar mutuamente nossas tentativas de resposta, buscamos centrar no ponto que foi norteador do texto do relatório, a saber, um conceito de violência que não se limitava ao exercício individual desse(a) ou daquele(a) funcionário(a) e que tampouco se vinculasse a uma profissão em específico. Desde esse ponto de vista, não estariam em questão condutas e práticas, mas o contexto prisional-manicomial em que elas se encontram e como se conjugam a fim de legitimar o encarceramento, qual se este fosse terapêutico. Como tentamos argumentar, em nenhum momento do relatório defendemos envidar esforços para a substituição de funcionários ou a extinção de uma área do saber, pois isso seria reduzir a questão dos HCTPs a um problema de competência profissional ou defasagem de infraestrutura, como se a solução fosse aprimoramento. Ao contrário, compreendíamos que a dedicação profissional com que se empenhavam seria mais benéfica se fosse realizada em outros espaços, não conformados pelas "lógicas manicomiais-prisionais", como escrevemos no relatório, das quais os HCTPs são apenas uma parte. 
Foi interessante notar que, embora ainda não o tivessem lido, como elas mesmas afirmaram quando fizemos essa pergunta, o modo como a notícia de seu lançamento circulou, bem como seu conhecimento do GT pelas visitas que fazíamos, promoveu uma prévia concepção do seu conteúdo que foi decisiva para impactar a relação que tínhamos com o corpo funcional. Sublinho, então, que não necessariamente os papeis precisam ser lidos para produzirem efeitos, já que a notícia de sua divulgação num evento de lançamento foi suficiente para que discutíssemos as ideias presentes no texto.

Com efeito, um de nossos pontos de discussão em reuniões do GT era a nossa interlocução com funcionários(as), uma vez que atuar em favor de pacientes-detentos(as) era por eles(as) frequentemente entendido a estar contra sua atuação profissional nos HCTPs. A esse respeito vale ressaltar a breve conversa que tivemos com um dos agentes de segurança que nos conduziu de carro quando saímos da ala feminina após essa visita.

Enquanto balançávamos ao ritmo da pequena estrada de terra trepidante que liga o prédio da ala feminina aos demais setores do HCTP, puxamos a conversa sobre o relatório com o agente de segurança que silenciosamente conduzia o veículo. Da mesma forma que na ala feminina, inquirimos sobre o que tinha ouvido falar do material, ao que ele respondeu com uma afirmação introdutória de que assim como nós tínhamos nosso trabalho, ele tinha o dele. Sem mencionar o texto diretamente, até porque ele tampouco o havia lido, assim continuou referindo-se à população custodiada: "é da gente que eles vão ouvir 'não', somos nós que temos que intervir porque estamos na linha de frente". A seguir, fez uma comparação ao presídio que havia trabalhado antes de ser transferido para o HCTP, dizendo que lá era "muito pior" devido à proibição de falar com os presos: "a massa não deixa" 34 , asseverou, ao passo que no HCTP a “área humana é maior”. Por fim, disse que na "vida real” é mais comum que ouçamos " "não' do que 'sim"”. "Nossa função é falar "não"”, reforçou.

Quando confortáveis para replicar, percebendo que ele tinha feito suas observações, dissemos que não queríamos modificar o trabalho de ninguém, mas questionar o porquê de ele ser feito dentro de um HCTP, fato que, como falamos na ala feminina, era muito mais complexo do que uma relação funcionário(a) - pacientedetento(a). Tanto no veículo quanto na ala feminina, sentimos que a conversa não chegou

\footnotetext{
${ }^{34}$ O termo "massa" refere-se à "massa carcerária", designando a população prisional que, em presídios controlados pelo PCC, obedece regras explícitas de como lidar com os agentes de segurança.
} 
a qualquer tipo de conciliação, embora tivéssemos considerado esses diálogos mais proveitosos frente ao que esperávamos em termos de hostilidade na primeira visita subsequente ao lançamento.

O último funcionário com quem conversamos naquele dia foi o coordenador da área educacional do HCTP, o qual respeitosamente perguntou se tínhamos sugestões ou considerações sobre o que poderia ser melhorado quanto à sua área de competência e pediu que ficássemos à vontade para fazê-las. Agradecemos o oferecimento dizendo que não nos sentíamos aptos para isso, procurando ressaltar que fugia dos nossos objetivos, com o relatório, tentativas de melhoramento do espaço pois não estávamos preocupados exatamente com as funções profissionais exercidas ali.

Durante as visitas, em geral, conversávamos com os funcionários "da ponta", como disse o agente de segurança, sem nunca termos falado com um médico psiquiatra ou clínico, e aquela visita não foi diferente. De todo modo, sabíamos que nossa presença ali não era vista com bons olhos vide o fato de que o próprio diretor advertiu que alguns dos(as) médicos consideravam acionar judicialmente contra o lançamento do relatório, via Conselho Regional de Medicina (CRM). Entretanto, é importante ressaltar que dificilmente o contato do GT com o corpo funcional dos HCTPs é entendido necessariamente a partir da lógica opositiva, até porque as formas de interlocução e as relações estabelecidas foram múltiplas.

O que gostaria de colocar em perspectiva, portanto, a partir do breve relato da visita subsequente ao lançamento do relatório, são os imperativos morais acionados em nome do cuidado e como essa categoria foi apreendida pelo GT na elaboração do relatório. Esse ponto, como procuro desenvolver adiante, é fundamental para a conceituação do termo "tortura" empregado no texto para justificar a linha abolicionistapenal, que vai contra a operação dessas instituições.

Se o caminho adotado para a construção deste relatório é o funcionamento das instituições "na ponta", ao longo do texto mobilizam-se narrativas de internos e funcionários, tendo como objetivo central conferir materialidade aos espaços descritos. A escolha por não identificar indivíduos se deve à leitura de que as mazelas observadas dentro dos muros não são de responsabilidade de uma ou outra pessoa, embora bem saibamos que determinadas condutas individuais - e aqui nos referimos ao corpo funcional - têm influência, por vezes decisiva, no destino das pessoas internadas. Porém, o enfoque aqui adotado privilegia as lógicas, as estruturas e os mecanismos que sustentam tais espaços (Relatório Hospitais-Prisão, 2018:14). 
O parágrafo acima transcrito sintetiza um esforço metodológico empreendido pelo GT de, por meio da escrita, alinhavar "narrativas" a "lógicas", "estruturas" e "mecanismos", a fim de "fazer ver" um plano que transcende "condutas individuais"; algo que opera além delas. Para isso, houve um esforço de colocar em relevo o que foi chamado no texto de "rede prisional-manicomial", mobilizando um conceito de "tortura" não-individualizante, preocupado com as múltiplas instituições tanto do sistema prisional quanto da RAPS (Rede de Atenção Psicossocial), por onde as pessoas em medida de segurança circulam.

A escolha desse olhar, contudo, sobretudo pela tentativa de despersonalização das relações institucionais, apresentou o desafio de lidar com o nosso papel de visitantes periódicos, enquanto GT, na conformação do que se nomeou, no relatório, como "rede". Com efeito, havia um intento, nas ações de atendimento às demandas realizadas nas visitas, de "não substituir o Estado nas suas atribuições básicas" "35, em consonância com um dos princípios basilares da $\mathrm{PCr}$, a fim de que não se busque a humanização do sistema carcerário, mas sua extinção (Relatório Tortura, 2018:49).

O cotidiano de visitas, porém, desestabilizava fronteiras entre substituição e oposição ao trabalho do Estado. O capítulo seguinte deter-se-á nos vários agenciamentos com o Estado que um trabalho contra ele mobiliza no plano cotidiano: veremos um exemplo de como a receptividade do setor de serviço social de um HCTP, juntamente com o contado estabelecido com a Defensoria Pública por meio do NESC, foram fatores importantes para os encaminhamentos de Mercedes, uma paciente-detenta. Meu interesse por enquanto, é salientar que, como agentes pastorais atuantes "na ponta”, assim como os(as) funcionários(as) - a despeito das devidas diferenciações qualificativas e temporais - devíamos nos confrontar com um dilema recorrentemente suscitado em nossas reuniões de grupo, a saber, o quanto somos "engrenagem" da "máquina" que desejamos pifar, palavras essas repetidamente proferidas nesses momentos em coletividade. Tal dilema era acionado, inclusive, nos pormenores desse cotidiano visitas, no qual o atendimento a um pedido de ligação telefônica a um familiar parecia estar menos a serviço da oposição do que da substituição às funções institucionais.

${ }^{35}$ A citação é proveniente de outro relatório redigido pela equipe do Escritório Nacional da PCr, publicado alguns meses depois do Relatório Hospitais-Prisão, com o título Tortura em Tempos de Encarceramento em Massa, doravante referido apenas como Relatório Tortura. 
O ponto central deste capítulo reside em mostrar, portanto, como o conceito de "tortura” proposto no Relatório Hospitais-Prisão está inexoravelmente conectado a uma forma de "ver" o que está por trás do dever de "dizer não", como um imperativo moral do cuidado que, mobilizado para fazer o bem, o GT tentou dar-lhe inteligibilidade desde um ponto de visto crítico, inserindo-o num contexto violador . Desse modo, a partir do relato de uma visita ao HCTP de Taubaté, almejo discutir como o que era visto e ouvido foi traduzido para a escrita do texto do relatório, num duplo movimento do "ver": o ângulo de nossa visão sobre o trabalho do Estado refletia o feixe de nossas próprias práticas, ou, dito de outro modo, interrogar o dever de "dizer não" era inevitavelmente interpelar o que está por trás do dever de uma ligação telefônica ou a consulta a um processo jurídico, trazendo para o foco as ambivalências e contradições do trabalho pastoral. Assim, colocarei sob escrutínio uma prática de escrita ancorada na experiência do testemunho que, a despeito de sua paradoxal contribuição nos deslizamentos entre conivência e resistência, se define como abolicionista penal ao defender "um mundo sem cárceres".

Como um primeiro passo, exponho resumidamente o surgimento das alas psiquiátricas em prisões, evento cujo entendimento se faz primordial para entender o que se chamou de "rede prisional-manicomial" no Relatório Hospitais-Prisão e como seu nascimento nas unidades prisionais é, ele próprio, resultado de motivações morais a fim de prover melhores condições à população em medida de segurança no Estado de São Paulo.

\section{Alas psiquiátricas em prisões}

\footnotetext{
Não é possível compreender o funcionamento dos HCTPs de São Paulo sem considerar os diversos espaços que, de maneiras variadas, se conectam a eles. Se, por um lado, o cumprimento da medida de segurança é marcado por longos períodos, que duram, por vezes, a vida toda, por outro, há trajetórias individuais que contemplam deslocamentos entre instituições, conformando uma espécie de rede prisional-manicomial (Relatório Hospitais-Prisão, 2018:41).
}

Como mencionado anteriormente, o fato de os Manicômios Judiciários não operarem em regime de superlotação faz com que exista uma fila de espera da população em medida de segurança, esta ou alocada em unidades penitenciárias paulistas ou cumprindo tratamento ambulatorial em meio aberto. Até o final de 2013, a parte dessa população privada de liberdade encontrava-se dispersa em diversas prisões do estado, fato 
esse considerado ilegal, uma vez que a absolvição imprópria é distinta da pena, isto é, a exaração da medida de segurança implica um regime de tratamento e não de punição ${ }^{36}$. Diante disso, o NESC/DP-SP realizou a impetração em massa de Habeas Corpus, com base no argumento jurídico de que, dada a indisponibilidade de vagas em HCTPs, às pessoas em espera deveria ser concedido tratamento ambulatorial em meio aberto. $\mathrm{O}$ principal argumento utilizado era que a alocação de pessoas portadoras de condições psiquiátricas delicadas, em suposta condição de tratamento, não devem ser submetidas ao regime prisional comum, tal como estipula tanto a Lei de Execução Penal (LEP) - Lei 7.210/84 - quanto o Código Penal (CP), além de ser uma violação à Súmula vinculante 56 do Supremo Tribunal Federal, a qual estabelece que "a falta de estabelecimento penal adequado não autoriza a manutenção do condenado em regime prisional mais gravoso"$^{137}$.

A mobilização jurídica empreendida, portanto, envolveu o acionamento individualizado referente ao processo penal de aproximadamente 500 pessoas, requisitando o laudo de cessação de periculosidade e, em caso de manutenção de permanência da periculosidade, a imediata determinação de tratamento ambulatorial. $\mathrm{O}$ desafio consistia em lidar, tal como os defensores públicos envolvidos nessa ação entendiam, com uma dupla ilegalidade: levando em conta a reforma psiquiátrica de 2001, para a qual a promulgação da lei 10216/2001 é um divisor de águas ao extinguir o paradigma manicomial das políticas de saúde mental, os HCTPs são totalmente ilegais. Como se isso não bastasse, o cerne da espinhosa questão residia também no fato de que a manutenção da população de medida de segurança em prisões era também um fato ilegal (Barros, 2018:79).

A fim de que a iniciativa tivesse efeito, o elevado número de impetrações teria que ser realizado num período curto de tempo: de uma a duas semanas. Como as tentativas anteriores de decrescerem esse número a partir dessa mesma estratégia resultaram ineficazes devido ao ritmo desacelerado de impetrações de HC frente ao crescimento da fila de espera, o cartório da $5^{\text {a } V E C, ~ r e s p o n s a ́ v e l ~ p e l o s ~ p r o c e s s o s ~ d e ~ e x e c u c ̧ a ̃ o ~ d a s ~ m e d i d a s ~}$ de segurança, recebeu $500 \mathrm{HCs}$ no intervalo de quinze dias, o que inviabilizou o trabalho

\footnotetext{
${ }^{36}$ O relatório Hospitais-Prisão traz o dado de que, no Estado de São Paulo, nessa época, havia 1400 pessoas cumprindo medida de segurança em âmbito externo aos HCTPs e, dentre essas, aproximadamente 500 cumprindo tratamento ambulatorial (Relatório Hospitais-Prisão, 2018:41).

${ }^{37}$ Fonte: http://www.stf.jus.br/portal/jurisprudencia/menuSumario.asp?sumula=3352
} 
dessa instância. O objetivo central, segundo um dos defensores públicos participantes dessa ação, era justamente "quebrar", em suas palavras, o cartório, colocando em evidência uma situação calamitosa que demandava a instauração de uma política pública referente a essa população, a qual deveria excluir os HCTPs como alternativas viáveis (ibid:79).

Contra suas expectativas, no entanto, em abril de 2014 o NESC é notificado pelo judiciário de que os HCs foram julgados prejudicados, isto é, sem razão de ser, uma vez que os "pacientes" encontravam-se alocados em lugar adequado, a saber, em alas específicas de algumas unidades penitenciárias, com destaque para a PIII de Franco da Rocha, a qual havia sido esvaziada em dois de seus pavilhões para comportar, exclusivamente, pacientes psiquiátricos. O que temos, então, a partir desse momento, é não somente uma concentração dos processos de medida de segurança em uma única VEC, como também uma concentração dos corpos, a cujos papeis jurídicos remetem, em determinados espaços. A PIII, nesse cenário, acabou ganhando relevância tanto pelo volume de pacientes-detentos ali custodiados, aguardando vaga nos manicômios judiciários, quanto por sua proximidade geográfica com os dois HCTPs de Franco da Rocha, permitindo intensos fluxos de funcionários(as) e custodiados(as) entre as duas instituições (Relatório Hospitais-Prisão, 2018:42).

A surpresa com que a notícia da inefetividade da ação do NESC foi recebida deveu-se, sobretudo, ao fato de que a inauguração de alas psiquiátricas em presídios também inaugurou uma legalidade dentro da ilegalidade. Em outras palavras, tais espaços institucionalizaram a permanência de pacientes-detentos(as) em unidades penitenciárias, fato ilegal na letra da lei, e efetivado em detrimento de alternativas terapêuticas em meio ambulatorial aberto. Tamanho foi o respaldo institucional que essas alas receberam que a criação das alas na PIII juntamente com uma equipe robusta de peritos para a realização de laudos de cessação de periculosidade rendeu, na categoria "Justiça e Cidadania", o prêmio Innovare de 2016, sob o título "Projeto de Psiquiatria Forense e Psicologia Jurídica do Estado de São Paulo"38 (Barros, 2018:106; Relatório Hospitais-Prisão, 2018:43).

${ }^{38} \mathrm{O}$ Instituto Innovare é uma associação sem fins lucrativos cujo principal objetivo é premiar boas práticas em relação ao melhor funcionamento ou transparência do sistema de justiça brasileiro. Para ver mais detalhes, acessar: http://www.premioinnovare.com.br/media/imprensa/vencedoras-da-13aedicao-dopremio-innovare 
A situação perante a qual o NESC se deparou nos dá algumas pistas em relação a um embate de Estado vs. Estado, o qual ultrapassa a "completude e totalização que a ideia de Estado carrega" (Souza Lima, 2012:563). Embora ambas sejam instituições estatais do sistema de justiça, o que parece interessante notar é um movimento de oposição no qual o NESC, como sugere o emprego do termo "quebrar" por um dos defensores, envidou esforços para visibilizar uma ilegalidade através da intenção de obstaculizar o funcionamento ordinário da $5^{\mathrm{a}} \mathrm{VEC}$ lançando mão da massiva impetração de $\mathrm{HCs}$ em curto período de tempo. Embora não tenha sido uma estratégia bem-sucedida, fica clara a combinação entre celeridade e redação de papeis como fatores essenciais na condução desse objetivo.

\section{Conjugando compaixão e repressão}

A importância de retraçar brevemente esse panorama histórico que antecedeu a criação do GT de Saúde Mental e Liberdade deve-se tanto a reforçar que a problemática das medidas de segurança e dos manicômios judiciários transcendem seus muros quanto a evidenciar uma certa gramática moral que permitiu sua institucionalização, revestida com a camada de legitimidade pela premiação do Instituto Innovare. Diante da nefasta realidade de alocação de pacientes psiquiátricos em unidades penitenciárias, enfrentando uma série de vulnerabilidades e precariedades desses espaços, incluindo também o fator pernicioso de atrasos exorbitantes na realização de exames de cessação de periculosidade, a equipe premiada pelo Innovare teve um imperativo humanitário como um motivador

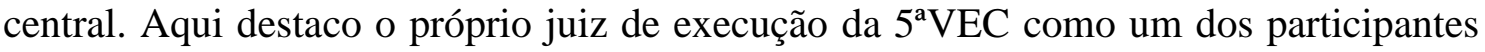
desse projeto, cuja coordenação foi exercida por um psiquiatra forense e que, nas palavras do referido juiz, não teria sido possível sem a parceria entre o Poder Executivo, na figura da SAP, e o Judiciário, representado pela $5^{\text {a }} \mathrm{VEC}^{39}$.

A lógica subjacente à iniciativa estava fortemente ancorada na provisão de assistência e aceleração dos processos de avaliação psiquiátrica, a fim de, a um só tempo, reduzir a fila de espera para os HCTPs e prover condições adequadas de vivência aos que aguardavam serem transferidos (Barros, 2018:81). Entretanto, não obstante os distintos entendimentos que nortearam tanto as ações do NESC, este visando o tratamento em meio

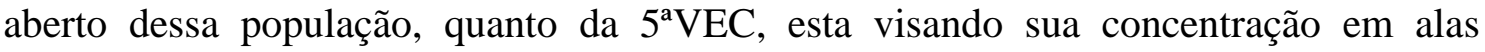

\footnotetext{
${ }^{39}$ Fonte: https://tj-sp.jusbrasil.com.br/noticias/413252019/sao-paulo-e-vencedor-do-13o-premio-
} innovare 
psiquiátricas, um substrato moral comum a ambos se faz combustível desses enfrentamentos.

O que se coloca como questão, portanto, é a emergência de um novo mecanismo de encarceramento legitimado por uma "razão humanitária" (Fassin, 2011). Com efeito, isso não deve soar estranho quando lembramos com Foucault (1977) que a própria emergência da prisão é tributária da humanização da punição, marcada pelo deslocamento de práticas de suplício, centradas majoritariamente sobre o corpo, a práticas punitivas regidas pela disciplina, esta enfocada nos sujeitos. Tal deslocamento, como bem ressalta o autor, não se faz descolado da emergência de uma moralidade operante sobre os sujeitos condenados e que pretendo recuperar mais adiante. O que parece patente em sua análise genealógica, no entanto, está longe de ser a afirmativa de uma atenuação do poder, mas uma sofisticação deste, produtor de subjetividades e preocupado antes com a figura do criminoso do que com o crime.

Essa chave analítica é de extrema importância para entender como, do ponto de vista do que defendíamos na linha penal-abolicionista, no âmbito na $\mathrm{PCr}$ e, mais especificamente, do GT, devíamos lidar com os discursos legitimadores desses espaços. A estabilização das alas psiquiátricas, portanto, era antes o reforço do que um arrefecimento das "lógicas manicomiais-prisionais" que, sob o manto do devido andamento dos processos de execução penal e do bem-estar dessa população, não coloca sub judice a própria existência de espaços encarceradores e tampouco contribui para seu esvaziamento, senão para seu aperfeiçoamento. Nesse sentido, o GT e o NESC tiveram interlocuções respaldadas pelo compartilhamento de uma diretriz política direcionada ao esvaziamento dessas alas, bem como dos HCTPs, reconhecendo a total marginalidade legal da custódia de pacientes-detentos(as) em unidades penitenciárias, porquanto sua existência jamais fora prevista na letra da lei. Esse compartilhamento de uma visão política sobre os HCTPs, bem como em relação às alas psiquiátricas, fomentou um contínuo diálogo entre as duas organizações e que também justifica sua participação no evento de lançamento do Relatório Hospitais-Prisão.

Dado esse panorama, ajusto o foco para uma análise que se assenta num dos pontos centrais do Relatório Hospitais-Prisão e que propugna a diretriz penalabolicionista orientadora de sua escrita. Refiro-me ao fato de que a violência do encarceramento contra a qual a PCr se posiciona não é necessariamente refratária a uma 
lógica humanitária que respalda a existência de espaços como presídios e manicômios judiciários, bem como outros equipamentos de política pública que se conectam de diversas formas com tais instituições a partir da reprodução de "lógicas manicomiaisprisionais". A esse respeito, não posso deixar de fazer referência ao trabalho de Adalton Marques (2018), no qual o autor analisa a emergência de uma razão democrática e humanista na seara da segurança pública em São Paulo a partir do final dos anos 70. Como o autor argumenta, a penetração de um discurso afeito à observância aos direitos humanos no domínio da política pública é justamente a lógica propulsora, e não contentiva, da expansão do sistema carcerário paulista ${ }^{40}$.

Desse modo, é possível dizer que "ver" os HCTPs como locais de exercício da violência não era de modo algum autoevidente, sobretudo pelo fato de sua proximidade com preocupações humanitárias que, constantemente, os legitimavam. Antes, justificar o fechamento de portas de entrada e o alargamento das de saída dependia de delicadas negociações e discussões de circunscrever práticas de cuidado biomédico, espaços bem equipados do ponto de vista técnico-assistencial e dotados de salubridade dentro de um campo conceitual de violência. Em uma palavra: se houve uma suposta melhora de fluxos entre HCTPs e presídios, assim como de infraestrutura técnica, como encaixar a ideia de "violência" a serviço da extinção desses locais?

Voltando à visita subsequente ao lançamento do relatório e à discussão travada com funcionários, podemos identificar uma possível aproximação com o histórico de criação das alas psiquiátricas na PIII. A intencionalidade tanto do corpo funcional do HCTP quanto do projeto premiado pelo Instituto Innovare não parece estar motivada pelo exercício do ódio, mas justamente por uma certa base de "compaixão" (Fassin, 2005) para com a população em medida de segurança. Seja pelo acionamento do discurso de melhor funcionamento para dar solução à pulverização de pessoas em medida de segurança por vários presídios paulistas ou pelo melhor bem-estar aos(às) custodiados(as), temos a institucionalização de espaços de asilamento (alas psiquiátricas e HCTPs) a despeito da legislação existente, fazendo, da exceção, a lei.

40 É importante ressaltar o papel que a Igreja Católica teve nesse processo de expansão, notadamente a Comissão Justiça e Paz (CJP) da Igreja Católica em torno do cardeal Dom Paulo Evaristo Arns como um dos atores que, como aponta Marques, colaborou para a conjunção de imperativos democrático-humanitários na conformação de políticas de segurança pública do Estado de São Paulo (Marques, 2018). 
Outra aproximação possível entre esses casos refere-se ao manejo de uma certa temporalidade que parece também operar como fator legitimador. Ao falar que a condição de saúde da "paciente" era muito pior do que quando a vi com otite, a enfermeira colocava valorosamente o tempo despendido no exercício de seu ofício e o resultado desse trabalho como contra-argumento ao fechamento de portas dos HCTPs. Do mesmo modo, o juiz de execução da $5^{\text {a } V E C ~ r e f o r c ̧ a ~ o ~ v a l o r ~ d o ~ p r o j e t o ~ i m p l e m e n t a d o ~ a ~ p a r t i r ~ d e ~ u m ~ c o n t e x t o ~}$ anterior, no qual os "doentes mentais" ficavam em unidades penitenciárias "espalhadas pelo estado inteiro" (Barros, 2018:77). Tanto num quanto no outro caso, temos um estado de coisas precedente que sofreu intervenção com o intuito de ser melhorado, aperfeiçoado. Entendo, assim, que as boas intenções não se dão dissociadas de uma temporalidade cujo passado inaceitável ou aviltante é o próprio elemento fundamentador do que se opera no presente. Esse ponto é de particular relevância pois, como veremos adiante, pautar o abolicionismo penal era frequentemente entendido como futuro irrealizável, o que também colocava o desafio tanto de conceituá-lo com nossos interlocutores de maneira "presentificada" quanto de defender que um presente "menos pior" não significa que o problema deixe de existir.

A fim de adentrar mais profundamente nos meandros entre humanitarismo e política que se apresentam nesses casos, acredito que Didier Fassin (2005) abre um rentável percurso reflexivo em seu diálogo com o pensamento de Giorgio Agamben. Fassin toma como ponto de partida a distinção entre "zoe"- vida nua- e "bios" - vida social - do filósofo italiano, para quem que os refugiados seriam a população governada justamente pela redução de sua existência tão somente como vida física. O exercício de poder, para ele, consiste em incidir sobre determinados humanos de modo a relegá-los à margem da lei. O campo de concentração, nesse sentido, seria o paradigma político da exceção, alhures à política, onde aqueles ali confinados não existiriam para além da dimensão “zoe”, isto é, da vida puramente físico-biológica, despida de sua faceta política.

Em contraponto, Fassin desenvolve o argumento, tomando como base seu estudo de políticas migratórias na França, de que a relação entre humanitarismo e política se dá menos por oposição do que pela mescla entre eles. Seu estudo etnográfico sobre a política migratória francesa da década de 1990 mostra como a solicitação de refúgio motivada por violência política perde espaço frente a um novo humanitarismo enraizado no que ele denomina "biolegitimidade" (Fassin, 2005:17). Corpos em sofrimento físico ou psíquico que comprovassem a falta de possibilidades terapêuticas em seus países de origem 
logravam a permissão de residência em solo francês, colocando em evidência um critério médico prevalente diante do qual o solicitante de refúgio é obrigado a "usar sua biologia em vez de sua biografia como um recurso para ganhar o direito de existir"(ibid:16).

Ao mesmo tempo que o paradigma biomédico ganha ascendência, motivações políticas de asilo são vistas com suspeição, num contexto em que a lógica securitária de fronteiras nacionais enquadra o solicitante de refúgio como ameaça. Outras motivações que não biomédicas ganham reconhecimento tão somente a partir de eventos episódicos, nomeadamente desastres ou crises humanitárias, os quais mobilizam a "compaixão" de Estados, momentos pontuais em que o estigma da ameaça cede ao da vítima. Para Fassin, tais momentos de expressão de generosidade seletiva obliteram o ordinário de repressão com que os solicitantes de refúgio são tratados, despontando "como momentos privilegiados de redenção coletiva". Essa oscilação entre compaixão e repressão é a base de seu argumento para sustentar que o político tem englobado cada vez mais o humanitário na biopolítica das democracias ocidentais, ao contrário da oposição defendida por Agamben, uma vez que "repressão e compaixão estão profundamente conectadas" (ibid:23).

Acredito que a intersecção entre repressão e compaixão é um prisma importante de inteligibilidade das situações aqui narradas. $\mathrm{O}$ agente de segurança que conduzia o veículo descreveu sua função no HCTP evocando a noção de "vida real" de modo a situar seu papel no sentido de mimetizar uma realidade bruta extramuros. "Nossa função é falar "não"”, nesse sentido, suscita um sentido humanitário, inferido também por sua afirmativa de que no HCTP a "área humana é maior", cujo propósito é quase o que se poderia descrever como uma pedagogia da negação.

Esse diálogo também colocou em evidência uma oposição que frequentemente perpassou nossas interlocuções com o corpo funcional dos HCTPs e que constantemente desafiava nossa posição ali dentro. Como dito pela enfermeira que pontuou nossa periodicidade de visita e adjetivou o trabalho como "bonito", a motivação de fechamento dos HCTPs não condizia com o que se passa na "vida real". Mais do que isso, tal motivação era também caracterizada como um desconhecimento do trabalho realizado pelo corpo funcional, tal como dissera outra enfermeira em determinado momento de uma visita: "as pessoas que chegam aqui não têm noção do trabalho. Falam que aqui é depósito de gente". 
Se víamos a lógica de cuidado ou humanitária como perniciosa, uma vez que ela baliza não só a atuação de funcionários, mas a própria existência das alas psiquiátricas e dos HCTPs, a nossa presença enquanto PCr não deixava de ser compreendida nesses termos. Justificar o tom do Relatório Hospitais-Prisão e explicar a importância de fechamento de portas de manicômios judiciários na interlocução com diretoria e corpo funcional esbarrava, não raro, no contra-argumento de que desprover a população em medida de segurança do cuidado não era acabar, senão instaurar uma violência, pois teriam que enfrentar a "vida real" ou a "rua" sozinhos(as).

No próximo tópico, procurarei adentrar mais detidamente na "economia moral" (Fassin, 2005) com que nos defrontamos, colocando-a em interface com os imperativos morais por nós mobilizados na tentativa de não somente defender a linha penal abolicionista, como também de legitimar nossa atuação de "assistência humanitária e religiosa" (Relatório Tortura, 2018:23), que nos garantia o acesso aos HCTPs enquanto PCr.

\section{Embate entre morais?}

Acordamos cedo naquela manhã de quinta-feira. Diferentemente das outras semanas, estaríamos percorrendo uma distância muito maior, pois visitaríamos o HCTP de Taubaté, manicômio judiciário integralmente masculino e localizado na região norte do Estado de São Paulo. O tempo era um fator crucial a ser respeitado, não somente pelo fato de que devíamos estar na porta do HCTP às 9h00 a fim de conseguir percorrer a maior parte possível de suas instalações antes do anoitecer, mas também porque era dia de rodízio do carro que usaríamos para a viagem. O veículo, pertencente a uma das membras do GT, deveria estar fora da zona de rodízio antes das 7 h00.

Apesar de nossos atrasos costumeiros para chegar ao ponto de encontro e de uma ligeira, porém crescente ansiedade, conseguimos vencer esse primeiro obstáculo temporal e cair na estrada antes do horário fatídico. Especulações sobre o que encontraríamos na visita eram a pauta do assunto que nos guiou durante o trajeto e, tal como planejávamos, por volta das nove horas estávamos defronte às duas grandes portas de madeira da entrada principal do HCTP de Taubaté. Encravadas numa longa parede branca onde se enfileiram grandes janelas gradeadas, foi no seu sopé, logo antes de entrar, que nos encontramos com o coordenador local da PCr: um padre. Ele realizava visitas ao HCTP com periodicidade semanal, sendo já conhecido tanto pelo diretor da unidade, quanto pelos 
seus funcionários. Não o conhecíamos até então devido ao nosso distanciamento com a equipe da PCr de Taubaté, com a qual tínhamos poucas oportunidades de encontro. Nesse dia, havia somente ele como representante de sua equipe.

De uma das grandes portas de madeira, as quais me lembravam portas medievais, sobretudo por suas longas dobradiças de metal adornadas, se desenhava o contorno de uma porta menor; uma porta que emoldura outra em seu centro, que se abriu para nós quando nos anunciamos como PCr. Dali para frente, passamos pelo protocolo que já conhecíamos muito bem: primeiramente apresentávamos a carteirinha da SAP com nossos documentos de identidade para os funcionários da portaria e, em seguida, passávamos nossos corpos e pertences por detectores de metais. Uma vez terminada essa primeira revista, como esperado, seguimos para a sala do diretor do HCTP, acompanhados do chefe de disciplina.

É importante ressaltar que nossas visitas nunca acontecem sem anúncio prévio de uma semana. Até a implementação das carteirinhas, enviávamos os nomes dos agentes pastorais por ofício, acompanhados de R.G. Em Taubaté, devido ao fato de que nossa presença era bem menos constante, além de estarmos com nossas carteirinhas, enviamos o costumeiro ofício endereçado ao diretor. Tal encaminhamento nunca se deu diretamente, uma vez que a incumbência dessa intermediação era do coordenador estadual da PCr.

Da portaria, seguimos para o interior do primeiro prédio, defronte o qual, em meio ao pátio que separava a portaria desse edifício, se localizava uma pequena capela. Logo próximo à entrada, estava a sala do diretor, que exalava ares arquitetônicos de um tribunal. Extremamente ampla e com paredes revestidas com um painel de madeira até a metade de um pé direito alto, a sensação era de um aspecto, ao mesmo tempo, antiquado e autoritário. A majestade da sala é reforçada por três símbolos, também feitos de madeira, fixados atrás da poltrona de couro do diretor, esta localizada na cabeceira de uma grande e envernizada mesa de reunião, onde nos sentamos após seu decoroso convite. Elevandose acima da poltrona, no centro da parede, está o crucifixo católico, avizinhado à direita pelo brasão da República Federativa do Brasil e à esquerda pelo brasão do Estado de São Paulo. Na parede diametralmente oposta a essa, está fixada uma lousa com os seguintes dizeres em cursiva: "Deus abençoe e guarde esta casa”. Na sequência, uma segunda frase, logo abaixo e no mesmo estilo, alertava: "É impossível para um homem aprender 
aquilo que já sabe”. Imediatamente, a leitura dessas curiosas palavras remeteu-me a um dos HCTPs de Franco da Rocha, onde, na antessala da diretoria, também constava no quadro de avisos uma frase de natureza religiosa, como descrito no capítulo anterior.

Na sequência das amenidades que protocolam as saudações iniciais, começamos a conversa falando sobre um de seus pacientes-detentos mais famosos. $\mathrm{O}$ furor em torno da questão residia no fato de que, naquele ano, completaria trinta anos de sua custódia, prazo máximo estabelecido pela legislação brasileira que um indivíduo pode permanecer privado de liberdade. Por ter ganhado notoriedade devido aos seus crimes cometidos na década de sessenta e setenta do século passado, o diretor relatou estar recebendo ligações de produtores midiáticos e jornalistas, interessados em produzir uma matéria sobre sua soltura.

O curioso, no entanto, é que nem mesmo o diretor sabia nos detalhar com precisão sua situação jurídica quando o interpelamos a respeito. $\mathrm{O}$ referido paciente-detento, segundo o que nos contou, já tivera sua periculosidade considerada cessada pelo perito psiquiatra, porém permanecia em custódia sob a prerrogativa de sua interdição civil. Este é um mecanismo jurídico que destitui o indivíduo do exercício de atos da vida civil, por ser o indivíduo considerado incapaz, e dotado de um curador que atua em seu nome. Mas por ser um dispositivo do Direito Civil, tal mecanismo não deveria incidir sobre o processo penal, uma vez que se trata de duas esferas normativas juridicamente distintas. Apesar de raro, não era o primeiro caso que ouvíamos a respeito dessa arbitrariedade, a qual, segundo o diretor, se devia ao fato de que nenhum juiz ousava assinar sua soltura, com receio da reincidência dos crimes. Sabia somente que o juiz civil responsável por esse caso deveria ser notificado sobre qualquer novidade do andamento de seu processo. "Ele está preso pelo estigma", asseverou o diretor.

Discorrendo mais detidamente sobre o histórico do caso, o diretor enfatizou as implicações políticas da desinternação de "pacientes de alta periculosidade". Explicou que, da mesma forma que um pai deve dizer "não" ao filho, em nome de seu próprio bemestar, suas decisões devem igualmente se pautar pelo zelo daqueles sob sua responsabilidade, ainda que pareçam rigorosas. Embora tivesse dito que sua periculosidade estava cessada, afirmou que seu "Transtorno de Personalidade Antisocial" poderia voltar a se repetir, custando a vida de outras vítimas. Haviam sido feitas 
tentativas de encaminhamento para residências terapêuticas, mas cada vez que se tomava contato com seu histórico criminal, sua vaga era imediatamente recusada.

Algo não muito diferente foi dito a respeito de outro "paciente" também considerado de "alta periculosidade". Seu caso foi trazido à tona porque também era alguém que chegava perto de seus trinta anos de internação. Embora também detivesse um histórico de crimes hediondos, a descrição da qual o diretor se valeu não se limitava aos atos passados, mas se referia também ao cotidiano de sua vivência no HCTP.

Utilizando "personificação do mal" como primeiras palavras para apresentá-lo, o diretor fez uma breve menção ao porquê de ter sido absolvido impropriamente e relatou que ele era alguém particularmente inteligente na interlocução com funcionários, agentes religiosos ou defensores públicos a fim de persuadi-los com suas histórias. Além disso, era comum que extorquisse "pacientes" considerados "mais cronificados", isto é, que apresentassem quadro físico ou psíquico mais agudos e, por isso, tornavam-se "vítimas" fáceis de seu perfil ardiloso. Segundo o diretor, seu comportamento é atribuído a um grave transtorno de personalidade, manifesto por suas "múltiplas personas", cada qual com uma "história" de vida particular.

Sua descrição patologizante lembrou-me a de outro paciente-detento com o qual o GT tomara contato em Franco da Rocha nos dois HCTPs. Nosso período de visitas coincidiu com sua custódia no HCTP I e, posteriormente, sua transferência para o II. Quando não o víamos pessoalmente, dificilmente seu nome não era mencionado por algum membro do corpo funcional, tal como a diretora do HCTP II, quando nos disse, em certa visita, que ele sempre conseguia o que queria, provocando conflitos e intrigas entre "pacientes" sem nunca se envolver diretamente e sem deixar provas para castigá-lo. Segundo ela, sua "inteligência" para artimanhas era resultado de um "crônico" transtorno de personalidade, o qual era incurável.

O alerta a pacientes-detentos(as) que inventam "histórias" para fins ardilosos era, ele próprio, uma história com a qual, enquanto GT, já estávamos acostumados e os canais entre prisões e manicômios judiciários eram comumente um substrato para seu enredo. $\mathrm{O}$ trânsito entre as alas psiquiátricas de unidades prisionais e os HCTPs é um fato que frequentemente despertava apreensões de várias ordens. Em uma certa visita a um dos HCTPs de Franco da Rocha, para os quais esse fluxo é mais intenso devido à proximidade geográfica com a PIII e o CDP Feminino - unidades que operam alas psiquiátricas - o 
chefe de enfermagem fez uma relação da rebelião de 2016 com a entrada progressiva no HCTP, em suas palavras, de um "perfil prisional".

Isso porque o pavilhão destruído pela rebelião era o maior da unidade e estava setorizado de acordo com o "perfil de pacientes", sendo o setor dos "dependentes químicos" o mais delicado, segundo ele. Em sua opinião particular, ele considerava a divisão espacial por grupos de categoria no HCTP um equívoco pois agrupava pessoas mais "malandras" e "astutas" com uma trajetória extensa em prisões, favorecendo seu fortalecimento para fins escusos. Em contato com o que seriam "os pacientes realmente psiquiátricos, mais rebaixados e cronificados" (ênfase oral do locutor), eles os manipulavam e os extorquiam aproveitando de suas vulnerabilidades. Talvez ele concordasse com a opinião do diretor de Taubaté no que concerne aos equívocos da máquina judiciária. Para ele, era inadequado alocar "dependentes químicos” em HCTPs, tendo como uma das consequências a rebelião de 2016, a qual, a seu ver, foi arquitetada justamente por indivíduos dessa categoria ${ }^{41}$.

É interessante notar, contudo, que a "astúcia" caracteriza, quase que exclusivamente, a população em medida de segurança procedente de alas psiquiátricas masculinas. As mulheres que vêm transferidas das alas psiquiátricas do CDP Feminino de Franco da Rocha raramente recebem esses adjetivos, a despeito de sua trajetória prisional. As referências a elas feitas passam por palavras como "instável", "rebaixada" ou "é uma novela" como ouvimos do diretor a respeito de Daiana, uma das "que dá mais trabalho".

$\mathrm{Na}$ prática, no entanto, esses marcadores não eram tão estanques, permitindo algumas transações entre eles. Um exemplo notório é a fala do mesmo chefe de enfermagem em outra ocasião, para quem "os dependentes químicos" não deviam ser custodiados em HCTPs, quando discorria sobre o "perfil prisional" que adentrava os manicômios judiciários. Dirigindo-se a mim e aos meus colegas de GT, quando acabáramos de sair da sala do diretor para começar a visita, explicou-nos que aqueles vindos da PIII “acabam virando pacientes psiquiátricos" pois se valem de psicotrópicos ${ }^{42}$

${ }^{41}$ A questão da chamada "dependência química" nos HCTPs extrapola o fôlego desta dissertação, podendo constituir um tema de pesquisa à parte devido à sua complexidade. Para maior aprofundamento, ver Relatório Hospitais-Prisão, p.49-50.

${ }^{42}$ A respeito da utilização de psicotrópicos como tecnologia de gestão do sistema prisional, ver Mallart (2016). Acesso em: https://diplomatique.org.br/as-pilulas-e-a-prisao-producao-e-gestao-dosofrimento/ 
para "aguentar" o HCTP, como, por exemplo, ansiolíticos para dormir. Resumiu a questão dizendo que "remédio puxa remédio", fazendo com que os psiquiatras os considerem “pacientes" tanto quanto "os outros". Além disso, os procedentes das alas psiquiátricas de presídios ocupavam oportunidades de serviços de manutenção e limpeza que garantem alguma renda, em detrimento dos "psiquiátricos", uma vez que são mais ágeis e competentes; "fazem o trabalho em dez minutos", disse. A seu ver, não somente esse fato seria prejudicial por privar "os psiquiátricos" de alguma renda, mas igualmente por potencialmente prejudicar um laudo psiquiátrico favorável, uma vez que exercer um trabalho na instituição, qualquer que seja, incide positivamente na recuperação. "Eles [os psiquiátricos] têm outro ritmo". Essa diferenciação pela utilização da palavra "ritmo" não era inédita. Já a tinha ouvido de Claudio, um paciente-detento sobre quem falarei mais adiante. Quando o interpelei sobre o tempo que havia passado na prisão antes de parar no manicômio judiciário e como comparava os dois espaços, respondeu-me: “aqui tem outro ritmo, prefiro o CDP”.

Da parte dos(as) pacientes-detentos(as) os "perfis" também eram marcadores de divisão entre eles(as) e não algo exclusivo à linguagem de funcionários. Certa feita, uma colega do GT conversava com cinco pacientes-detentos que haviam sido alocados em outro setor do HCTP I, conhecido como "Normativa I". Nesse espaço masculino, até a rebelião de 2016 que destruiu e desativou o pavilhão vizinho a ele, eram alocados unicamente indivíduos considerados "cronificados", vocabulário usado pelo corpo funcional para designar pessoas muito fragilizadas, física ou mentalmente. Aqueles que não foram provisoriamente transferidos para a PIII quando da destruição do pavilhão central, foram transferidos para a Normativa I, o que produziu algumas tensões devido à mescla de "perfis". Após aquela visita, nossa colega que conversava com os cinco rapazes nos contou que estavam extremamente insatisfeitos de estarem junto com "noias" e "loucos", como disseram, pois eles não o eram.

A conversa ia ficando longa e receava que não tivéssemos tempo o suficiente para visitar antes que o horário noturno de rodízio começasse. Depois de o diretor tecer algumas considerações sobre o "paciente" ardiloso, alertando-nos em tom sóbrio para suas "invenções" caso conversássemos com ele durante a visita, perguntamos sobre pessoas que, assim como o primeiro caso arbitrariamente mantido sob custódia, estariam internadas ali sem medida de segurança, isto é, com periculosidade cessada. Sua resposta nos mostrou pistas interessantes sobre o funcionamento do judiciário, que desafiavam o 
entendimento desse sistema sob o prisma da coerência e de detentor do conhecimento das instituições por onde a população em medida de segurança circula.

Àquele momento, como começou dizendo, o HCTP sob sua direção contava com seis pacientes-detentos, além do primeiro relatado, custodiados com a justificativa de “internação provisória”. Explicou-nos, então, que não era raro a ocorrência do que chamou de "surtos nervosos" em CDPs ou penitenciárias por parte de apenados ou pessoas aguardando julgamento e que tais ocorrências, por ordem judicial, poderiam ocasionar a transferência dessas pessoas para HCTPs, a fim de que passassem por uma avaliação psiquiátrica.

A dinâmica, portanto, operaria da seguinte maneira: uma vez encaminhado a um determinado HCTP devido a um "surto", a pessoa procedente de uma unidade penitenciária passaria por uma avaliação psiquiátrica e, a depender do resultado, sua alocação, bem como os trâmites de seu processo, poderiam ser alterados. Caso a avaliação não acusasse transtorno ou disfunção mental, o indivíduo retornaria à sua unidade penitenciária de origem. Caso contrário, ele seria retido no HCTP por tempo julgado necessário e, conforme a evolução de seu quadro, poderia ter sua pena convertida em medida de segurança.

Em sua opinião como diretor, tais encaminhamentos eram fruto de um desconhecimento da magistratura a respeito da função dos HCTPs. Simplesmente por conterem a palavra "Hospital” em seu nome, os juízes entenderiam que, como instituições de saúde parte do sistema carcerário, os Hospitais de Custódia e Tratamento Psiquiátrico deveriam estar aptos a acolher, temporariamente, aqueles(as) provenientes de penitenciárias e CDPs em "surto". O equívoco, segundo o diretor, estaria no fato de que na maioria das vezes essas ocorrências não seriam "psíquicas", senão "clínicas", justificando encaminhamento mais adequado ao tratamento ambulatorial do que hospitalar. Nessa distinção entre psíquico e clínico, o diretor reforçou sua profissão de psicólogo em contraste com os saberes da magistratura, não afinados a essas nuances. A falta de comunicação entre juízes e demais agentes do sistema carcerário seria uma das principais causas do que chamou de "desorganização do fluxo de pacientes", uma vez que um sério agravante desses encaminhamentos à toque de caixa era o desrespeito à sequência da fila de espera para os HCTPs, a qual, à época, compreendia um período de 
dois anos, em média, de espera. Esses encaminhamentos arbitrários, portanto, ocupariam a vaga de outros que poderiam estar aguardando há muito tempo.

A assertiva de "desorganização" parece abrir uma fresta na sobreposição entre medicina e direito penal no século XIX, tão bem analisada por Foucault (2001). O filósofo francês é certeiro ao demonstrar como a aliança dessas ciências esteve a serviço da produção de saberes que deslocava o foco de atos considerados criminosos para a construção do sujeito criminoso e seu potencial delitivo. A imbricação entre saber e poder é chave para seu argumento da produção de saberes normalizadores que classificam comportamentos a fim de construir a figura do "anormal", este antes regido pela impulsividade monstruosa do que pela razão. Embora seus aportes nos sejam rentáveis para entender como os pacientes-detentos sobre quem conversávamos são referidos, gostaria de ajustar o foco para a fissura que parece ter sido aberta na conjunção dessas searas pela percepção do diretor a respeito do fluxo dos "pacientes". O desconhecimento, e não propriamente o saber, ganha relevo para orientar essa dinâmica.

Nem sempre, entretanto, a referência ao judiciário se dá por esse viés. Depois de conversar com Daiana em uma das visitas à ala feminina, avistei uma senhora cujo rosto me era familiar. Aproximei-me de Lúcia para perguntar o que tinha acontecido pois ela era uma paciente-detenta que já havia conseguido desinternação e não deveria estar mais ali. Respondeu-me que não tinha assinado "a carteirinha no fórum" 43 e essa falta a havia feito regredir ao manicômio judiciário. Conversando com uma agente de disciplina de outro HCTP sobre esse caso, ela afirmou que a situação era um fato comum e diante de minha indignação, retorquiu: "ué, assinar a carteirinha é parte do tratamento". Sua fala apontou para uma fusão de áreas do saber, em que um ato burocrático do Direito é compreendido como um tratamento médico, o que infere uma legitimação para o retorno ao HCTP. Lúcia, na prática, deveria passar novamente por exames de cessação de periculosidade, dentro de um manicômio judiciário, porque seu nome não havia sido escrito no Fórum Criminal na periodicidade exigida.

A naturalidade com que a agente de disciplina me explicou a regressão de Lúcia chamou-me a atenção também porque ela se definia como opositiva à atual gestão do

\footnotetext{
${ }^{43} \mathrm{O}$ ato de "assinar a carteirinha" refere-se a uma liberdade condicional, em que o(a) egresso(a) do sistema penitenciário tem direito à liberdade mediante assinatura periódica em Vara Criminal designada. O desrespeito a essa periodicidade, por motivos injustificados, acarreta na regressão de regime.
} 
HCTP. Pouco antes de comentar-lhe a respeito do caso de Lúcia, a agente me contava sobre uma outra época do HCTP, a qual definiu como "anos dourados". Antes havia mais festas, abertas à vizinhança do HCTP, e excursões dos(as) "pacientes" ao centro da cidade de Franco da Rocha, com o objetivo de integrá-los à “comunidade", segundo me contou. Era um período "mais humanizado", em seus dizeres, e sentia censuras da atual direção, bem como de outros funcionários, por ser "muito dos Direitos Humanos". Não havia contradição, para ela, entre sua visão a respeito do retorno de Lúcia pela sua não assinatura e sua identificação "humanitária".

Não menos intrigante que a concepção da agente de disciplina foi a continuação da fala do diretor a respeito do fluxo de "pacientes". Mais especificamente, foi curioso ouvir sua postura institucional diante da "desorganização". Isso porque, em casos como esse, é costumeiro que alegue ao judiciário que o "paciente" encaminhado tem um quadro psíquico delicado, como maneira de "ajudá-lo". A razão para tal é que, ao retê-lo com base no argumento de saúde mental, evitaria seu retorno às condições "desumanas", típica dos presídios brasileiros, alocando-o no HCTP, o qual, a seu ver, é mais salubre e não trabalha em regime de superlotação. Ali, em suas palavras, seria um local "melhor".

Após essa longa conversa, seguimos efetivamente para a visita das instalações, acompanhados do chefe de disciplina. Uma percepção que foi comum aos membros do GT quando do término da visita foi a dificuldade de encontrar momentos em que pudéssemos olhar e andar segundo nossa vontade. Nos HCTPs de Franco da Rocha, não obstante estarmos sempre acompanhados de um agente de disciplina ou de um chefe de enfermagem, havia intervalos de tempo em que a interlocução com os(as) pacientesdetentos(as) era mais respeitada em termos de privacidade. Já em Taubaté, por outro lado, o chefe de disciplina que nos guiava conduziu a visita de modo cuidadosamente controlado; era perceptível que as falas fortuitas com alguns funcionários ou mesmo com pacientes-detentos que cruzavam nosso caminho pelo longo corredor axial era relativamente contida. Além disso, sua condução assemelhava-se a uma espécie de "city tour" devido ao entusiasmo com que descrevia a instituição e as atividades dos "pacientes", impedindo que tivéssemos um afastamento de sua presença durante o percurso.

A primeira parada que faríamos seria a oficina de trabalho da Fundação de Amparo ao Preso (FUNAP). Cruzamos um pequeno espaço a céu aberto após sair do 
edifício onde se encontrava a sala do diretor, espaço esse que divisava o prédio onde estávamos de um imponente pavilhão, a apenas alguns metros de distância daquele. Paramos defronte a um portão gradeado de ferro e, por entre suas frestas, era possível ver, a despeito da pouca luminosidade do interior em ofuscante contraste com o sol daquela manhã, outro longo corredor margeado por acessos gradeados à direita e à esquerda.

Enquanto aguardávamos a abertura do portão, o chefe de disciplina preencheu o intervalo em que um funcionário procurava a chave para contar um pouco sobre o passado da instituição. Começou contando-nos que antes de ser inaugurado como hospital psiquiátrico, em 1914, aquelas instalações faziam parte de um presídio rural. Sua voz em primeiro plano era engolfada pelo farfalhar de passos, voz e sons metálicos em eco vindos do interior do prédio. Esse confuso ressoar dava-se em camadas sonoras, entre as quais aquelas mais longínquas e ecoantes ajudavam-nos a ter uma percepção da longa extensão do corredor, antes mesmo que se pudesse vê-lo de fato. Fazendo referência ao pavilhão por qual passamos na entrada, o chefe de disciplina disse que esse espaço era coletivo até 1961, quando houve uma grande rebelião na qual se queimaram colchões. A ordem do diretor, à época, foi de trancar os portões a fim de que se evitasse a fuga, medida essa que foi responsável pela carbonização da maioria que estava presa. A parir de então, foram construídas celas individuais.

Concomitante ao ouvir de seu relato, meu olhar passeava pela arquitetura da fachada até estacionar em outra frase pousada no batente superior do portão de ferro que barrava nossa entrada e aumentava nossa ansiedade: "Toda instituição é um meio pelo qual os indivíduos podem se enriquecer ou empobrecer e se esvaziar como seres humanos. Assim como todo o indivíduo pode enriquecer ou empobrecer a instituição onde está inserido”.

Essa nova recorrência de frases curiosas em determinados locais do complexo disparou a lembrança de outra que me chamara a atenção em um dos manicômios judiciários de Franco da Rocha. Nossa visita coincidiu com o dia da mulher e na pequena ala feminina era possível ler em sua parede externa, defronte para um pequeno jardim limitado pelo perímetro gradeado que delimita o entorno da ala, a seguinte frase escrita em grande cartaz: "Porque cada dia representa uma página do livro da sua vida. Faça com que cada uma se torne memorável!! Parabéns a todas as mulheres deste HCTP”. Do teto da pequena varanda, da qual a parede fazia parte, pendiam papeis crepons 
coloridos em espiral. Grandes flores de cartolina vermelha salpicavam a parede em questão, emoldurando o cartaz em seu centro. Logo abaixo, encontrava-se colada uma imagem da personagem Mulher Maravilha.

Enquanto refletia sobre a ocorrência de tais frases em diferentes instituições, meu pensamento foi interrompido pelo tilintar das chaves que finalmente abriam o portão.

Seguindo pelo corredor à esquerda, adentramos um amplo galpão onde se alocava uma grande diversidade de peças artesanais: desde mesas de madeira até brinquedos infantis ou mesmo alguns bordados, todos produzidos por pacientes-detentos. Serpenteamos vagarosamente pelo espaço enquanto nosso entusiasmado guia tecia alguns comentários elogiosos sobre os trabalhos e alguns poucos pacientes-detentos trabalhavam em suas obras. A primeira coisa que me chamou a atenção, entretanto, assim que visualizamos o espaço desde a porta da oficina foi outra frase em posição elevada, fixada na parede ao fundo: "Transforme as pedras que você tropeça nas pedras da sua escada."

Naquele momento, minha memória foi novamente acionada para uma visita em um dos HCTPs de Franco da Rocha, quando foi permitida nossa entrada na "DASPRE A Grife que Liberta", como se lia na placa logo acima da porta de entrada. Trata-se de uma oficina de artesanato administrada também pela FUNAP e cujas unidades estão presentes em várias penitenciárias paulistas, incluindo o HCTP em questão, como maneira de geração de renda à população encarcerada feminina ${ }^{44}$. Apesar de constar no website da fundação que são "presas" que realizam esse trabalho, encontramos, naquela visita, alguns poucos homens confeccionando roupas ou bordados juntamente com as mulheres. Foi ali que conheci uma agente de segurança da SAP que há 28 anos trabalha como professora de corte e costura nessa oficina. Muito comunicativa, contou-me que adquiriu a prática manual depois que perdeu seu filho. "A arte foi minha maneira de lidar com a dor", disse. Em tom orgulhoso, falou que sentia muito prazer de ensinar "as mulheres" trabalhos manuais e que, em todo esse tempo de dedicação a esse ofício, somente "uma paciente voltou", disse referindo-se à reincidência.

\footnotetext{
${ }^{44}$ Como vemos em uma de suas postagens de fim de ano: "O Natal está chegando. Se você quer dar presentes originais, de qualidade e, de quebra, ainda ter uma atitude de responsabilidade social, vale dar uma passada no Bazar de produtos da grife Daspre. Os produtos estão à venda até 19 de dezembro na loja "Do Lado de Lá", da FUNAP - órgão do Governo do Estado, vinculado à Secretaria da Administração Penitenciária, responsável pelo desenvolvimento de ações que contribuam para a recuperação de presos e ex-presidiários." Para mais informações, ver: http://www.saopaulo.sp.gov.br/ultimas-noticias/bazar-dagrife-daspre-vai-ate-19-de-dezembro/
} 
Na saída do Galpão da FUNAP, o entusiasmado chefe de disciplina abordou dois pacientes-detentos que haviam acabado de sair de uma sala não muito distante dali. Depois de brevemente nos apresentar como "a Pastoral", ele explicou que os "pacientes" vinham do que ele nos explicou como sendo uma terapia em grupo, na qual, semanalmente, aqueles que voluntariamente quisessem participar eram bem-vindos. " $\mathrm{O}$ falar sobre seus delitos", era o principal objetivo, segundo ele, dos encontros terapêuticos. Após sua explicação, incitado pelo chefe de disciplina a dar um breve depoimento, o mais baixo entre os dois rapazes vestido com um uniforme bege marcado com a sigla HCTP, em preto desbotado no centro de seu peito pontuou: "Aqui tenho trabalho, lazer e espiritualidade, coisa que lá fora não tive. (...) Acreditava que todos eram errados e agora percebo como sou culpado pelos meus atos." Ouvimos em silêncio suas palavras enquanto o outro a seu lado assentia com um movimento de cabeça, alternando seu olhar entre seu colega e nós. Com uma breve interrupção, o chefe de disciplina complementou sua fala nos dizendo que era uma iniciativa relativamente recente, que refletia uma mudança do corpo funcional do HCTP. Apesar de haver funcionários "remanescentes de outra época", alinhados com uma "educação mais punitiva", essa atividade mostrava um pouco dos "novos ares" da instituição.

À medida que prosseguíamos com a visita, percebia como as histórias que nos eram contadas, seja pelas palavras do nosso condutor ou pelas paredes do estabelecimento, conectavam-se com outras, de outros espaços. O "falar sobre seus delitos", como disse o chefe de disciplina de Taubaté, ecoa também uma preocupação recorrente de pacientes-detentos(as) dos HCTPs de Franco da Rocha e que nos é trazida como uma das principais demandas: o exame de cessação de periculosidade. Inúmeras foram as vezes que ouvi a pergunta: "Meu laudo está atrasado, o senhor pode ver para mim?"

Como um exame que é essencialmente uma entrevista feita por um médico psiquiatra, o que e como se fala é uma questão delicada para os(as) entrevistados(as), porquanto suas consequências podem determinar-lhes o destino por, no mínimo, um ano. Certa vez, conversando com Claudio, um paciente-detento custodiado no HCTP I de Franco da Rocha, fiquei sabendo um pouco mais do que se espera escutar em termos de conteúdo. "Joguei o jogo", disse ele, "tirei uma manilha da manga e disse que sentia mais falta de meu pai”. Essa foi a resposta que deu quando perguntado do que mais sentia saudades de sua época anterior ao manicômio judiciário. 
O mais interessante, porém, foi quando Claudio me contou a respeito do comentário feito pelo perito que o entrevistou quando as perguntas haviam sido todas respondidas. Segundo Claudio, o perito lhe dissera que, embora não pudesse dizer nada oficialmente pois somente o laudo redigido poderia fazê-lo, considerava-o apto para ser transferido para a "colônia", como é chamado o HCTP II de Franco da Rocha. Sendo uma unidade que opera qual um regime semi-aberto do sistema penitenciário, as pessoas nela custodiadas podem ter o direito, caso tenham respaldo familiar, de efetuar Visitas Domiciliares Assistidas (VDAs). As VDAs são períodos de tempo, reduzidos a princípio e estendidos posteriormente, para que pacientes-detentos(as) passem estadias com parentes ou alguém responsável a fim de que se adaptem progressivamente à vida póscustódia. Caso haja uma falta disciplinar cometida ou o desrespeito à data de retorno à "colônia", esse direito pode ser suspenso, ocasionando, em alguns casos mais graves, na regressão ao HCTP I, onde, assim como em Taubaté, a possibilidade de realizar VDAs é inexistente.

Contra as expectativas do perito, no entanto, Claudio disse que preferia ficar mais tempo custodiado no HCTP I a ser transferido para o II pois sabia que lá havia circulação de entorpecentes ilícitos entre os "pacientes" e não queria "cair em tentação" uma vez que fora parar no manicômio judiciário depois de várias "passagens pelo sistema por causa de drogas", como me disse ${ }^{45}$. Diante disso, de acordo com Claudio, o perito apenas lhe respondeu: "vou ver o que posso fazer por você". Uma vez tendo me contado o episódio e achando graça da minha expressão de surpresa, explicou-me que sabia o mais apropriado a ser dito para que conseguisse uma desinternação adiantada: "é como matemática, engenharia mesmo, sabe?" Ele estava convicto de que sua engenhosa resposta autocomplacente poderia ter lhe sido a chave que o levaria novamente ao "mundão", como descreveu o mundo extramuros, uma vez que a passagem pelo HCTP II, antes da desinternação completa, não é obrigatória ${ }^{46}$.

Os dois rapazes que ouvíamos acompanhados do chefe de disciplina talvez soubessem disso tão bem quanto Claudio. Depois de algumas outras palavras elogiosas, o chefe de disciplina ressaltou que nosso tempo era curto e que precisava dar continuidade

\footnotetext{
45 "Passagens pelo sistema" significa o fato de já ter sido condenado à prisão.

${ }^{46} \mathrm{O}$ caso de Claudio parece ser um forte contraponto a noção de "mortificação do eu" de Erving Goffman (2005), que pode ser expressa como o efeito produzido pelo confinamento em "instituições totais", no qual o "eu" dilui-se numa padronização sem qualquer possibilidade de agência.
} 
à visita. Despedimo-nos e seguimos para o pavilhão "Acácio Nogueira" 47 , ao fundo do longo corredor axial, também conhecido como "poleiro". Trata-se de uma longa construção estreita longitudinal com dois andares de celas, cada qual comportando duas pessoas. Devido à alta demanda, algumas delas comportavam três pessoas. Sem um piso dividindo os dois andares, logo ao cruzar o portão gradeado que lhe dá acesso, o olhar é impelido para cima, buscando o ápice de seu alto pé direito. O ambiente lembra um aspecto fabril, tanto por sua amplitude vertical quanto longitudinal. Parcialmente iluminado pela luz natural que penetra por espremidas janelas superiores, sua parte inferior é complementada pela luz artificial de longas lâmpadas suspensas por um eixo metálico que cruza todo o comprimento do corredor. Do perímetro do ambiente, vemos muitas celas enfileiradas, tanto no piso térreo quanto no superior. O telhado de cor terrosa é visto através de grandes vãos formados pelas passarelas suspensas que margeiam as numerosas celas do andar de cima.

Enquanto nosso olhar percorre o ambiente, vozes ecoadas e algumas risadas fazem a paisagem sonora. $\mathrm{O}$ forte odor de urina invade nossas narinas e se mescla ao já conhecido odor de tabaco, característico também dos HCTPs de Franco da Rocha. Uma das celas, não muito distante de nós, estava desocupada e com sua porta aberta, permitindo que víssemos seu interior. Relativamente pequenas, elas têm um espaço que acomoda duas camas de solteiro e uma privada acoplada ao chão verde musgo, que pode ser descrita como um desnível circular côncavo em que não há qualquer apoio para o corpo. As paredes tinham fios que improvisavam um varal e uma cortina e eram adornadas com recortes de revistas, jornais, fotos e alguns textos cujo conteúdo a distância não me permitia ler.

O chefe de disciplina nos explicou, então, que poderíamos circular pelo espaço livremente, podendo conversar com os "pacientes" através das pequenas aberturas

${ }^{47}$ Cada pavilhão tem um nome específico. Além desse, pude identificar, ao longo de nosso percurso, os pavilhões Herculano de Freitas e Toledo Piza. Em rápida pesquisa, identifiquei que Uladislau Herculano de Freitas Guimarães é considerado um grande jurista brasileiro da virada do século XIX para o século XX, tendo, em sua trajetória profissional, exercido cargos jurídicos, como Ministro do STF, e políticos, tanto no poder Executivo quanto Legislativo federal. Wladimir de Toledo Piza, por sua vez, foi bacharel em medicina, mas também se dedicou à carreira política no Estado de São Paulo, primeiramente dirigindo a pasta de saúde e, depois, como prefeito da Capital na década de 1950. Não encontrei, contudo, informações sobre Acácio Nogueira, mas os nomes de ruas que levam seu nome apresentam o título de "Dr.", o que também sugere uma atuação profissional ligada às ciências biomédicas ou jurídicas. Fontes: http://www.cartaforense.com.br/conteudo/colunas/herculano-de-freitas-politico-professor-e-ministro-do$\underline{\mathrm{stf} / 17743}$

$\underline{\text { http://www.fgv.br/CPDOC/BUSCA/dicionarios/verbete-biografico/piza-vladmir-de-toledo }}$ 
retangulares das portas opacas de metal, que podem ser descritas como semelhantes às que recebem cartas de correio. Naquele horário, eles acabavam de terminar o almoço, conhecido como "boia", uma pequena marmita distribuída através dessas aberturas duas vezes ao dia.

Espalhamo-nos, enquanto GT, com nossos caderninhos e canetas em mãos e, com um certo constrangimento, subi as escadas para o piso superior sem saber exatamente como começar uma conversa através das mini aberturas. Andei um pouco pela longa sucessão de portas fechadas, à esquerda e à direita, que convergia para a parede ao fundo até escolher aleatoriamente a terceira cela da esquerda para começar. Logo abaixo das plaquinhas com nomes, identificando os que ali se encontravam, dois olhos de tez levemente enrugada me miravam através do pequeno buraco. Apresentei-me como $\mathrm{PCr}$ dizendo meu nome, perguntando-lhe o seu em seguida. Estendi minha mão por entre o vão a fim de dar a Nathan um aperto de mão, encurvando minha coluna até que meus olhos ficassem no mesmo nível que os seus e indaguei-lhe se estava tudo bem. Respondeu que sim, não tinha nada a reclamar, a não ser que gostaria de ser inscrito no curso de português que era oferecido pela unidade, pois era analfabeto. Relatou que demandara sua inscrição há algum tempo, mas não obtivera nenhum retorno até então.

Prometi que levaria sua demanda ao chefe de disciplina que nos acompanhava para saber se havia algum problema. Pediu-me, então, que lhe lesse seu pequeno livreto católico, no qual havia algumas orações. Segundo ele, aquelas palavras ajudavam a espantar o "demônio" que sempre o atacava de surpresa. Sua fala era truncada, ao contrário da eloquência do paciente-detento que nos falava sobre a importância que o HCTP tinha em sua vida. Pensei que poderia ser o efeito dos psicotrópicos que já estávamos habituados de perceber durante nossas visitas: olhar vitrificado, fala balbuciada e extremidades corporais trêmulas. Um dos mais comuns a serem administrados e a causar tais efeitos era o recorrente haloperidol, cujo nome ouvíamos, em várias visitas, tanto de pacientes-detentos(as) quanto de funcionários.

Fiz como me pediu: li algumas passagens enquanto Nathan me ouvia em silêncio, sentindo, com o passar dos minutos, um maior desconforto devido à posição arqueada do meu corpo. Terminei com um Pai Nosso e uma Ave Maria, os quais rezamos em uníssono. Despedi-me dizendo que precisava continuar a visita e que não deixaria de perguntar a respeito do curso de português. Quando apertamos as mãos em despedida, para que não 
esquecesse, ele me passou um bilhetinho de papel rasgado com seu nome e sua matrícula escritos em caligrafia irregular e tremida.

\title{
Relatórios e bilhetinhos: o que se transmite através da escrita?
}

\author{
I do not revive the case of the Nazi Endloesung (final solution) \\ of the Jewish problem in order to condemn the Germans, or \\ make them look worse than other peoples, but to recall to our \\ attention dangers which lurk in our midst always \\ (Hughes, 1962:2).
}

A citação acima é do sociólogo estadunidense Everett C. Hughes, de seu famoso artigo "Good People and Dirty Work” (1962). Nele, o autor se debate com a questão de como alemães comuns e "civilizados" foram capazes de serem coniventes com o "trabalho sujo" do Holocausto, uma das maiores atrocidades humanas da história recente. Seu ponto de partida reflexivo é interessante de ser pontuado pois compartilha algumas de minhas preocupações com esses excertos etnográficos. Nesse sentido, a citação sintetiza a cautela com que realiza sua investigação, afastando-se de explicações simplistas com visitas a demonizar o povo alemão ou subscrever inteiramente um caso complexo ao "ódio racial” (ibid:4). Antes, ele procura indagar quais condições sociais, circunscritas a um determinado contexto, permitiram que um massacre de tamanhas proporções fosse coniventemente perpetrado. Isso abre espaço para que o problema, longe de ser algo particular à nacionalidade alemã, seja entendido como algo passível de ocorrência em outras sociedades.

Tomo emprestado, então, sua proposta investigativa a fim de apreender a complexidade do que Hughes nomeia de "a constituição moral e social da sociedade" (:11, tradução minha). Segundo seu raciocínio, a base para essa constituição se daria no modo como uma dada sociedade lida com seus grupos excluídos, seus "outros", seja de forma direta ou delegada, o que depende de uma "consciência" disposta ou não a saber o que se lhes passa. Conquanto procure, assim como o autor, também deslocar o enfoque de categorias simplistas de "ódio" ou "violência" e procure indagar sob quais condições a conivência ao que foi entendido, pelo GT, como violador dos HCTPs é possível, chamo a atenção para alguns limites de seu olhar analítico.

Embora o paralelo entre sistema carcerário brasileiro e referências de violências brutais seja comum, esse não é exatamente meu foco ao mobilizar o trabalho de Hughes. 
Com efeito, no prefácio do Relatório Tortura em Tempos de Encarceramento em Massa, intitulado "Ó Vós que Entrais" e, como dito, lançado pelo Escritório Nacional da PCr em dezembro de 2018, temos uma aproximação das prisões brasileiras com o inferno descrito na obra de Dante Alighieri ${ }^{48}$. Mais adiante no prefácio, dessa vez fazendo uma comparação aos campos de concentração nazistas, cita-se uma indagação retórica recorrente de Pe. Chico, sobre quem falamos no capítulo anterior: "É possível morrer em Auschwitz depois de Auschwitz?" (Relatório Tortura, 2018:19). Na sequência, o texto do prefácio continua:

Infelizmente, há sempre a mesma resposta: sim! Os nossos presídios são extensões do que aconteceu nos campos de concentração. As torturas e os maus tratos são as práticas corriqueiras das casas de punição e castigos, que chamamos de presídios. Enquanto houver presídios, cadeias, campos de torturas e de maus tratos, Auschwitz continuará sendo uma triste realidade (Ibid).

Minha contribuição à interessante pergunta seria de questionar se sua pertinência ainda é possível quando a autoevidência da violência inexiste. A diferença que demarco é que, tanto em Hughes como na interrogação de Pe. Chico, temos um pressuposto de uma violência cometida. Para o sociólogo estadunidense, essa inferência é cabível pois seu objetivo investigativo tem como premissa o cometimento de atrocidades. Não é, portanto, o atroz, que está em questão, mas como foi possível cometê-lo. Não muito diferente, a retórica de Pe. Chico e o parágrafo que parece servir de resposta sugerem a extensão temporal e espacial de um dos campos de concentração mais famosos, devido à magnitude da violência ali cometida, para os espaços carcerários brasileiros da atualidade.

Entretanto, acredito que nos excertos etnográficos aqui trazidos essa transposição não pode ser tão facilmente feita. Em primeiro lugar, Hughes em suas tentativas de entrevistar "boas pessoas" sobre o que se passara nos campos de concentração, percebia estratégias de evasão retórica, como lapsos de memória ou indisposição para pensar a respeito (Hughes, 1962:6). Por outro lado, enquanto GT, tínhamos um problema anterior a esse porquanto nossos interlocutores não mobilizavam a ideia de violência para qualificar suas ações. Ainda que também encontrássemos "boas pessoas”, para usar os termos do autor, essas não praticavam e tampouco eram coniventes com "trabalho sujo". Muito ao contrário, tratava-se de pessoas que se viam como "boas" e que, em suas

\footnotetext{
48 “Essa é a frase que Dante, na Divina Comédia, viu inscrita na Porta do Inferno. No inferno das prisões não existem placas, mas o condenado sabe que vai começar seu padecimento. Quando as grades se fecham, abre-se um mundo de violência, corrupção, superlotação, promiscuidade e descaso - muito descaso - por parte das autoridades públicas, famílias e sociedade" (Relatório Tortura, 2018:13).
} 
percepções particulares, faziam "bons trabalhos". A evitação ao tema ou os lapsos de memória com os quais Hughes teve de lidar não eram, em absoluto, presentes no caso dos HCTPs. Ao contrário, o que se nos apresentava era um certo tom de orgulho, tal como vimos com a agente de segurança que atribuía ao artesanato por ela ensinado um papel importante tanto na forma de lidar com a própria dor da perda de seu filho, quanto no seu valor terapêutico para as(os) "pacientes".

No que concerne ao fato de ressignificar Auschwitz como metáfora para as unidades penitenciárias, talvez os(as) próprios(as) funcionários(as) dos manicômios judiciários concordassem com essa comparação. Como expresso pelo diretor do HCTP de Taubaté, sua atitude de "ajuda" aos provenientes de penitenciárias era ela mesma fundamentada num imperativo moral que sustenta uma responsabilidade pelo destino de outrem, qual um pai, a fim de evitar o retorno a um lugar que se sabe ser degradante. Aparentemente, a falsa alegação de um "quadro psíquico", a despeito da ausência de qualquer anteparo legal, ganha contornos de uma "biolegitimidade", para recuperar Fassin (2005), que, se não prescinde da lei para sua validade, dá-lhe inteligibilidade justamente pela intersecção do moral com o legal, refletindo a intrincada imbricação entre humanitário e político, de que nos fala o antropólogo francês.

A "casa", avizinhada por uma capela, e sobre a qual the recai os pedidos da curiosa frase de sua opulente sala, demandando a "Deus" proteção e guarda, parece ser uma espécie de lar cujos habitantes, a fim de "aprender", devem se despir da arrogância do que acham que "sabem", podendo "enriquecer-se" ou "empobrecer-se" "como seres humanos”, como se dispusessem de um arbítrio disponível até para aqueles que "personificam o mal". Nessa "economia moral", o zelo do pai e seu ensino regido pelo dever de "dizer não" buscam auxiliar em transformar as pedras de tropeço nos degraus da escada de cada um, cada qual com seu "ritmo" de subida. Seja confeccionando artesanatos, seja trabalhando na manutenção ou limpeza, a dedicação aliada ao não "dar trabalho" e tampouco ser "uma novela", parecem ser a chave dessa ascensão. Como nos foi dito, ter "trabalho, lazer e espiritualidade" constrói o caminho cujo destino já está anunciado no próprio nome da empresa: "DASPRE - A grife que liberta". Essa moralidade emanante de enunciados escritos vai ao encontro do que Foucault (1987) discorre sobre a lógica reformista inglesa da prisão, para a qual o trabalho realizado pelo sujeito apenado tem um valor fundamentalmente espiritual. Cito: 
A prisão se pareceria demais com uma fábrica deixando-se os detentos trabalhar em comum. As razões positivas em seguida: o isolamento constitui 'um choque terrível', a partir do qual o condenado, escapando às más influências, pode fazer meia-volta e redescobrir no fundo de sua consciência o bem; o trabalho solitário se tornará então tanto um exercício de conversão quanto de aprendizado; não reformará simplesmente o jogo de interesses próprios ao homo economicus, mas também os imperativos do indivíduo moral. (Foucault, 1987:101).

É nessa "casa" de muito labor que, enquanto se retém alguns filhos em nome de seu próprio bem, trabalhando por sua salvação, orgulha-se também da saída de filhas que não mais retornam porque fizeram um bom trabalho; porque mereceram sua liberdade. Em tanto tempo, apenas uma havia regressado para juntar-se novamente às demais a fim de trabalhar, cada dia, numa "página do livro de sua vida". A resiliência cotidiana seria a fonte do poder que eventualmente lhes permitiria, heroicamente, "salvar o dia" de sua libertação, tal como a Mulher Maravilha.

Entendo que falar dessa "casa de cada dia" é falar do "Estado de cada dia", em suas práticas cotidianas entre as quais a escrita ocupa um lugar central, uma vez que, como bem salientam Veena Das e Deborah Poole, "a maior parte do estado moderno está construído a partir de práticas de escrita" (Das e Poole, 2004:25), escrita essa que não meramente reflete, mas toma o gênero como marcador constitutivo. Os cartazes e frases espalhados pelos HCTPs, assim como os documentos, são pertencentes a um plano cotidiano de fazimento do Estado, de uma "trama de sentidos" (Vianna e Lowenkron, 2017:n.p.) a qual não se faz apartada de mobilizações afetivas, inscrevendo imperativos morais generificados que fazem da "casa" o lócus primordial dos degraus a serem escalados. Com efeito, Adriana Vianna e Laura Lowenkron demarcam a importância de uma abordagem analítica que não prescinda desse olhar:

E, onde há o cuidado e a vigilância em não tomar o Estado como unidade institucional, ideológica ou ideacional, isso em geral não se faz ao ponto de considerar que seus processos permanentes de constituição são sempre e necessariamente sexualizados, generificados e atravessados por afetos. Defendemos, assim, que levar a sério a complexidade e a processualidade inerentes ao Estado, implica compreendê-lo como trama de sentidos, possibilidades de ação e formas de interdição feitas de e por dinâmicas de gênero (Vianna e Lowenkron, 2017: n.p.) ${ }^{49}$

Cabe questionar, contudo, em direção a que tipo de liberdade se está caminhando. Quando relembramos a conversa sobre seu "paciente" famoso, por exemplo, vemos que

49 Destaco a etnografia de Veena Das (2007) na qual a autora tece, no que diz respeito às imbricações entre Estado e gênero, uma potente análise mostrando como a inscrição da violência no corpo das mulheres durante o evento da Partição da Índia é um evento fundante do próprio Estado indiano. 
sua periculosidade está cessada, o que, ao rigor da lei, deveria dar-lhe o direito da desinternação. Entretanto, o limbo moral-jurídico no qual se encontra, fundado no temor da reincidência de seus crimes, parece ser a principal pedra interposta em seu caminho ante a qual toda e qualquer tentativa de sua parte para transformá-la em degrau resulta ineficiente ao esbarrar na arbitrariedade do judiciário aliada à conivência da diretoria do HCTP, que se resguarda na alegação do não entendimento de seu caso. Aqui fica patente a "sobreposição", e não "justaposição" do "modelo jurídico-punitivo" sobre o "psiquiátrico terapêutico" (Carrara, 2010:19). O primeiro exerce uma barreira para o segundo, a despeito da avaliação médica que lhe atesta a cessação de periculosidade.

Não é somente, portanto, o judiciário único agente coordenador desses "fluxos", pois a "casa” é, tanto quanto, um ator que os redireciona. María Gabriela Lugones (2012) é elucidativa a esse respeito ao colocar sob suspeição esse pressuposto centralizador atribuído ao judiciário, atentando para as margens de manobra de que se valem as funcionárias dos Juizados Prevencionais de Menores, em Córdoba, Argentina. Chamando essas funcionárias de "pequenas juízas", sua etnografia coloca em relevo seus afazeres burocráticos do cotidiano de trabalho, os quais são tão essenciais no andamento dos processos judiciais quanto o são para seus desfechos (Lugones, 2012:126). Nesse sentido, embora os encaminhamentos de pedido de avaliação psiquiátrica sejam feitos pelo judiciário, desloco a atenção para como o diretor se apropria do que concebe como uma "desorganização de fluxo" para influenciar o destino de uma pessoa dentro da malha carcerária.

Ouso, então, interpretar a coincidência arquitetônica da sala de diretor com um tribunal não apenas como coincidência estética, mas de ordem funcional. Os três símbolos imponentes acima de nossas cabeças - o crucifixo e os emblemas do Estado de São e da República - parecem falar de um poder, tanto quanto os escritos em sua lousa, que avaliza moralmente a falsidade do "quadro psíquico" a partir de um laudo psiquiátrico para concretizar uma transferência de unidade prisional para HCTP. Ao manipular papeis, assim como fazem as funcionárias etnografadas por Lugones com seus autos, o diretor incide diretamente sobre a vida de quem esses lhe dizem respeito.

Esse caso em específico também parece dialogar com a interrelação entre "corpo, lei e disciplina", prisma metodológico para o qual Das e Poole (2004) chamam a atenção numa análise antropológica do Estado. Partindo do aporte foucaultiano de "biopolítica", 
argumentam as autoras que o "espaço" formado por esse tripé é um dos possíveis conceitos de "margem". A "margem", assim, seria um "local privilegiado" de onde se observar uma certa "colonização da lei" por algumas "disciplinas" e, nesse ponto, destacam o papel da medicina como mecanismo através do qual opera o "biopoder" do Estado, cujo governo recai não somente sobre territórios, mas sobre corpos. A definição do indivíduo "normal" é parte integrante desse mecanismo, no qual o discurso de patologias é "parasitário" da lei, na medida em que se vale de seus "repertórios" para o exercício de poder (Das e Poole, 2004:10, tradução minha).

Tais enfoques analíticos, sensível ao nível das "práticas" do Estado, são particularmente rentáveis para pensar sobre as imbricações e, consequentemente, indefinições entre "margens" e Estado. O poder de que usufrui o diretor desafia um olhar unidirecional ao judiciário como foco de poder, mostrando como o HCTP, ao mesmo tempo que pode ser entendido como uma "margem", porquanto é receptor de ordens jurídicas, não o é enquanto categoria que é oposta ou subordinada ao Estado. O HCTP, na figura institucional do diretor, "coloniza" a lei, aproveitando a palavra empregada por Das e Poole (2004), para agenciamentos próprios, incidentes sobre os corpos da população carcerária. É didática a imagem que as autoras fazem para conceituar “margem”. Como rios, elas não jazem fora do Estado, mas “correm através do seu corpo"; tais polos são, portanto, contingentes e maleáveis (ibid:13, tradução minha). Do ponto de vista de pacientes-detentos(as), também podemos ver mecanismos de como as “margens", dessa vez referida à população custodiada, mimetizam e apropriam-se da linguagem do Estado, este na figura do médico psiquiatra ou diretor. Tanto com os dois rapazes que encontramos em Taubaté quanto no caso de Claudio, percebemos um agenciamento de regras do Estado para a produção de resultados desejados.

Interpelar a reflexividade das categorias de "Estado" e "margem" é igualmente relevante para situar nossos próprios agenciamentos, como GT, ao nos inserirmos no contexto de visitas. Dito de outro modo, reivindicar o fechamento dos HCTPs em consonância com a diretriz ao mesmo tempo antimanicomial e abolicionista penal dependia de um enfrentamento ao "bom trabalho" que nossos interlocutores reivindicavam fazer. Como vimos, um dos argumentos que embasavam a qualidade era a motivação do cuidado, do fazer o bem, por parte dos(as) funcionários(as). Aliado a esse fator, existiam argumentos de ordem temporal, para além do de ordem espacial mobilizado para designar como "melhor" o espaço de um HCTP frente a um presídio. 
Essas legitimações temporais ficam evidentes nas diversas clivagens entre "antes" e "depois", que despontam em várias das situações narradas. A questão do nascimento das alas psiquiátricas em presídios e a consolidação de um certo fluxo organizado aos HCTPs é contrastada com o cenário nefasto anterior da pulverização da população de segurança nas prisões paulistas; a melhora da "paciente" desde que chegou ao HCTP, vinda de uma ala psiquiátrica, é apontada pela enfermeira como uma evidência da qualidade de seu trabalho; a rebelião de meados do século XX e que resultou na carbonização de muitos é fato abominável de um passado que não condiz com a excelência atual da instituição, excelência essa também que parece exorcizar uma já ultrapassada "educação mais punitiva" em contraste com os "novos ares" atuais . Mesmo no caso em que os "anos dourados" não se localiza no presente, mas num passado nostálgico, o abominável não é visto necessariamente como operante no presente: o retorno ao HCTP é consequência banalmente naturalizada pela falta de uma assinatura alhures.

Argumento que essa valoração do espaço, tempo ou do trabalho pelo contraponto a outros cenários degradantes é parte da "economia moral" mobilizada. A atitude do pai que ajuda à revelia da lei, por exemplo, demonstra como a benevolência é dependente, e não exatamente mitigadora, de contextos de precariedade. Em outras palavras, as condições desumanas dos presídios são uma condição de existência para essa moralidade uma vez que, em última instância, sua atitude de "ajudar" não contribui para uma melhoria do sistema carcerário brasileiro em termos de "humanização"; ao contrário, ela se nutre da precariedade para existir.

Essa moral que se nutre da precariedade parece ressoar com o que Soraya Fleischer chama de "cultura da falta" (Fleischer, 2018:121). Sua etnografia de um centro de saúde localizado no Distrito Federal mostra como a precarização do sistema público de saúde faz com que parâmetros mínimos, isto é, aquilo que é direito dos pacientes acaba transformando-se em "ajuda", como se o atendimento médico lhes fosse um favor: "Diante da 'cultura da falta', ser atendido pela boa médica, encontrar a porta da sala de acolhimento destrancada ou receber o bom senso da farmacêutica já seria muito" (ibid:158). Nesse sentido, uma privada como um buraco fétido no chão acaba sendo “melhor" do que viver num CDP com capacidade para 572 vagas, com população de 1545 pessoas (Relatório Tortura, 2018:103). 
Auschiwitz, portanto, por estar sempre em outro lugar ou em outro tempo, ratificava uma postura paternalista, cuja tutela era tão mais necessária quanto fosse a vulnerabilidade dos(as) pacientes-detentos(as) ou a precariedade do lugar de procedência, fosse um presídio superlotado ou uma família "desestruturada", como ouvíamos do vocabulário das equipes de enfermagem. O imperativo de cuidar não deixava de recair sobre os considerados mais inteligentes, uma vez que sua sagacidade, como vimos, podia ser vista como fruto de distúrbio mental.

Do ponto de vista do GT, a constante exportação do lugar de "condições desumanas" para além dos HCTPs, ou, para aproveitar a metáfora de Pe. Chico, de Auschwitz, para o mundo extramuros ou para o passado longínquo colocava-nos o desafio de mostrar onde ele estava na atualidade e, para tal, era fundamental elaborar um conceito de violência que desse conta dessa realidade específica. Com efeito, o espinhoso da questão não era ressignificar o trabalho de funcionários(as) como um "trabalho sujo", afinal de contas o corpo funcional era também as pessoas com as quais nos associávamos a depender das demandas que nos eram solicitadas por pacientes-detentos(as); seu trabalho era importante para que o nosso pudesse ser também realizado.

Do mesmo modo, era contraproducente argumentar que os manicômios judiciários eram mais aviltantes do que prisões. Não somente de funcionários, mas ouvíamos também relatos de pessoas que haviam passado por prisões antes de sua custódia nos HCTPs sobre como a superlotação era um dos principais problemas que fazia do cotidiano uma batalha de sobrevivência. Para algumas delas, estar num HCTP era um verdadeiro alívio. Entretanto, a equiparação entre esses espaços frequentemente levava a uma discussão inútil de disputa de horrores, na qual um horror maior faz o polo comparativo, ainda que terrível, parecer adequado ou reconfortante.

Diante dessa relativização, tento uma aproximação com a metáfora de Pe. Chico e provoco também uma pergunta. O notório campo de concentração Auschwitz, assim como outros campos de extermínio ou de trabalho nazistas, tinham eles também uma frase erguida sobre as cabeças dos que entravam: "Arbeit macht frei" ("O trabalho liberta"). Assim, pergunto: oferecer oportunidades de trabalho ou quaisquer outros serviços faz de Auschwitz um lugar habitável ou desejável?

Desde a perspectiva antimanicomial e sintonizada com o abolicionismo penal propugnado pela PCr, era necessário que o GT provocasse um questionamento mais 
abrangente, interpelando qual o efeito de um "bom trabalho" realizado num "contexto sujo". Esse deslocamento, entretanto, não é algo inédito do GT, pois ele já estava presente na Carta de Bauru, importante documento da luta antimanicomial brasileira, lançado em 1987. Um trecho desse manifesto serve de abertura ao Relatório Hospitais-Prisão, o qual reproduzo abaixo:

O manicômio é expressão de uma estrutura, presente nos diversos mecanismos de opressão (...). A opressão nas fábricas, nas instituições de adolescentes, nos cárceres, a discriminação contra negros, homossexuais, índios, mulheres. Lutar pelos direitos de cidadania dos doentes mentais significa incorporar-se à luta de todos os trabalhadores por seus direitos mínimos à saúde, justiça e melhores condições de vida (Carta de Bauru apud Relatório Hospitais-Prisão, 2018:8).

Como uma citação norteadora de todo o conteúdo que se segue, O Relatório Hospitais-Prisão vincula-se aos dizeres desse documento, procurando lançar luz a esse dilema recorrente nas visitas e alinhavando seu conteúdo com o entendimento do manicômio menos como um espaço físico e mais como uma "estrutura". Dentro dessa matriz semântica, o relatório propõe um conceito de "tortura":

Entendida em sentido mais amplo, a tortura opera como um conjunto de práticas e concepções que extrapolam ações impingidas diretamente sobre o corpo, tais como agressões físicas ou privações de circulação. A relação que a instituição mantém com a sua população é atravessada pela violência em níveis variados, em diversas camadas, desde o rompimento com o mundo exterior, passando pela construção dos sujeitos como perigosos, até a administração de medicamentos como meios contentivos, além do caráter de indeterminação temporal da medida de segurança. Entender o seu significado dessa forma é não isolá-la como um desvio de conduta, seja de um agente de segurança, seja de um enfermeiro, ou como corrupção dos fins a que a instituição serve. A operação dessas instituições, seus protocolos e as diretrizes imperantes corroboram com uma lógica perniciosa que não se restringe, necessariamente, às intencionalidades do corpo burocrático (Relatório Hospitais-Prisão, 2018:46-47).

Fechar manicômios judiciários era importante não por causa dessa ou daquela agressão cometida por um agente de disciplina ou enfermeira - o que não significa dizer que não ocorram - mas por colocar em questão a própria razão de existir dessas instituições, assim como a de unidades penitenciárias. Enfocar na qualidade do trabalho da equipe técnica, portanto, seria desviar o foco do ponto nevrálgico do problema. Como disse certa vez um agente da pastoral carcerária "não se humanizam navios negreiros" referindo-se ao velho problema de tentar tornar o cárcere um lugar mais habitável.

Trata-se de uma proposta de conceituação de violência que não veja Auschwitz aqui ou acolá, numa disputa entre quem performa melhor esse papel: uma prisão comum, 
um manicômio judiciário, ou mesmo a "rua", isto é, a desinternação para um mundo que já não é familiar depois de anos de custódia. Ao contrário, a tentativa consiste em visibilizar o campo de concentração nas "lógicas penais-manicomiais", para usar a expressão do Relatório Hospitais-Prisão, que chama a atenção para a imbricação entre essas esferas. É uma tentativa também que, por isso, não necessariamente se restringe a um espaço físico, mas procura abrir o foco para as múltiplas interfaces entre eles, colocando sob crítica os fluxos e legitimações dos agenciamentos a partir das justaposições e relativizações espaço-temporais ao estilo melhor/pior ou antes/depois. As alas psiquiátricas, por exemplo, se fazem presentes dentro dos HCTPs quando emergem as tensões referentes a mistura de distintos "perfis", o que dispara, por sua vez, preocupações de cuidado e tutela sobre aqueles "mais frágeis", que serão vítimas de suborno ou extorsão, os "realmente psiquiátricos". Essa cadeia de acontecimentos e os marcadores que passam a operar não podem ser entendidos quando dissociados da preocupação de se atentar para os "vasos comunicantes" entre prisões e HCTPs, isto é, os circuitos que conectam os espaços prisionais com outras instituições e espaços urbanos (Godoi, 2015).

Em suma, o que fica patente das experiências de visita é como os manicômios judiciários existem por causa e em contraponto a uma miríade de contextos espaçotemporais que os atravessam e fazem deles uma instituição, se não desejável, necessária. Como consequência, foi inescapável ao GT que elaborasse uma linha argumentativa no relatório e, na sua esteira, um conceito de "tortura" que não perdesse de vista o olhar para essas fronteiras permeáveis, as quais são pilar central do argumento de que o simples fechamento de HCTPs é inócuo se o olhar penal abolicionista ignorar um contexto mais amplo e complexo, repleto de conexões.

Ocorre que, se por um lado a escolha desse ângulo como forma de visibilizar a violência e o enfrentamento às "lógicas penais-manicomiais" lança luz para os emaranhamentos que transcendem os HCTPs, por outro, ele interpela nossa própria posição, enquanto GT, nessa “malha jurídico- psiquiátrica” (Relatório Hospitais-Prisão, 2018:22).

Ainda que não fôssemos um espaço físico por onde circulam pacientesdetentos(as) e nem sempre virtuosos ao mobilizar as agências estatais para a resolução de questões processuais ou de serviço social, é inegável que a lente através da qual vemos o 
manicômio como "expressão de uma estrutura" implica perscrutar o papel que temos nela, cuja posição como visitantes nos faz um ponto por onde circulam, se não corpos, muitas palavras. Assim, a política de visitas da PCr não nos faz meros expectadores dos fluxos debatidos até aqui, pois existe um grau de incidência no cotidiano dessas instituições que nos joga também para as interfaces entre prisões e HCTPs, suscitando questionamentos morais não tão distantes daqueles que formulávamos a respeito de funcionários(as).

Como ponto de partida dessa discussão, recoloco o diálogo que propus com o trabalho de Hughes (1962). Como dito, de acordo com a linha abolicionista penal, não se tratava de disputar a concepção de funcionários(as) de seus "bons trabalhos" tentando convencê-los de que eram, na verdade, "trabalhos sujos", mas de provocá-los a pensar na efetividade de "bons trabalhos", podendo vir de "boas pessoas", porém em "contextos sujos". Ao mesmo tempo que essa perspectiva foge de responsabilidades individuais, ela porta uma aplicabilidade tão pertinente ao corpo funcional dos HCTPs quanto aos propósitos do trabalho pastoral. Pode-se dizer que visitar unidades prisionais ou manicômios judiciários com a justificativa de provisão de "assistência humanitárioreligiosa" sugere a adesão a um "bom trabalho", podendo ser realizado por "boas pessoas" e em "contextos sujos".

Abrir o campo de visibilidade para nossa implicação nesse contexto nos enleava com as "tramas de sentidos" em suas dinâmicas atravessadas por "afetos", fazendo dos nossos caderninhos "páginas" e "páginas" das tentativas de captação da experiência por meio da escrita. De tanto visitar, parece que nos tornamos parte da "casa" onde, assim como "pedras" são conclamadas a virarem "degraus", "narrativas" transformam-se na "palavra tradicionalmente silenciada pelos muros prisionais", como dito no lançamento do relatório, cuja transmissão a outros planos é o mote de concretização de "um mundo sem cárceres". Essa reflexividade entre "casa" e GT nos leva de volta às muitas experiências que interpelam a desejada transmissão de narrativas e aqui foco minha atenção a uma delas, aparentemente insignificante: a escrita tremida de Nathan. Seu pequeno pedaço de papel entregue em minha mão através da apertada abertura de sua cela talvez possa ser lembrete de algo mais abrangente que a matrícula no curso de português. Sua escrita, através de sua demanda, fala também tanto de transmissão quanto de rememoração. 
Na história do GT, a epítome desse par transmitir-rememorar por meio da escrita é a produção do Relatório Hospitais-Prisão, o qual, assim como sugerem os interstícios entre GT e HCTPs, não deixa de ser parte da "casa" e de suas "tramas de sentido". Em outras palavras, seu intento de transmissibilidade de "ecos" e "vestígios" de outros, recuperando as palavras de Pe Chico, vem acoplado à intenção política de evitação do esquecimento das palavras de pessoas consideradas silenciadas. Essa preocupação de rememorar vozes alheias reverbera na segunda tese do famoso artigo de Walter Benjamin, Teses sobre o Conceito de História, a qual convida-nos à seguinte reflexão: "Não existem, nas vozes que escutamos, ecos de vozes que emudeceram?" (Benjamin, [1940] 1987:1). Sua pergunta reflete uma fração de seu trabalho intelectual centrada justamente na transmissibilidade da experiência e recuperada pela filósofa benjaminiana Jeanne Marie Gagnebin.

Debruçando-se sobre dois ensaios de Benjamin - $O$ narrador e Experiência $e$ Pobreza - os quais mobilizam uma mesma lenda chamada "O velho vinhateiro", Gagnebin (2006) tece interpretações que se fazem na interface entre transmissão da narração e o papel do narrador. Resumidamente, a lenda versa sobre um velho vinhateiro que, em seu leito de morte, confessa aos seus filhos que um tesouro está soterrado no vinhedo da família. Eles, então, cavam todo o terreno, mas nada encontram. Chegado o outono, porém, o revolver do solo fez com que suas vindimas vicejassem como as mais primorosas da região e eles reconhecem, assim, que a riqueza era, não um tesouro, mas a própria experiência que a mensagem do pai proporcionou. Rechaçando uma leitura moralizante e simplista que redunda na valorização do trabalho e esforço, Gagnebin prefere uma interpretação que enfoca naquilo que é dito desde uma posição limiar, a saber, entre a vida e a morte, e que aciona, por meio da escuta, a ação da geração procedente. $\mathrm{O}$ valor da mensagem, portanto, não se encontra no seu conteúdo, mas no potencial de transmissibilidade que excede a "existência individual de cada um de nós"; que é transgeracional e "maior que as pequenas experiências individuais" (Gagnebin, 2006:50).

A preocupação de Benjamin subjacente à evocação da lenda está relacionada ao que chama de "perda da experiência", algo, a seu ver, característico da modernidade, cuja principal marca seria o estabelecimento de outros gêneros narrativos, notadamente o Romance, que teria como principal atributo o individualismo em detrimento da coletividade. O desaparecimento "das formas tradicionais de narrativa, de narração, que 
têm sua fonte nessa comunidade e nessa transmissibilidade" seria oriundo de uma dupla causa: a intensificação do processo produtivo capitalista e as atrocidades da Primeira Guerra Mundial, cujos horrores teriam obliterado a capacidade de narração. Um dos pontos centrais de seu argumento, contudo, é que a narrativa tradicional não é algo findo e pertencente a um passado distante e nostálgico, mas algo que subiste nos "cacos" e nas "ruínas" da produção de formas hegemônicas do narrar no contexto moderno (ibid).

A tarefa do historiador para Benjamin, diante desse cenário de devastação, seria análoga à imagem do "narrador sucateiro", cujo olhar está atento às "migalhas da tradição", aos "cacos, restos e detritos" de um passado que carrega uma "experiência" e que deve ser rememorado não porque morto e pregresso, qual numa disposição temporal linear, mas que se inscreve coetaneamente no presente (ibid:53). Gagnebin assim sintetiza esse empreendimento:

O narrador e o historiador deveriam transmitir o que a tradição, oficial ou dominante, justamente não recorda. Essa tarefa paradoxal consiste, então, na transmissão do inenarrável, numa fidelidade ao passado e aos mortos, mesmo - principalmente — quando não conhecemos nem seu nome nem seu sentido (ibid:54).

Assentando-me nesses aportes, gostaria de chamar a atenção para o que a entrega do bilhetinho de Nathan tanto (não) pode nos dizer sobre a escrita do Relatório HospitaisPrisão e seu reverso, ou seja, o que este (não) nos diz sobre o bilhetinho. Dito de outro modo, considerando que ambos, como disse antes, têm como denominador comum o par transmitir-rememorar através da escrita, interrogo o que eles poderiam transmitir, de modo análogo à lenda do velho vinhateiro, algo não circunscrito ao conteúdo. Tomando essa indagação como ponto de partida, cito um excerto da introdução do relatório:

Se os integrantes do Grupo de Trabalho consideram fundamental a observação sobre os espaços de internação, assim como as conversas e o contato com os vários atores que transitam por esses locais, vale dizer que as ações propostas não se restringem ao lado de dentro dos muros, uma vez que a lógica asilar e punitiva, que enreda esses espaços faz-se presente para além deles. No entanto, considera-se urgente ventilar o que ocorre nos Hospitais de Custódia e Tratamento Psiquiátrico. Sabe-se pouco, fala-se pouco, grita-se pouco em relação à persistência desses espaços de internação.

Desse modo, para além de visitas sistemáticas, o GT realiza reuniões frequentes entre os seus membros, a fim de consolidar as observações realizadas, encaminhar as demandas dos pacientes-detentos e refletir sobre o encarceramento hospitalar. Ademais, debates e discussões com entidades da sociedade civil organizada, pesquisadores, trabalhadores da 
saúde e outros interessados na temática também já foram realizados. Desta mobilização, surgem articulações com os mais variados atores do poder público e da sociedade civil, bem como ações que visam construir outros horizontes políticos, com o intuito de somar ao debate sobre a questão de saúde mental (Relatório Hospitais-Prisão, 2018:18).

Esses dois parágrafos colocam em relevo dois pontos principais: (i) a premência da transmissibilidade, metaforizada pelas ideias de "ventilar", "saber", "falar" e "gritar"; (ii) que essa transmissão não é passível de ocorrência sem a articulação com uma miríade de "atores".

Entretanto, o que se fala ou se grita sob a óptica que privilegia "lógicas penaismanicomiais" não é como Daiana faz para se sentir feliz dentro do HCTP e tampouco sobre o bilhetinho de Nathan para ser matriculado no curso de português. Suas histórias simplesmente não estão lá, a não ser prensadas por acachapantes expressões genéricas como "população em medida de segurança". De certa forma, o ato de "gritar" não se faz sem o silenciamento da "palavra" que se busca transmitir.

Não obstante o silenciamento, porém, os "cacos", sejam os de vidro com que Daiana usa para seus cortes, suas palavras, ou mesmo os bilhetinhos de Nathan, têm seu viés denuncista, tanto quanto o tem o texto do relatório. Eles denunciam aquilo que não foi ou não pôde ser apreendido em sua totalidade quando se escolhe uma determinada maneira de contar histórias; são demonstrações da falha do intento de "tornar histórico o que fora escondido da história" (Scott, 1998:298). O bilhetinho de Nathan anexado com um clip e prensado até o momento da escrita desta dissertação entre as páginas do meu caderninho parece uma metáfora imagética do que, ainda que na forma de "caco", resiste às camadas e camadas de páginas escritas sobre ele ao longo do tempo; daquilo que insiste em ser rememorado a despeito do apagamento. Afinal de contas, como defende Gagnebin, a escrita não é integralmente marcada por sua intencionalidade, porquanto o ato de escrever é ele mesmo produtor de "rastros": "Rastro que é fruto do acaso, da negligência, às vezes da violência" (Gagnebin, 2006:111).

O problema, no entanto, não é digno da superficial pressuposição de que para ser solucionado basta incorporar rastro à escrita, dando-lhe estatuto equivalente. O pensamento de Joan W. Scott (1998) é certeiro no que concerne ao combate ao que chama de "história normativa" empreendido por historiadores e que vai ao encontro da reflexão de Gagnebin. O seio da argumentação de Scott gira em torno de um equívoco de foco epistemológico, voltado à preocupação de visibilizar a "experiência de outros" deixados 
à margem do discurso histórico hegemônico. Para ela, iluminar o que foi jogado às sombras da história sintetiza uma metodologia de "ampliação do quadro", que, ao trazer para a cena o negligenciado, deixa de questionar o próprio quadro em si, ou seja, "a própria estrutura disciplinar da história" (ibid :300). É um método que, se foi bem sucedido no passado, como reconhece a autora, carece de problematizar a categoria "experiência", que não coloca sub júdice a produção de categorias essencializadas homem, mulher, pobre, homossexual - e tampouco a relação de poder envolvida na omissão de tudo o que diz respeito ao narrador, sob a justificativa da neutralidade e positivismo científico. Sua proposta, entretanto, não propugna pelo abandono do termo “experiência”, não obstante seu caráter acachapante e essencializador de determinadas categorias sociais, mas por uma redefinição semântica:

\footnotetext{
Experiência é sempre e imediatamente algo já interpretado $e$ algo que precisa de interpretação. $\mathrm{O}$ que conta como experiência não é algo autoevidente nem direto; é sempre contestado e, portanto, sempre político. O estudo da experiência, consequentemente, deve trazer à discussão seus status originário na explicação histórica. Isso acontecerá quando historiadores considerarem seus projetos não a reprodução e transmissão do conhecimento vindos, como se diz, através da experiência mas sim a análise da reprodução desse conhecimento (ibid:324, ênfases originais).
}

Entendo que o Relatório Hospitais-Prisão se atenta parcialmente às advertências de Scott. Isso porque menos do que denunciar a existência de "pacientes" e o tratamento aviltante que lhes era destinado, tanto em presídios quanto em HCTPs, o foco era desvencilhar-se de como se deveria dar esse tratamento, ao nível das boas-intenções e especulações, problematizando a forma em si como a categoria de "paciente" é construída. Preocupar-se em como deveria ser o tratamento seria tomar de partida que existe um(a) "paciente" com essa necessidade. Nesse sentido, a escolha do binômio "paciente-detento(a)" para a redação do texto procurou politizar a terminologia a partir da crítica ao pressuposto de que sejam doentes a serem tratados, ao menos no contexto dos HCTPs. Pode-se dizer, até certo ponto, que o direcionamento argumentativo era "não comprar", por força de expressão, a categoria que nos era dada, evidenciando suas nuances e como são construídas no dia-a-dia, construção essa que é eixo central do conceito de "tortura" elaborado no texto. Tal objetivo corrobora a intenção de desnaturalizar uma categoria histórica como a de "paciente", procurando discutir essa experiência desde o percurso do seu "status originário", para usar a expressão de Scott, a partir do contexto de visitas. 
A crítica de Scott é relevante também por sublinhar a ilusão que a "ampliação de quadro" oblitera, ou seja, que a tentativa de visibilização de outros é sempre um trabalho incompleto uma vez que a extensão das molduras do quadro não tem limite. Sempre haverá "outros" a serem incluídos se optarmos pela metodologia de visibilização, tal como ela concebe. Nesse sentido, ter escolhido a terceira cela da esquerda para começar o momento de conversas particulares naquela visita implicou abrir mão de muitas outras miniaberturas. Simplesmente não havia como dar conta de todas frente ao tempo apertado, tornando inescapável minha escolha de emolduração. E, mesmo reduzindo o quadro para apenas uma delas, que, por acaso, era a de Nathan, a operação reproduz o mesmo problema: a experiência não deixa de ser atravessada por "cacos".

Se trazer a história de Nathan, Daiana e de tantos outros à tona não parece ser a diretriz de combate à "história normativa", isto é, aos muros prisionais que silenciam narrativas, como então lidar com o imperativo político de escrever "contra-histórias" (Hartman, 2008:26, tradução minha)? Creio que o relatório cumpre um papel paradoxal de ser um "narrador sucateiro" produtor, em sua escrita, dos "cacos" que ambiciona recolher. Disso decorre que a escrita não é mero registro de algo, mas ela própria uma manifestação de poder, uma vez que "as políticas da memória e da autoria estão inextricavelmente envolvidas com a política do poder institucional em todas as suas formas: casas de família, trabalho doméstico, educação, publicação e recepção" (McClintock, 2010:477).

Essa indissociabilidade de políticas de autoria e memória com poder institucional é a temática norteadora do capítulo 8 de Couro Imperial (2010), de Anne McClintock. Intitulado $O$ escândalo da hibridez: a resistência das negras e a ambiguidade narrativa, o capítulo traz instigantes reflexões sobre a parceria entre duas mulheres, Elsa Joubert, escritora e africâner branca, e Poppie Nongena (nome fictício), uma negra pobre, a quem a primeira seria responsável por transcrever e editar a história de vida da segunda. Essa parceria, que começou em meio ao contexto do levante de Soweto, na África do Sul em 1976, resultou na publicação do livro “A longa jornada de Poppie Nongena”, sendo um sucesso de vendas (McClintock, 2010:434).

A pergunta guia da análise de McClintock é interpelar "quais são as relações de poder entre uma mulher sul-africana negra e outra branca quando uma narrativa oral é transcrita, seletivamente editada e publicada" (ibid:442). Sua interrogação tem como 
desdobramento direto a inseparabilidade entre o modo narrativo do livro e seus interesses sociais e políticos, incluindo o modo como repercutiu na sociedade sul-africana. A disparidade entre a fama internacional da escritora branca com seu lançamento e o ofuscamento de Nongena, mulher negra, "testemunha os desequilíbrios de poder racial e de classe entre duas mulheres e suas respectivas e diferentes relações com o Estado. (...) O escândalo da colaboração feminina entre raças é silenciado, a hierarquia é restaurada e os limites, retraçados" (:446).

Como uma história mediada, em sua íntegra, por Joubert, McClintock opera uma distinção entre autobiografia e "testemunhos", afirmando que esse último é "sempre dialógico e público", ao passo que o primeiro é essencialmente privado no seu escrever. Testemunhos carregam "a marca das vozes dos dois que falam, a natureza dupla da escrita e a autoridade dispersa da voz". A identificação completa com Nongena, portanto, tornase impossível, na medida em que a narrativa "recusa a ceder em um único ponto de identidade", sendo atravessada totalmente por um "desequilíbrio" permeado por "transgressões de classe, de raça e de gênero" (:475). Entretanto, ironicamente, é justamente essa impossibilidade de identificação com um "único eu” narrativo a denúncia da conformação de uma identidade de quem a lê, porque relembra constantemente o leitor do "seu próprio privilégio" que impede "uma identificação catártica com a voz de quem não tem poder", o que impacta, inclusive, na própria acessibilidade de Joubert à experiência de Nongena (:476).

Não podemos, portanto, ignorar as relações desiguais de poder que emanam da tessitura do texto, aspecto esse que, na opinião da autora, "a maioria das histórias orais" negligencia por obliterar a desigualdade, ou tentar fazê-lo, na produção de conhecimento histórico. No romance de Nongena e Joubert, ao contrário, “os desequilíbrios estão flagrantemente lá, inevitáveis, contraditórios e insolúveis, insistindo na disputa interpretativa e na análise política". McClintock nega qualquer possibilidade de que equalizar essa hierarquia passe por uma "redistribuição mais equitativa da identidade puramente narrativa", porque isso, necessariamente, requer uma "correspondência na completa transformação social" (:477).

O paralelo com o romance de Nongena e Joubert que gostaria de fazer na esteira das ricas reflexões de McClintock toma como base uma dupla sobreposição. Em primeiro lugar, tanto quanto o livro sobre a história de Nongena, o Relatório Hospitais-Prisão 
incorpora textualmente as desigualdades que marcam seu testemunho a partir das visitas. Ainda que algumas citações de pacientes-detentos(as) ou do corpo funcional estejam em destaque como maneira de subsidiar os pontos abarcados, o anonimato foi a política norteadora de sua impressão. A despeito da motivação protetora aos relatores que lhe dá fundamento, essa política de "cuidado", dessa vez da parte do GT, não deixa de ser produtora da desigualdade autoral, até pelo fato que a autoria do relatório está devidamente especificada com os nomes dos(as) componentes do GT. Outra questão delicada e que certamente se relaciona com o processo desigualmente marcado de escrita é a não consciência da parte de pacientes-detentos(as) e de funcionários(as) de que estávamos produzindo esse material. A justificativa para tal foi que receávamos um acirramento das estratégias de censura ao nosso acesso aos HCTPs, o que eventualmente caiu por terra pois houve o vazamento de uma versão preliminar para os diretores pouco antes que fosse lançado, imprevisto esse que será discutido no capítulo seguinte.

O segundo ponto que coloco em diálogo com McClintock jaz em sua ideia de que a transmissibilidade da narrativa de Nongena por meio do livro requer, necessariamente, a rememoração contínua do privilégio de quem lê, o qual é marcado pela impossibilidade de identificação com sua voz. É interessante notar, contudo, que tal impossibilidade não é o que impede a transmissão, mas o que denuncia o sentido: trata-se da demarcação do que não pode ser transmitido, fato esse que produz uma experiência cuja desigualdade lhe é uma marca inerente.

Tendo esse pressuposto como base, acredito que a mini abertura da cela de Nathan é análoga a seu bilhetinho: ambos colocam o que é transmitido menos em termos de conteúdo do que da impossibilidade de acesso a uma certa experiência, demarcando o privilégio de quem está do outro lado e recebe o pequeno pedaço de papel. É a flagrante demarcação entre quem detém o poder de escrita e quem é alvo dessa escrita. Entretanto, essa relação autoral é sempre atravessada de opacidade, isto é, do que resta inacessível em termos de identificação, como vemos com Nongena. É essa opacidade que interpela o porquê de dar encaminhamento à demanda de um curso de português é uma tarefa não acessória, mas integrante do objetivo abolicionista penal; é ela também que pode dar inteligibilidade à importância do relatório em consonância com "um mundo sem cárceres", não obstante as opacidades que o próprio texto produz. 
O narrador sucateiro, assim, não é aquele que busca usar os "cacos" como peças para a reconstituição fidedigna de um todo que já não mais existe, senão que procura enxergar quais sentidos do todo emanam desses pedaços e, concomitantemente, respeitar suas incompletudes:

\begin{abstract}
Tal rememoração implica uma certa ascese da atividade historiadora que, em vez de repetir aquilo de que se lembra, abre-se aos brancos, aos buracos, ao esquecido e ao recalcado, para dizer, com hesitações, solavancos, incompletude, aquilo que ainda não teve direito nem à lembrança nem às palavras. A rememoração também significa uma atenção precisa ao presente, em particular a estas estranhas ressurgências do passado no presente, pois não se trata somente de não se esquecer do passado, mas também de agir sobre o presente. A fidelidade ao passado, não sendo um fim em si, visa à transformação do presente (Gagnebin, 2006:55).
\end{abstract}

Tal politização em torno da viabilidade da transmissão e seu compromisso com a incidência no presente a partir do passado vai ao encontro de Hartman (2008) quando esta afirma que a "reconstrução do passado" é tributária da denúncia das violências atuais, numa conjunção entre passado e presente que faz da violência da escravidão um evento contemporâneo. Cito:

Meu esforço de reconstruir o passado é, também, uma tentativa de descrever obliquamente as formas de violência autorizadas no presente, isto é, formas de morte desencadeadas em nome da liberdade, da segurança, civilização, e Deus/do bem (Hartman, 2008:13, tradução minha). ${ }^{50}$

Sem classificar a demanda de matrícula de Nathan como desimportante, minha intenção é discutir em que medida ela a excede em seu conteúdo; em que medida sua cela reverbera as demais; em que medida ela pode falar de Daiana; e em que medida ela fala de nós. Dito de outra forma, provoco o questionamento de perscrutar até que ponto seu bilhetinho, no contexto específico de nossa interação, transcende uma experiência individual, denunciando outra coletiva que não é somatória de várias individuais, mas aquilo que nos implica pelo que não pode ser completamente entendido, porque denuncia, no limite, o privilégio de quem detém o poder de escrever. Essa implicação pode ser entendida nos termos que Gagnebin e Hartman colocam como compromisso de uma rememoração do passado a serviço da transformação do presente, assim como o faz a lenda do velho vinhateiro, que prescinde do conhecimento da mensagem em si,

50 "My effort to reconstruct the past is, as well, an attempt to describe obliquely the forms of violence licensed in the present, that is, the forms of death unleashed in the name of freedom, security, civilization, and God/the good". 
transmitindo-se para outra geração e provocando-lhe uma experiência que não é a do remetente da mensagem.

Seguindo essa linha, a tentativa de fugir dos termos do debate com o corpo funcional dos HCTPs ao estilo antes/depois, melhor/pior é transpassado pela provocação de um olhar limiar, fronteiriço, que procura entender o quanto do antes existe no depois a despeito da melhora da otite, ou da "ajuda" ao ser transferido de um presídio "desumano", a fim de propor um outro ângulo de visibilidade. A "rede prisionalmanicomial" talvez enleie não somente quem está direta ou indiretamente enredado - a população encarcerada e seus familiares, enfermeiras, diretores, agentes pastorais, juízes, defensores públicos e assim por diante - mas até mesmo aqueles(as) que não se pensam como implicados(as), que se julgam distantes do seu epicentro, se é que ela possui um. Por prescindir do conhecimento, a transmissibilidade dessa experiência por meio da escrita recai numa alteridade que não supõe que as pessoas saibam como é sofrer com o encarceramento ou o que é viver num manicômio judiciário uma vez que as palavras do relatório jamais poderiam carregar a experiência que nunca foi a de seus autores.

Antes, ela implica através opacidade, inclusive através de uma escrita que produz as suas próprias e cuja desigualdade autoral, como assevera McClintock, não será minada senão pela "completa transformação social", o que, em nosso caso, seria a efetivação de “um mundo sem cárceres”. O opaco, assim, não é pura ausência, mas bússola de nossa posição em relação ao encarceramento: seu desconhecimento é fruto também de um dos seus efeitos, a saber, do privilégio de que não precisamos saber; de que ele não é uma preocupação. E, num contexto em que o fechamento de todas as prisões (e manicômios judiciários) soa como utopia, esse talvez seja o mais longe que uma escrita penal abolicionista possa chegar: contar histórias que nos provoquem a "ver" "cacos" para que vejamos a nós mesmos de outra forma: imersos na coletividade eivada de desigualdades que nos implica. Somente revolvendo a terra em conjunto poderemos ter a expectativa de que algo possa, quiçá, vicejar. 


\title{
Capítulo 3: Abolicionismo penal como histórias sem inícios e fins
}

\author{
O passado só se deixa fixar, como imagem que \\ relampeja irreversivelmente, no momento em que é \\ reconhecido. (...) Pois irrecuperável é cada imagem \\ do passado que se dirige ao presente, sem que esse \\ presente se sinta visado por ela (Benjamin, 1940:2).
}

Histórias são eivadas de imprevistos em seus enredos, mesmo aquelas que se nos apresentam como as mais lineares. Uma vez tendo discutido os processos de escuta e de escrita das histórias com as quais nos enredamos através das visitas, o último capítulo desta dissertação almeja colocar em questão seus inícios e fins. Para onde elas nos levam? Em que ponto traçamos seus começos e demarcamos seus fins? Tais demarcações são relevantes para o que se propõe politicamente para a consecução de "um mundo sem cárceres"? Trago dois episódios ocorridos durante o período em que atuei como agente pastoral e tive participação direta nos acontecimentos descritos. Acredito que eles nos provoquem a respeito de onde e como colocamos nossas maiúsculas iniciais e pontos finais.

\section{Documentos em seus próprios itinerários}

Quinta-feira, dia 16 de agosto de 2018. Era chegado finalmente o dia de lançamento do Relatório Hospitais-Prisão. Poucas horas antes, no entanto, a certeza de que o evento ocorreria foi drasticamente abalada. A quinta-feira era justamente o dia da semana que fazíamos nossas visitas aos dois HCTPs de Franco da Rocha e, naquela manhã, eu e alguns colegas do GT participamos do que julgávamos ser, possivelmente, a última visita dado o provável impacto negativo que as repercussões do documento teriam para o nosso acesso aos manicômios judiciários.

Chegando ao HCTP, como esperávamos, a notícia de que o relatório seria lançado em algumas horas já se fazia saber no corpo de funcionários e diretoria da instituição. $O$ que foi completamente inusitado, porém, foi que não somente o evento era sabido, mas uma versão preliminar do relatório, com marcas de edição e comentários de revisão com identificação dos autores, encontrava-se nas mãos do diretor que nos recebia em sua sala. Ficamos perplexos com o vazamento de uma versão que, até então, circulara única e exclusivamente, mediante razões específicas, nas instâncias internas da PCr e nos e-mails 
pessoais dos membros do GT. Enquanto o exemplar impresso era exibido e folheado pelo diretor, a conversa se desenrolou com ameaças de que a insatisfação era generalizada entre os funcionários, sobretudo em meio aos médicos psiquiatras, que, segundo as palavras do diretor, entendiam o material como publicação caluniosa e ofensa direta à área psiquiátrica e, por isso, tomariam providências jurídicas cabíveis aos responsáveis por sua redação e veiculação. Após sucessivas tentativas de argumentação aos pontos levantados por sua leitura, a conversa terminou com a insinuação de sua parte de que, não obstante todos os preparativos, ainda era possível suspender o lançamento, previsto para aquela noite, evitando a consecução das retaliações anunciadas. Além disso, ainda que não de modo explícito, foi sugerido que a renovação de nossas carteirinhas, as quais garantem o acesso às unidades, poderiam ser suspensas.

$\mathrm{O}$ baque de tais ameaças veio a acumular-se junto a outro imprevisto, desta vez interno à $\mathrm{PCr}$, que nos havia surpreendido apenas alguns dias antes. Por ser um material a ser publicado com o nome da PCr, o texto finalizado circulou entre o coordenador nacional (que é também coordenador a nível arquidiocesano e latino-americano, como dito ates), o vice-coordenador da PCr da Arquidiocese de São Paulo e o coordenador estadual, para que revisassem e sugerissem alterações ou acréscimos. Nesse tempo de ida e vinda de marcações, rasuras, comentários e edições, o "tom do relatório" foi pauta recorrente e espinhosa, uma vez que fazia afirmações contundentes dos HCTPs como exemplo de "instituição que realiza de maneira sistemática práticas torturantes" (Relatório Hospitais-Prisão, 2018:46).

Como resultado, então, deu-se uma série de discussões com essas instâncias sobre um certo ajuste de tom, que ocorrera também internamente ao GT durante a redação do relatório, tentando balanceá-lo com o contexto delicado de restrições das visitas, mencionado no item anterior. Ocorre, porém, que enquanto o Escritório Nacional e a Arquidiocese posicionavam-se a favor de um tom mais combativo, o Escritório Estadual ia na contramão, advogando por um tom "mais diplomático", nas palavras do coordenador estadual. Semelhante clivagem também dividiu opiniões no GT, o qual já se encontrava, à época de redação e finalização do texto, cindido em duas equipes. Cabe esclarecer que, embora as duas equipes continuassem utilizando a identificação como PCr, a identificação enquanto GT continuou para os que pertenciam à "parte mais social”. A outra equipe demarcou explicitamente o distanciamento em termos de envolvimento frente ao material tanto para as instâncias da PCr, quanto para as dos HCTPs. 
Devido a esses tensionamentos, a poucos dias antes do lançamento do relatório, o coordenador estadual solicitou a retirada do seu nome da contracapa do documento, com a alegação de que não era possível "passar por cima da hierarquia da Igreja". Ainda que nos tenha surpreendido a súbita demanda de retirada do nome, era do nosso conhecimento uma reunião que ocorrera tempos antes entre ele, o secretário da SAP e o bispo referencial nacional da $\mathrm{PCr}$, cuja pauta principal era as restrições às equipes pastorais que seguiam acontecendo, desde a rebelião na penitenciária masculina de Lucélia, nas unidades penitenciárias. Os encaminhamentos ali acordados não ficaram claros, nem mesmo para o Escritório Nacional, mas concluímos que a inesperada atitude, considerando ainda que o coordenador estadual havia feito contribuições ao texto do relatório, era decorrente do que lá foi deliberado e, muito provavelmente, a menção ao respeito à "hierarquia da Igreja" nos permitia inferir uma consonância entre os interesses discutidos, para os quais o relatório era uma ameaça. Embora a retirada de seu nome tenha sido feita, as coordenações nacional e arquidiocesana mantiveram suas identificações no documento.

De pé diante de sua mesa, observávamos, um tanto apreensivos, o folhear das páginas do relatório pelo diretor enquanto ele fazia seus comentários e advertências. No que diz respeito aos pontos por ele levantados, as principais objeções giravam em torno do que decidimos nomear de "práticas torturantes". Ideias semelhantes como "tortura estrutural"(:26), “espaços de aniquilação”(:61) e “espaços de confinamento"(:22) eram diferentes expressões ao longo do texto que buscavam dar forma ao conceito de violência que reivindicávamos, norteador da produção coletiva do documento e cujas intenções foram discutidas no capítulo anterior.

Ainda que houvéssemos tentado, naquela tensa conversa com o diretor, exprimir brevemente nosso entendimento, semelhante à discussão que teríamos com a equipe de enfermagem na visita seguinte ao lançamento do documento, a escuta não nos foi favorável. Nossas palavras rebatiam em defensivas de que nosso material era calunioso e, uma vez terminada o que foi uma das visitas mais delicadas na história do GT, a tarde que se seguiu foi absolutamente tomada por discussões entre nós e as instâncias nacional e estadual da PCr, a fim de deliberar sobre a possibilidade de suspensão do evento.

O argumento mobilizado pela coordenação estadual era de que, num cenário hostil de relações entre a PCr e o Estado, no qual seguiam as restrições e negociações para a normalização de visitas, o lançamento contribuiria tão somente para aumentar a 
probabilidade da proibição total de todas as visitas de assistência religiosa. O episódio também dividiu opiniões internamente ao GT, sendo o argumento a favor à manutenção do evento de lançamento do relatório aportado no fato de que seu adiamento baseado na esperança do arrefecimento dessas tensões mais amplas entre PCr e Estado era uma aposta ingênua. Isso porque, devido a vários fatores, sobretudo à provável eleição de Jair Bolsonaro à presidência da República, o recrudescimento da hostilidade no sistema carcerário a nível nacional era quase uma certeza.

Depois de muitas idas e vindas, reiterações, contra-argumentos, réplicas e tréplicas, todas apertadas pelo tempo que avançava anunciando a proximidade do evento, foi tomada a decisão de que o manteríamos confirmado apesar das ameaças.

$* * *$

Novamente temos uma situação em que os documentos instauram dissidências e ocasionam impactos nos diversos fluxos institucionais, tanto entre instâncias da PCr quanto nos trânsitos entre PCr e HCTPs, sendo sua publicização o ponto delicado que incide em entradas e saídas, aproximações e distanciamentos. Evidência disso é o episódio entre as notas lançadas pelos Escritórios Nacional e Estadual, fato esse discutido no capítulo 1. Tanto lá como aqui, a metáfora de documentos como "campos de força" de Stoler (2010) nos ajuda a entender as atrações e repulsões que as disputas em torno deles engatilham, muito bem ilustradas pela sua ideia de "forças centrípetas" (centripetal forces) e "centrífugas" (centrifugal forces) acionadas por suas dinâmicas (Stoler, 2010:22). A autora faz essa aproximação com a linguagem da física mecânica para, no seu caso de estudo, denotar as "energias analíticas" (analytic energies) mobilizadas pelo Estado colonial na inscrição documental de suas asserções (ibid).

Entretanto, meu foco agora dirige-se para os elementos de opacidade e imprevisibilidade imanentes às energias analíticas que dão origem às escritas grafadas. Para o primeiro, Stoler sugere outra interessante metáfora: a "marca d'água" (watermark). Como impressões de características bem particulares, elas dependem de certo ângulo de visão e luz para serem notadas e são impressas duplamente na superfície e no veio dos papeis, de forma que sua tentativa de remoção ou apagamento não acontece sem a destruição do próprio documento em que se localiza. São, portanto, "assinaturas de uma história" (signatures of a history) que podem ser desveladas a partir da captura do correto 
ângulo de visibilidade, dizendo tanto para além do seu conteúdo quanto dos sentidos ocultos que, aparentemente, não estão no papel (ibid:8).

No que diz respeito à imprevisibilidade, a autora salienta que documentos têm “itinerários próprios", desafiando seu entendimento como registros cristalizados em que todo o dissenso e afetos mobilizados dão lugar exclusivamente ao técnico e racional. Ao contrário, eles são "substâncias generativas com histórias" e não apenas expressão literalizada de uma:

\begin{abstract}
In these chapters Dutch colonial archival documents serve less as stories for a colonial history than as active, generative substances with histories, as documents with itineraries of their own. What was written in prescribed form and in the archive's margins, what was written oblique to oficial prescriptions and on the ragged edges of protocol produced the administrative apparatus as it opened to a space that extended beyond it. (...) Against the sober formulaics of officialese, these archives register the febrile movements of persons off balance-of thoughts and feelings in and out of place. In tone and temper they convey the rough interior ridges of governance and disruptions to the deceptive clarity of its mandates (Stoler, 2010:2).
\end{abstract}

Procuro dialogar com os aportes de Stoler sustentando que a disputa conceitual causada pela controvérsia das expressões é indissociável do caráter político, ou, das "energias analíticas" que jogam luz aos processos e afetações que lhe deram origem. O dilema aqui consiste em assumir que essas práticas de nomeação, relativização ou de omissão ao que estaria no texto final não só são parte da construção do texto, mas imanentes também à construção da posição política de seu autor, bem como das aproximações e distanciamentos estabelecidos com demais atores envolvidos na circulação dos papeis.

Quero dizer, então, que construir um texto, e aqui entendo "construção" como um conceito amplo, abarcando desde o engajamento efetivo na sua redação até a emissão de uma opinião sobre seu conteúdo, ou mesmo a retirada de assinatura do produto final, envolve, necessariamente, estar enredado no processo de confecção e no campo de forças operacionalizados pelos documentos. A reunião a portas fechadas, por exemplo, muito provavelmente não vem dissociada da retirada de uma assinatura, assim como os posicionamentos políticos confluentes de outros atores redundam na manutenção das outras na contracapa do relatório. A metáfora da "marca d'água", portanto, ajuda-nos a pensar que a retirada de assinatura não é mera ausência no papel, mas aquilo que deixa uma marca passível de ser legibilizada sob determinadas angulações. 
A imprevisibilidade do percurso dessas "substâncias com histórias" também foi um capítulo da própria história do processo de confecção do relatório, nas múltiplas idas e vindas em caixas de entrada de e-mails, com rasuras, acréscimos e comentários. Esses percursos virtuais fugiram de nosso controle, enquanto GT, e desembocaram, imprevisivelmente, na mesa do diretor de um dos HCTPs, que folheava uma versão impressa e inacabada do documento justamente no dia de seu lançamento. Assim, a decisão da manutenção do evento não é fruto de uma trajetória premeditada desde seu início, mas algo que, por sua quase não realização, acabou se devendo a uma tentativa delicada de fazê-lo acontecer a partir de um desvio imprevisto dos vários "itinerários próprios".

Após o lançamento do relatório, foi-nos dada a notícia de que o arcebispo de São Paulo, em alinhamento ao secretário da SAP e coordenador estadual, havia dado a ordem de que qualquer relatório ou documento a ser lançado pela $\mathrm{PCr}$, incluindo o Escritório Nacional, deveria ter o aval do assessor espiritual a nível nacional, este um padre. $\mathrm{O}$ coordenador nacional, também um padre, não obstante tenha repudiado veementemente tal comando, viu-se, então, constrangido pela hierarquia eclesial da qual faz parte e que indiretamente nos afeta como grupo vinculado à Arquidiocese, deixando-nos sem opção a não ser assentir. Até aquele momento, no entanto, embora as visitas não estivessem proibidas, as restrições a algumas instalações dos HCTPs pelo GT agravaram-se substancialmente.

O imprevisto também foi algo com que tive que lidar em, praticamente, todas as visitas que participei. Porém, entendo "imprevisto" não somente em seu sentido de inesperado, na ideia de abrupto que a palavra dispara, qual o susto instantâneo de cruzarmos a porta da diretoria e ver nosso relatório em mãos indesejadas. Tanto quanto havia os sustos, havia imprevistos no sentido de que, por mais que tentássemos planejar uma visita, o plano dificilmente daria conta do que eventualmente nos seria demandado, bem como dos imprevisíveis acionamentos decorrentes dos pedidos feitos por pacientesdetentos(as). Cada "escuta", portanto, era o início de um desdobramento de histórias...mas será que o era? Um desses desdobramentos me marcou tanto pelo período em que estive envolvido, quanto pela dimensão do que deveria ser colocado em movimento. Começo, então, a contar a história de Mercedes. 


\begin{abstract}
Abolicionismo penal: histórias com e contra o Estado
"Caio, você precisa falar com minha família para eu chamar o "pessoal dos direitos humanos' aqui e resolver o problema do meu filho"

Foram muitas as vezes que ela repetiu essa frase. De repente, lá estava ela na ala feminina do HCTP I. Conheci Mercedes pela primeira vez no CDP Feminino de Franco da Rocha, meses antes desse encontro repentino. Visitei essa unidade, na qualidade de agente pastoral, durante um curto período e de modo paralelo às visitas aos HCTPs. Como dito antes, essa é uma das unidades penitenciárias que dispõem de ala psiquiátrica e onde muitas sentenciadas com medida de segurança aguardam vaga para os manicômios judiciários.
\end{abstract}

Foi durante uma de minhas visitas ao CDP Feminino que vi Mercedes, esperando sua vez para falar comigo em meio a um pequeno grupo de mulheres que se organizava para trazerem suas demandas a mim. Chegado seu momento de falar, Mercedes sentou ao meu lado no chão de concreto do pátio aberto daquele raio, ainda um pouco úmido devido à chuva que acabara de cair. Sentados ali, contou-me que precisava de minha ajuda para que seu filho mais novo, Marcos, não fosse adotado.

Segundo o que me relatou nos breves minutos que conversamos, uma vez privada de liberdade, três de seus quatro filhos haviam passado para a guarda de seus irmãos e do ex-marido. Marcos, entretanto, que era fruto de uma relação afetiva anterior de Mercedes, sob mando do Conselho Tutelar, foi encaminhado para um Serviço de Acolhimento Institucional para Crianças e Adolescentes (SAICA) onde aguardava ser adotado totalmente à revelia da vontade de Mercedes. Juridicamente, a adoção familiar seria possível mediante um processo de destituição de poder familiar já em curso, mas havia a possibilidade de barrá-lo caso Mercedes aguardasse julgamento em prisão domiciliar.

Com efeito, segundo o Marco Legal da Primeira Infância - Lei 13.257/2016 ${ }^{51}$, mulheres gestantes ou com filhos(as) até a idade de doze anos poderiam ter direito à prisão domiciliar a depender do critério do juiz responsável pelo caso. Não obstante esse elemento de discricionariedade fosse um grande empecilho para que muitas mulheres encarceradas tivessem esse direito respeitado, essa era a única maneira de dar

${ }^{51}$ Para mais informações sobre a lei, ver: https://dp-sp.jusbrasil.com.br/noticias/372567738/comaplicacao-do-novo-marco-legal-da-primeira-infancia-defensoria-publica-obtem-decisoes-que-garantemprisao-domiciliar-a-maes-de-criancas 
encaminhamento ao caso e, assim, acionei a DP-SP, cujo programa Mães do Cárcere $^{52}$ objetiva peticionar o judiciário para dar efeito a essa lei. Isso porque não basta que a pessoa se enquadre nos critérios estipulados; é preciso "provocar" o judiciário, como se diz na terminologia jurídica.

Uma vez feito o contato, por telefone, com uma das defensoras públicas responsáveis por essa iniciativa, esta me assegurou que o caso de Mercedes seria averiguado a partir da inserção de seu nome numa lista com nomes de outras mulheres em privação de liberdade e organizada por sua equipe de trabalho, cujos casos também envolviam a ameaça ao rompimento do vínculo familiar com seus filhos devido ao encarceramento. A estratégia seria impetração de habeas corpus com base no marco legal da primeira infância. Solicitou-me, por fim, que fizesse, se possível, um levantamento de informações a respeito de sua situação familiar a fim de investigar se havia outros parentes que lhe dessem suporte pois isso favoreceria um resultado positivo.

$\mathrm{Na}$ visita seguinte, conversei com Mercedes sobre o que estava tentando fazer e perguntei-lhe sobre o que a defensora me pedira. Forneceu-me, então, os nomes de alguns de seu núcleo familiar e suas respectivas informações de contato. Contra qualquer expectativa, entretanto, pouco tempo após essa segunda visita, encontrei Mercedes na ala feminina do HCTP I. Diante desse fato, tornei a ligar para a defensora pública a fim de entender melhor o que se passara, ao que me foi dito que, tendo averiguado sua situação, Mercedes teve seu processo penal convertido para medida de segurança, com base em perícia psiquiátrica, sendo sua privação no CDP Feminino justificada não pela espera por uma audiência, na condição de presa provisória, mas de sentenciada com medida de segurança aguardando vaga em HCTP. Por fim, foi-me explicado que o programa tinha sua efetividade restrita, a partir do que está previsto no marco legal da primeira infância, a sentenciadas com penas de reclusão e não de absolvição imprópria. Desse modo, seu caso fugia ao escopo do programa Mães do Cárcere.

52 Trata-se de projeto intersetorial da Defensoria Pública do Estado de São Paulo (DPESP), apoiado pela SAP e PCr. Em vigor desde 2012, o projeto tem como principal objetivo garantir a manutenção dos laços familiares entre mães em situação de privação de liberdade e seus filhos e surgiu a partir de demandas relacionadas à maternidade no cárcere levadas à DPESP pela PCr. O projeto atua de modo individualizado a fim de que sejam traçadas estratégias judiciais que evitem a destituição do poder familiar e envolve três Núcleos Especializados da DPESP: Situação Carcerária, Infância e Juventude e Promoção e Defesa dos Direitos da Mulher. Para mais informações, acessar: https://www.defensoria.sp.def.br/dpesp/Conteudos/Noticias/NoticiaMostra.aspx?idltem=44372\&idPag ina $=1 \&$ flaDestaque $=\mathrm{V}$ 
Diante da impossibilidade do acionamento do programa para o caso de Mercedes, tentei rastrear informações que pudessem detalhar a situação de seu filho, mas tudo o que soube é que processos de destituição familiar correm em segredo de justiça, porque, uma vez decidido o rompimento de vínculo, a criança é proibida do contato com sua mãe.

O repasse de informações a Mercedes era um desafio à parte, tanto pelo intervalo quinzenal entre as visitas, únicos momentos quando tinha oportunidade de falar-lhe, quanto pela dificuldade de obtenção e entendimento das informações concernentes ao seu processo, que, por si, só demandavam um tempo que fugia ao meu controle. Por isso, tentava ser o mais objetivo possível durante nossas conversas, o que me foi facilitado pela sua própria compreensão dos trâmites jurídicos e biomédicos que lhe diziam respeito, o que me permitia aprender, com sua ajuda, muito do se passava sem ter que recorrer a outras fontes.

Assim, em meio aos repasses de algumas informações, Mercedes também me ajudava na compreensão de terminologias ou demais trâmites que, para mim, eram completa novidade. Não raro, por exemplo, me mostrava os extratos impressos da movimentação burocrática do seu processo penal, chamados “extratos da VEC” (Vara de Execução Criminal). Trata-se de uma síntese do caminho percorrido nas instâncias judiciárias pelo processo em questão, apontando as respectivas datas das entradas e saídas de determinadas instâncias judiciais e informando mudanças ou resultados de sua execução ${ }^{53}$. Os extratos da VEC podem ser obtidos diretamente do site do Tribunal de Justiça do Estado de São Paulo (TJ-SP), os quais, no caso de Mercedes, eram tanto acessados por mim quanto por ela mesma, mediante seu pedido ao setor de serviço social do HCTP.

À medida que fui me familiarizando com a dificuldade de seu caso, Mercedes também me confiou outras demandas que não se limitavam a buscar papeis, mas também a contatar sua família e ter notícias de seus outros filhos. Apesar de ter me dito que sua irmã já a visitara no HCTP algumas vezes e que mantinha troca de cartas com ela, Mercedes pedia-me que fizesse contatos telefônicos com sua mãe e irmã a partir das anotações, em meu caderninho, das perguntas que ela gostaria de fazer-lhes.

${ }^{53}$ Para um maior aprofundamento sobre os extratos da VEC, ver Godói (2015), cap 3. Nele, o autor tece uma rica reflexão sobre a gestão do tempo na dinâmica prisional, fazendo um paralelo com essa que era uma de suas funções na qualidade de agente pastoral, a saber, o levantamento e entrega dos extratos de VEC aos solicitantes. 
Tal tarefa não era muito diferente das demandas de outras pessoas custodiadas nos HCTPs. Na verdade, grande parte do meu trabalho enquanto agente pastoral se resumiu aos contatos familiares através do telefone. Porém, a fim de não atropelar o trabalho realizado pelo serviço social dos HCTPs, alguns contatos não eram por mim feitos diretamente, a fim de que pudéssemos contribuir com casos cuja competência já estivesse sob alçada desse setor e, assim, evitar o empreendimento de ações ou repasses de ditos que já fossem sabidos ou que simplesmente duplicassem o trabalho das profissionais de serviço social. No cotidiano de visitas, então, nós, membros do GT, costumávamos sair dos setores masculinos e femininos com nossos caderninhos cheios de anotação referente às demandas a nós dirigida e, em seguida, íamos para o setor de serviço social para conversar sobre situações que fossem compatíveis com a função que desempenhavam ali.

Alguns casos, devido à sua notoriedade, longevidade de internação ou recorrência de demandas, eram imediatamente reconhecidos pelas profissionais, dispensando a busca nos arquivos: "Ah, sei quem é...ligamos para o pai semana passada, disse que vem visitar mês que vem". Outros, no entanto, exigiam que déssemos nome completo, com sua respectiva matrícula, para que determinado prontuário (rosa para mulheres e verde para homens) fosse localizado. Primeiramente, o nome era buscado em uma tabela virtual que opera pela correspondência entre nome e código numérico do prontuário. Uma vez feita a correspondência, passa-se à busca física em grandes arquivos de metal para a averiguação das últimas providências tomadas, as quais são registradas em escrita pelas profissionais.

Entre o abrir e fechar de gavetas de uma de nossas incursões a essa pequena sala onde trabalham as duas profissionais de serviço social, esperei minha vez para conversar sobre o caso de Mercedes. Quando expliquei brevemente sua situação a uma das profissionais, embora ela soubesse de memória quem era Mercedes, foi preciso buscar seu prontuário rosa para que se lembrasse dos últimos acontecimentos.

Assim feito, vejo que ela lê a cópia de uma breve carta digitada pela profissional do serviço social do CDP Feminino e endereçada a Mercedes, unidade onde, como dito, ela estivera presa antes de sua transferência ao HCTP. Tal documento chegou às mãos de Mercedes quando ela ainda se encontrava naquela unidade penitenciária, o que me fez pensar que fora redigido antes da conversão de sua pena em medida de segurança. Nesse documento, cuja versão original a própria Mercedes havia guardado com ela e entregado 
a mim quando de um de nossos breves encontros de visita já no HCTP, estavam suscintamente redigidas algumas informações referentes aos seus filhos, com especial ênfase ao caso de Marcos. Tais informações escritas, correspondiam perfeitamente ao que Mercedes me explicara oralmente: seus outros filhos estavam sob a guarda da irmã, irmão e ex-marido, mas Marcos, que estava abrigado em SAICA, não podia mais ter contato com a família pois estava em processo de adoção. O interessante, porém, era que a redatora da carta, uma profissional de serviço social, relatava ter feito contato com outro profissional da mesma área, o qual trabalhava no Centro de Referência Especializado de Assistência Social (CREAS) da cidade natal de Mercedes e onde reside sua família. Como versa a carta, tal contato foi feito com o objetivo de obter informações sobre a situação jurídica dos laços familiares entre mãe e filho, ao que o profissional responde afirmando a impossibilidade de transmitir essa informação, salvo autorização judicial, uma vez que o processo corria em segredo de justiça. Por fim, a carta ressalta que o que resta ao CDP Feminino fazer era o acionamento do programa Mães do Cárcere mediante contato com a DP-SP.

Nesse dia, quando a profissional de serviço social do HCTP leu esse documento, eu tinha ciência de dois fatos. Em primeiro lugar, sabia que o CDP Feminino jamais fizera o contato com a DP-SP, uma vez que quando busquei acionar o programa Mães do Cárcere, em data posterior ao recebimento dessa carta por Mercedes, a defensora pública que me atendeu confirmou que Mercedes ainda não constava em sua lista. Em segundo lugar, àquela altura, tal estratégia já não era viável devido à conversão do regime de pena para medida de segurança.

Tais fatos me fizeram perceber como tentar penetrar a opacidade do Estado através da estratégia de levantar documentos ou do acionamento de órgãos estatais específicos não era um desafio exclusivo de agentes que não são funcionários do Estado. Em outras palavras, a dificuldade de obtenção de informações jurídicas e encaminhamento de possíveis ações, no caso em questão, não se deu sob uma chave de sociedade civil versus Estado. Ao contrário, esse trabalho pastoral, orientado pela linha do abolicionismo penal, envolvia uma tentativa de trabalhar em conjunto não só entre mim e Mercedes, mas no que ambos tentávamos acionar com agentes do Estado, a partir de telefonemas, troca de cartas ou levantamento de documentos. A incontingência imanente a esse trabalho e sobre a qual falava anteriormente também estava relacionada 
com a possibilidade de buscar parcerias, ainda que provisórias, com esses(as) funcionários(as).

Reitero, aqui, que a tentativa de trabalhar em conjunto não foi inaugurada por mim ou pelo GT. Mercedes, assim como outros(as) custodiados(as), também trabalhava por dentro, fazendo acionamentos possíveis com defensores públicos que, não obstante sua inconstância, também se faziam presentes dentro dos HCTPs para provisões jurídicas e esclarecimentos a pacientes-detentos(as). Também fazia contatos com outros setores, fosse o de educação, segurança, serviço social, psiquiatria, enfermagem, entre outros. Suas demandas não só se restringiam ao caso de seu filho, muito embora este fosse importante, e tampouco dependia de mim ou qualquer outro membro do GT para o andamento de seu cotidiano. A periodicidade quinzenal de visitas, em alguns casos, estabeleceu parcerias contingenciais para a solução de determinadas demandas, algumas das quais acabavam prescindindo totalmente de nossa atuação.

E, assim como essa busca de encaminhamentos às vezes resultava em obtenção de informações, era também preciso lidar, muitas vezes, com a falta delas. No que concerne à situação de Mercedes, por exemplo, vemos o obstáculo de comunicação, por conta do segredo de justiça do processo de Marcos, entre dois profissionais de assistência social, ambos funcionários públicos, cuja principal decorrência é o travamento de informações para uma terceira profissional da mesma categoria, esta última do HCTP em que Mercedes se encontrava custodiada, e quem, por sua vez, se comunicava comigo e com ela. Já na tentativa de acionamento da DP-SP, também uma instância estatal, vemos como uma mudança na natureza do processo penal - de pena para medida de segurança - outorgada por um juiz, que é, no exercício de suas funções, não um representante do Estado, qual se este existisse de modo reificado como um segundo plano que lhe é antecedente, mas o próprio Estado em ação, impossibilita a inclusão de seu nome para impetração de habeas corpus ou demais medidas jurídicas pelos defensores públicos que possibilitem penas alternativas à privação de liberdade. Afinal, como bem lembram Das e Poole, o Estado é "continuamente experenciado quanto desfeito através da ilegibilidade de suas próprias práticas, documentos e palavras" (Das e Poole, 2004:5, tradução minha).

O que gostaria de colocar em relevo, portanto, não é somente como o trabalho pastoral é mediado por diversos tipos de papeis, desde as anotações apressadas das palavras de Mercedes que fazia no meu caderninho, até seu repasse para o setor de serviço 
social ou à sua família. Mais do que simples mediadores, a busca pelos papeis do Estado talvez dê inteligibilidade para a paradoxal relação entre a fidelidade a uma linha penalabolicionista de ativismo e o quanto ela depende de acionamentos institucionais estatais, os quais, ao mesmo tempo que transgridem as fronteiras do HCTP, estabelecem um trabalho em conjunto na tentativa de encaminhamento de casos. No caso de Mercedes, esse trabalho contra o Estado envolvia a tentativa de construir pontes com a DP-SP ou com profissionais de serviço social, tal qual numa rede, cujos fluxos de escoamento ou interrupção de informação não se dão em lógica binária, numa chave sociedade civil versus Estado.

O que quero dizer com a impossibilidade de estabelecimento desse paralelo é o equívoco de justapor Estado à interrupção ou opacidade e sociedade civil ao escoamento de informações. Houve inúmeras vezes, por exemplo, que não dei a devolutiva de pedidos de Mercedes e de outros pacientes-detentos(as) por várias razões, fosse pelo seu não cumprimento devido à sobrecarga de demandas ou esquecimento, fosse pelo fato de não encontrar meu ou minha interlocutora na visita seguinte: porque estivesse ocupada, dormindo ou mesmo que tivesse sido desinternada no intervalo de tempo entre a solicitação e minha devolutiva, ou devido a uma impossibilidade de comparecer na visita subsequente, o que atrasaria a devolutiva em mais quinze dias. Em tais situações, antes que um polo de escoamento, acabei atravancando o fluxo de encaminhamentos. Da mesma forma, vi o engajamento de profissionais dos HCTPs, não só no caso de Mercedes, mas em vários outros para contatar familiares e acionar o Estado a fim de buscar uma solução às inúmeras demandas que eles também recebiam no exercício de suas funções, sendo sua atuação fundamental para o transcorrer dos eventos.

Essa rede de fluxos de informações e pessoas, além de conectar vários espaços para além do HCTP, evoca também uma consideração temporal subjacente à ideia de escoamento e travamento de informações. À conversão do regime temporalmente previsível da execução da pena para a imprevisibilidade da cessação de periculosidade, que segue em paralelo com a mudança de espaço, isto é, a transferência de um pavilhão comum em presídio para a ala psiquiátrica ou para um HCTP, somam-se outros fluxos temporais que seguem acoplados à dinâmica da "malha burocrática do Estado" (Relatório Hospitais-Prisão, 2018:47). 
No caso de Mercedes, a incerteza do processo anual de realização dos laudos psiquiátricos não vem dissociada da não menos incerta possibilidade de manter seu filho sob sua guarda, fato para o qual o manejo do tempo é essencial. Nesse sentido, não apenas deveria buscar contatos possíveis, como com a DP-SP, mas deveria fazê-lo com certa urgência, porquanto a possível adoção de Marcos estava em jogo. Concomitantemente, não deveria perder de vista outras demandas que me chegavam no curto período de tempo que permanecíamos nos HCTPs. Isso porque havia uma restrição de horários para as visitas, podendo ser iniciadas somente a partir das $9 \mathrm{~h} 00$ e com término obrigatório às $17 \mathrm{~h}$. Embora pareça um longo período, essa faixa de horário era dividida entre os dois HCTPs de Franco da Rocha, sendo o HCTP I visitado pela manhã e o HCTP II à tarde, cada qual com diferentes alas e, cada ala, com um número considerável de pacientes-detentos(as) o que tornava o fracionamento adequado do tempo uma tarefa tão essencial quanto dificultosa. Em relação ao manicômio judiciário de Taubaté, o problema não era menos grave uma vez que, embora fosse uma única unidade, sua área é extensa e sua localização distante. Por fim, o intervalo quinzenal entre uma visita e outra era o tempo disponível para dar conta das demandas que não eram encaminhadas ao corpo funcional durante as próprias visitas.

Uma das principais tarefas desse intervalo de quinze dias, além de contatos telefônicos com familiares, era a ida ao Fórum Criminal da Barra Funda de São Paulo, doravante chamado de Fórum Criminal, onde está localizado a $5^{\circ}$ Vara de Execuções Criminais (VEC) da Capital. Como dito no capítulo anterior, essa instituição era de particular interesse para o GT pois foi neste local onde, a partir de 2007, foram concentrados todos os processos de medida de segurança do Estado de São Paulo, antes espalhados por diversas VECs paulistas conforme região geográfica de ocorrência dos crimes (Barros, 2018:77). Sendo o processo de execução de Mercedes convertido de pena para medida de segurança, seu trânsito do CDP Feminino para o HCTP foi acompanhado pela transferência de seu processo de execução de uma VEC no interior do Estado de São Paulo para a $5^{\text {a }}$ VEC.

Decidi, então, ir ao Fórum Criminal para levantar o processo de Mercedes com o objetivo de melhor entender os fatos que a levaram presa e, posteriormente, custodiada. A razão principal para minha ida foi que, após a visita em que a profissional de serviço social leu a carta do serviço social do CDP Feminino endereçada a Mercedes para mim, entendi que não teria muito mais o que esse setor pudesse fazer no quesito destituição do 
poder familiar. A natureza do caso havia extrapolado para uma área exclusivamente jurídica, externa à alçada do serviço social.

A importância de buscar os processos de execução consiste no fato de que esses são tomos documentais, alguns extremamente extensos como vimos no caso de Daiana, nos quais estão arquivadas todas as informações e principais documentos referentes ao andamento de um processo - desde o inquérito, passando pela sentença, até os trâmites e ocorrências da fase de sua execução, ou seja, período do cumprimento da sentença, cuja competência recai sobre o juiz de execução. Devido à sua concentração numa única VEC, todos os processos de medida de segurança em âmbito estadual estão subordinados a um único juiz.

Se o manejo do tempo é um desafio durante as visitas, não menos desafiante é manejá-lo nas incursões ao Fórum Criminal. Assim como nos HCTPS, a entrada aos interiores do fórum está condicionada pela passagem dos corpos através dos detectores de metais e dos pertences por um equipamento de raio $\mathrm{X}$, semelhante aos que se encontram em aeroportos. Como consequência dessa revista individual a todos(as) que entram, forma-se uma longa fila de não-funcionários do fórum em sua entrada principal, à qual, enquanto membros do GT, somos obrigados tomar lugar.

Uma vez submetidos(as) à revista e autorizados a entrar, subimos a rampa em direção ao primeiro andar e percorremos longos corredores labirínticos com destino ao

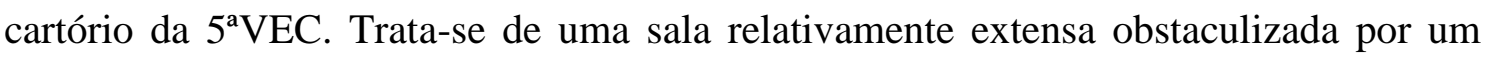
balcão logo à entrada. Ele separa o perímetro onde trabalham os funcionários, rodeados por longas estantes onde se espremem incontáveis processos, e o pequeno espaço dos solicitantes.

Para o caso de Mercedes, então, repeti o procedimento que já fizera com demandas anteriores. Disponibilizei seu nome completo, bem como seu número de RG ao funcionário competente, que, lançando esses dados num sistema virtual, fez a correspondência entre eles e a localização física de seu processo de execução, método não muito diferente ao que havia testemunhado no setor de serviço social do HCTP. Uma vez localizado, ele é colocado em cima do balcão para que o folheemos.

Como não podemos retirá-los do espaço físico do cartório, nosso momento particular com os papeis pode ter dois formatos: para o caso de busca de informações 
mais pontuais, basta procurar documentos específicos e anotar o que está grafado em nossos caderninhos, a fim de repassar os dados aos nossos interlocutores. Já para um entendimento de seu conteúdo como um todo, tal como era a situação de Mercedes e como tentei fazer com o processo de Daiana, é preciso que se fotografe, página a página, a fim de se obter uma cópia em sua íntegra. Portanto, além do tempo de espera na fila de entrada, era preciso considerar as horas durante as quais ficaríamos em pé defronte ao balcão, fotografando individualmente as laudas de processos que poderiam ultrapassar duzentas páginas de conteúdo. Se a foto está fora de foco ou mal ajustada para a visibilidade dos escritos, é preciso paciência para repetir a mesma página tantas vezes que forem necessárias até uma possível legibilidade.

Feitas as fotografias do processo de Mercedes, passei à leitura de seus dizeres. Foge das minhas intenções reproduzir de modo completo o que as inúmeras páginas jurídicas versam. Minha intenção é, antes, destacar modos como alguns fatos são narrados, ou, melhor dizendo, como eles contam histórias em "enredos de condenações" (Nelvo, 2017), e em que medida atentar para o que os documentos temporalizam em seus dizeres é relevante para o trabalho pastoral na busca de "um mundo sem cárceres".

\section{A história espiralar do "tudo teve início"}

"Tudo teve início porque a ré, genitora de criança, viu a filha [nome da criança] ser confiado á guarda de parente próximo (tio, testemunha [nome do parente], irmão da ré)" (sic, trecho da sentença).

Aos olhos do juiz, a história de Mercedes tem um início. Um início que é repetido exaustivamente ao longo de seu processo. Sua "história" começa com uma folha inicial, intitulada “GUIA DE INTERNAMENTO - MEDIDA DE SEGURANÇA” em que constam seus dados pessoais com categorias pautadas pelo masculino universal. No cabeçalho, por exemplo, lê-se NOME DO PACIENTE e, na categoria profissão, lê-se desempregado (ênfases minhas).

Um pouco mais abaixo, a seção DADOS DO PROCESSO CRIMINAL oferece uma síntese com as principais datas de andamento do processo, desde a denúncia pelo Ministério Público do Estado de São Paulo (MP-SP), até a publicação da sentença. Nessa seção consta, também, a categoria "tipificação penal”, na qual estão arrolados, em negrito, os artigos do Código Penal (CP) infringidos e que reproduzo abaixo: 
Art 138 "caput" (diversas vezes) c/c Art. 141 "caput", II c/c Art. 145 "único" e Art. 339 "caput” (três vezes) e Art. 147 “caput" e Art.339 "caput" (três vezes) e Art. 344 todos do(a) CP (fls.1)

Por fim, estão grafados, respectivamente, o prazo mínimo de internação (dois anos) e os nomes dos defensores públicos atuantes em defesa de Mercedes. Nota-se, assim, como se mostra importante não somente documentar quais artigos do CP Mercedes é considerada infratora, como também o número de vezes que isso ocorreu. Nas páginas subsequentes, seguem os autos do processo na ordem de andamento de um processo penal, a saber: inquérito policial, indiciamento do MP-SP e a sentença exarada pelo juiz.

O inquérito, então, é a primeiro momento de fato dissertativo no qual uma certa história é contada. Não cabe, aqui, discorrer de modo pormenorizado seu conteúdo na medida em que me interessa menos a história em si do que a maneira através da qual Mercedes é construída pelas palavras oficiais. O texto, assinado pelo delegado de polícia e pelo escrivão, abre com o relato de "denúncias caluniosas" contra o promotor de justiça que veio a responder pela Vara de Infância e Juventude atuante no caso de uma das filhas de Mercedes, a qual, diferentemente de Marcos que foi encaminhado para SAICA, ficou sob a guarda de seu irmão, tio da criança. Segundo o documento, ocorre que, após a audiência em que teria ficado decidida a guarda para o irmão de Mercedes, esta teria reconsiderado e entrado com uma ação para reaver a guarda de sua filha, ao passo que ele, em reação, entrou com ação para a manutenção da guarda. Durante o trâmite do processo na vara competente, então, Mercedes teria empreendido uma sucessão de "denúncias caluniosas e difamatórias" por ela realizadas de forma escrita e verbal tanto pessoalmente quanto através do canal de denúncias "disque 100" contra diversos atores envolvidos no caso em questão, quais sejam, seu irmão, um promotor de justiça e dois conselheiros tutelares (inquérito, fls 3). O texto afirma, ainda, que Mercedes teria agido com dolo pois sabia de antemão serem falsas as acusações que fazia contra esses agentes.

É interessante notar que o texto é escrito inteiramente em terceira pessoa com emprego do discurso indireto, salvo uma única frase, colocada como citação das palavras de Mercedes com o uso de aspas, a qual o delegado utiliza para sustentar a argumentação do crime de coação, devido ao seu teor considerado ofensivo. Em conclusão, a última frase do inquérito, que inicia com "Isto posto”, sugere um elo entre os eventos narrados e a tipificação legal, enquadrando-os nos crimes de "ameaça, calúnia, difamação, denunciação caluniosa e coação" (ibid). 
A seção seguinte é o indiciamento do MP-SP, que é endereçado ao juiz competente e assinado pela promotora de justiça atuante no caso de Mercedes, lembrando que o promotor referido anteriormente é, nesse processo, designado como vítima das acusações de Mercedes.

A estrutura do indiciamento, por sua vez, compreende um cabeçalho com o brasão do MP-SP à esquerda e os seguintes dizeres como cabeçalho: "MINISTÉRIO PÚBLICO DO ESTADO DE SÃO PAULO - EXCELENTÍSSIMO(A) SENHOR(A) DOUTOR(A) JUIZ(A) DE DIREITO DA [nome da vara e comarca]". A seguir, tem-se o número de identificação dos autos do processo e o início do texto, que segue, na primeira parte, uma estrutura de nove tópicos, respeitando uma regularidade sintática e semântica que os uniformiza. Cada qual respeita, em ordem, o seguinte padrão: inicia com a frase "Consta nos autos...."; especifica, respectivamente, data, hora e local da situação a ser narrada; destaca, em caixa alta, negrito e sublinhado o nome completo de Mercedes; utiliza, a partir de referenciamento no inquérito, a frase "com dados qualificativos a fls [número da folha]"; narra uma situação específica cuja autoria é atribuída a ela e que fora mencionada no inquérito.

A segunda parte do indiciamento segue um formato dissertativo e em discurso indireto, mantendo o nome de Mercedes na formatação de texto mencionada e, vez ou outra, substituindo seu nome por apostos como "genitora" ou "denunciada". No que diz respeito ao conteúdo, são recontadas as situações elencadas nos tópicos anteriores que, por sua vez, são repetições daquelas apresentadas no inquérito. Temos, ao final de cada narração, uma conclusão em negrito do crime a que corresponde cada atitude ou comportamento de Mercedes. Nota-se que, novamente, para caracterizar o crime de "coação", a mesma frase em discurso direto presente no inquérito, alegadamente proferida por Mercedes, é citada como prova.

Finalmente, o documento termina com "diante do exposto denuncio [nome completo de Mercedes em caixa alta, negrito e sublinhado] como incursa:". A seguir, são arrolados, também em negrito, os artigos penais considerados infringidos, os mesmos da primeira folha do tomo, especificando o número de vezes que os cometeu e contra quais atores, estes designados como vítimas, os fez. Encerra com a lista de nomes completos das pessoas envolvidas com a categoria "vítima" grafada ao lado de cada nome. 
Após uma sequência de documentos burocráticos de menor monta, bem como de sua folha de antecedentes criminais, temos a sentença de Mercedes. No cabeçalho, vemos à esquerda, o brasão do Tribunal de Justiça de São Paulo, acompanhado do título "SENTENÇA" em negrito. Abaixo, entre outros dados, temos a categoria "autor" para designar "Justiça Pública" e "réu” para o nome completo de Mercedes. Novamente, então, o texto abre com seu nome completo em caixa alta, negrito e sublinhado atribuindolhe a infringência aos mesmos artigos penais, bem como o número de vezes de infração, tal como consta nos documentos anteriores. Em sequência, recoloca os fatos narrados no inquérito e no indiciamento pelo MP-SP, de modo inteiramente dissertativo. Tal narração segue sustentando-se na referência a esses documentos oficiais, especificando as páginas que os embasam enquanto "fatos". Além disso, coloca outra camada de legitimidade ao afirmar que os acontecimentos condizem com os relatos de vítimas e testemunhas, bem como com os registros de provas documentais, as quais ultrapassam duzentas páginas (sentença, fls.40).

O juiz, então, faz uma síntese do que requer a acusação, isto é, o MP-SP, em relação à ré, ressaltando que Mercedes recusou-se, por duas vezes quando presa preventivamente, a comparecer em audiências de instrução e interrogatório. Ainda em referência à peça da acusação, o juiz destaca que a ré teve intencionalidade em todas as condutas e que "A ré se mostrou indiferente ao processo". Escreve também que a acusação "Destaca a prova oral e o silêncio da ré" (ibid). Depois, dedica dois breves parágrafos ao que requer a defesa, a qual mobiliza dois argumentos para o pedido de sua absolvição: (i) de que Mercedes "seria semi-imputável, sem consciência do caráter criminoso da conduta”, demandando internação em alternativa à reclusão, no caso de condenação; (ii) de que haveria possibilidade de arrependimento dos seus atos, caracterizando um importante atenuante que deveria ser levado em consideração (ibid).

A essa reprodução de argumentos da acusação e defesa, segue a decisão do juiz, que é separada do texto apresentado até aqui da seguinte maneira: "é o relatório. DECIDO”, em negrito (ibid). Declara, então, que a denúncia é procedente e o fato de Mercedes ter se ausentado nas audiências é caracterizado como uma conduta "indigna" de sua parte, o que, no entanto, não compromete o que o juiz denomina de "contexto probatório" (ibid). 
Retomo, então, a citação que fiz como abertura à presente seção, em que proponho discutir o processo de Mercedes. Embora a frase não esteja localizada no seu início, mas como parte do texto que compõe a sentença, acredito que seja paradigmática por delimitar um início oficial, um ponto a partir do qual todos os eventos parecem derivar sua razão de ser:

"Tudo teve início porque a ré, genitora de criança, viu a filha [nome da criança] ser confiado á guarda de parente próximo (tio, testemunha [nome do parente], irmão da ré)" (sic, sentença, fls.41).

Tal frase é também uma demarcação para o começo de uma nova repetição dos eventos registrados nos autos que descrevi até agora, fazendo-lhes referência, com número de página, quando conveniente, para embasar afirmações.

É interessante notar, contudo, que, se os eventos são recontados seguindo o referenciamento a outros documentos, assim como o fazem o inquérito, indiciamento e a própria sentença, produzindo o efeito de coerência e legitimidade entre os papeis oficiais e a veracidade dos fatos narrados, eles não dispensam o uso de categorias morais e julgamentos de valor na construção da culpabilidade de Mercedes. Seguindo a narrativa da sentença, chama a atenção que, ao mencionar a situação de insulto ao promotor de justiça atuante no caso da guarda de sua filha, o juiz escreve que a conduta do promotor ao denegar-lhe a guarda não era atitude "graciosa, mas motivada por dever de oficio". Já a reação de Mercedes à denegação, ameaçando-o “por palavras”, é caracterizada como fruto da "inconformidade da ré" ao dever do promotor de proteger a criança de "risco palpável”, caso esta permanecesse sob sua guarda. Também aqui vemos a passagem ao discurso direto para citar, novamente, a frase supostamente proferida por Mercedes que a colocou como autora do crime de coação. Acrescenta, ainda, que ela "teve a audácia de contatá-lo por carta, também com fins de ameaça e referencia essa afirmação com uma das páginas do inquérito (ibid, fls.41-44).

Quando se dirige ao crime contra os conselheiros tutelares, designa-os como "igualmente alvos da fúria da ré” para, em sequência, reiterar a ausência de Mercedes nas audiências judiciais com o seguinte parágrafo:

Repise-se que a ré pouco ou nada se interessou pelo desfecho da ação penal e a apuração dos fatos, quedando-se inerte no inquérito e, em Juízo, recusando-se a comparecer para a instrução e interrogatório. (...) Assim, verifica-se que prova 
alguma trouxe no inquérito, onde ao menos compareceu para prestar suas declarações; recusou-se a assinar o mandado de citação ou a constituir defensor para sua defesa. E se fez revel, dando ao processo criminal contra ela instaurado pouca ou nenhuma valia (ibid, fls. 44-45, ênfase minha).

Além das próprias repetições dos fatos narrados, a expressão “repise-se”, permitenos inferir que dentre todos os eventos e situações, alguns parecem adquirir maior gravidade porque introduzidos por expressões enfáticas, como o alegado desinteresse de Mercedes pelo desdobramento do processo.

Após uma sequência de citações de autores juristas que discutem o conceito de "honra" para o Direito, estas devidamente referenciadas e destacadas em negrito, o juiz continua:

\begin{abstract}
A ré, agindo como agiu, não buscou outro resultado senão o de menoscabar e ofender as honras das vítimas individualizadas na denúncia, ao que consta, excetuado o irmão, pessoas a quem sequer conhecia anteriormente.

(...) Em se tratando de crime praticado mediante escrita, meditada e endereçada a autoridades, com oportunidades sucessivas de a ré comprovar e justificar as acusações, descabe falar que a ré agiu em momento de destempero ocasional.

(...) Observo que a ré, segundo incidente de insanidade mental, padece de comprometimento mental de entendimento parcial de entendimento (semi-imputável), aconselhando, aos olhos do experto, internação pela renitência em, espontaneamente, tratar seu mal. A lei, porém, faculta a substituição da pena privativa de liberdade para esse fim (artigo 98 do Código Penal), o que importa compreender que é mister, antes, a fixação da pena privativa de liberdade (ibid, fls.46-48).
\end{abstract}

$\mathrm{Na}$ parte final da sentença o juiz passa à estipulação das penas, colocando em relevo, de saída, que Mercedes tem "maus antecedentes criminais", cujo documento encontra-se anexado no processo anteriormente à sentença, o que lhe serve de base para o aumento da pena para cada crime citado no processo em um sexto. Adiante, depois de repetir os artigos penais infringidos seguidos do tempo de pena a ser cumprido, o juiz reforça que sua recusa de comparecimento às audiências, adjetivando Mercedes como "indiferente", é evidência, junto ao laudo de incidente de insanidade mental, que sua “conduta é mesmo distorcida, (...)sem compreensão exata do que praticou”.

Como mais uma de suas referências, o juiz passa a citar excertos, apresentados em itálico, do incidente de insanidade mental, um dos quais atesta que Mercedes tem "sinais, história e sintomas compatíveis com moléstia mental parcialmente
alienante"(ênfase minha) condizente com uma das enfermidades elencadas na 
Classificação Internacional de Doenças e de Problemas Relacionados a Saúde (CID), a saber, "Transtorno com personalidade emocionalmente instável (CID F 60.3), acrescentando que detém "inteligência limitrofe" (incidente de insanidade mental, fls.92 apud sentença, fls. 49). E, devido à "crítica de sua moléstia”, isto é, devido à sua resistência ao diagnóstico durante a realização do exame pelo perito psiquiátrico, bem como à apresentação de "sinais de irritabilidade e impulsividade" e ausência de "respaldo familiar", o juiz considera "urgente" a internação em HTCP em detrimento de tratamento ambulatorial. Na condição de alguém que se apresenta como um "risco social", seu transtorno mental não deve ser atenuante que justifique redução de pena, mas conversão desta em internação, ressaltando que não seria um equívoco inferir que Mercedes representa uma ameaça não só a si mesma, como ao entorno social e à sua filha, "mote de todo o processo" (sentença, fls.49-51).

Por fim, o juiz inicia a exaração da pena para cada crime cometido, ressaltando novamente o número de vezes que cada artigo do $\mathrm{CP}$ foi infringido, reiterando, ainda, por duas vezes, que não se trata de exaração direta de medida de segurança, mas da conversão de pena para medida de segurança, uma vez que é considerada semi-imputável. No texto, o início da redação concernente às penas, uma para cada artigo infringido, é inaugurado pela expressão "Pelo exposto" seguido de “JULGO PROCEDENTE, EM PARTE, a ação penal que a JUSTIÇA PÚBLICA promoveu contra [NOME COMPLETO DE MERCEDES]" (ibid, fls.50). Ressalto que as palavras em caixa alta também estão em negrito. $\mathrm{O}$ documento termina com o nome completo do juiz e assinatura, seguidos de local e data de sua publicação.

Minha preocupação de colocar em relevo não apenas sobre o que os autos versam, mas descrever em que formatação as situações narradas se encaixam deve-se ao fato de que a forma é tão importante quanto o conteúdo dos papeis. A respeito da relevância do formato para produção de legitimidade, Catarina Morawska (2014) promove uma interessante análise a partir de uma etnografia dos documentos envolvidos na construção de grandes empreendimentos hidrelétricos no Brasil e que, não obstante a diferença de temáticas, permite tecer alguns paralelos com os documentos referentes a Mercedes. Ao seguir pelo que chama de "trilha de papeis", a autora identifica que a confecção de documentos respeita tanto uma sequência predeterminada quanto um referenciamento mútuo. É por isso que os entende como observantes de uma certa "estética", na qual os documentos se relacionam como "vinculantes e vinculados entre si" (Morawska, 
2014:30). Vinculantes porque a produção de um documento é precondição para a confecção dos que o sucedem, da mesma forma que, no caso de Mercedes, o inquérito produzido pelo delegado de polícia é primeiro critério para que o indiciamento e, posteriormente, a sentença ganhem existência. São vinculados pois, a despeito das diferentes competências dos órgãos envolvidos nos empreendimentos hidrelétricos, os conteúdos documentais não se dão isoladamente, mas se sobrepõem através de referências várias entre si. Tal sobreposição é semelhante à repetição de eventos que observei nos papeis de Mercedes, a qual (re)inscreve e (re)organiza a gravidade de seus atos estabelecendo conexão com conteúdos de alhures.

Um segundo ponto analisado por Morawska é o modo pelo qual saberes técnicocientíficos inscritos nos papeis operam um "efeito de realidade" e, assim, legitimam essas obras de engenharia. Tal efeito, entretanto, é derivado menos de seu conteúdo do que pela sua forma uma vez que é o próprio respeito ao ritual de sequência e referenciamento de peças documentais a fonte de "exterioridade e objetividade", a qual, a uma só vez, "despolitiza" e torna imprescindível a construção das hidrelétricas (ibid:34). Isso permite que a autora desloque o foco em termos binários, isto é, a conclamação do domínio social em oposição ao econômico, para como argumentos de cunho social e ambiental das forças opositoras, seja de instituições militantes ou populações afetadas por essas obras, são incorporados e neutralizados por meio dos cálculos ratificados por esses documentos.

Analogamente à despolitização que os saberes técnico-administrativos impõem ao processo de construção de hidrelétricas, acredito que o enfoque proposto por Morawska seja rentável para entender como categorias morais não se fazem em oposição ao discurso jurídico mobilizado nos autos de Mercedes, mas valendo-se, justamente, da inserção de uma moralidade referenciada juridicamente a fim de chancelar sua condenação, bem como sua moléstia mental.

A moralização presente na gramática jurídica é também o foco de Laura Moutinho (2004) em sua análise sobre conjugalidades interraciais no contexto do Apartheid sulafricano, na qual os processos criminais são seu material etnográfico. Um dos pontos centrais que denota a relação entre moral e Direito e colocado sob escrutínio pela autora é a legislação que interditou os relacionamentos heteroafetivos interraciais, nomeadamente, os atos Immorality Act (1927) e o Prohibition of Mixed Marriages Act (1949), os quais têm como mote o pressuposto de que o intercurso sexual seria forma de 
“poluir” a raça africâner, julgada como superior às demais (Moutinho, 2004a:350). Seu enfoque é valioso por não obliterar "a margem de manobra permitida pela lei que os atores (réus, testemunhas e acusados) possuíam", frente a uma legislação que construía sujeitos racializados a partir de noções, incorporadas à letra da lei, de virilidade do "homem "negro"” e "pureza da mulher 'branca"” (Moutinho, 2004b:386).

Como paradigmático dessa "margem de manobra", a autora toma como base um dos processos criminais analisados em que se julgava o relacionamento afetivo entre uma mulher enquadrada como de "aparência europeia e viúva", porém autodeclarada "non european" com um homem considerado "coloured". A fim de que fosse oficialmente reclassificada em termos raciais, a ré mobiliza, a seu favor, elementos como "origem", "descendência", "pertencimento" e "aceitação" do grupo racial ao qual julga pertencer, estratégia essa que acaba por ser bem-sucedida ao mobilizar variáveis que sobrepujaram sua cor e seu casamento é, enfim, autorizado (Ibid:398).

O paralelo que proponho com a linguagem do processo penal de Mercedes é em seu semelhante teor moral inscrito na gramática legal, sobretudo em dois aspectos: (i) categorias adjetivas marcadamente morais são mobilizadas a fim de construí-la como imprópria para as funções maternais, sendo, tal como o fazem as normativas de casamentos interraciais, um exemplo de como o Direito incide nas relações afetivas, gerindo-as; (ii) na equiparação de sua "história" com os sintomas de um distúrbio mental, evocando uma temporalização das categorias biomédicas, isto é, como se essa "história" fosse ferramenta de uma noção de sintoma. De modo análogo, segundo Moutinho (2004b), o pertencimento racial é construído pela mobilização de categorias que remetem a um contexto sócio temporal de descendência e pertencimento, mostrando como essa categoria transcende uma noção fechada na ideia de cor, simplesmente.

A interface entre moral e Direito é notória sobretudo em uma das partes da sentença de Mercedes, na qual o Juiz lança duas definições de "honra", cunhadas por juristas, a fim de conceituar o que ela violou quando proferiu e escreveu palavras "difamatórias". Reproduzo, abaixo, o excerto no qual a citação de um dos juristas pelo juiz aparece em negrito:

Ensina Cléber Masson, respaldando o sentimento já enfatizado pelas vítimas em declaração judicial:

"Honra é o conjunto das qualidades físicas, morais e intelectuais de um ser humano, que o fazem merecedor de 
respeito no meio social e promovem sua autoestima. É um sentimento natural, inerente a todo homem e cuja ofensa produz uma dor psíquica, um abalo moral, acompanhados de atos de repulsão ao ofensor. Representa o valor social do indivíduo, pois está ligada à sua aceitação ou aversão do outro dentro de um dos círculos sociais em que vive, integrando seu patrimônio. Trata-se de patrimônio moral que encontra proteção como direito fundamental do homem no art. $5^{\circ}$, inciso X, da Constituição Federal (fundamento constitucional dos crimes contra a honra". (Código Penal Comentado, 2014, pág.642 apud sentença, fls.46).

O "efeito de realidade", valendo-me da expressão de Morawska (2014), pode ser observado sob um duplo prisma. Em primeiro lugar, temos a naturalização de um atributo, qual seja, a "honra", axiomático à condição de "homem”, palavra que evoca uma conotação de gênero para equivaler à condição humana. Tal atributo é estabilizado em termos de "sentimento", tanto pelo emprego dessa palavra logo anterior à citação, que orienta a leitura subsequente, quanto pelo seu uso no próprio corpo do texto citado, enquanto "sentimento natural". A carga sentimental é reforçada pela afirmação de que sua ofensa ocasiona "dor psíquica”, "abalo moral” e "atos de repulsão ao ofensor".

Em segundo lugar, no que concerne ao seu aspecto "vinculado", é possível notar conexões semânticas com outros referenciais. Nesse sentido, não é fortuito que o juiz introduza a citação como um respaldo ao que as vítimas previamente relataram, assim como não o é por escolher um excerto que estabelece o elo entre os eventos narrados e a corrupção da "honra" de outrem. Essa conexão, que opera por conceitualizar atitudes e comportamentos de Mercedes como ofensas à "honra" contra representantes do Estado, ganha status ainda maior de inerência ao se referenciar numa obra jurídica, a qual, por sua vez, se referencia na Constituição Federal, por esta definir "honra" como um "patrimônio moral” protegido.

A moralidade, no entanto, não está restrita à citação. As expressões empregadas para caracterizar atitudes e comportamentos de Mercedes ao longo de praticamente todo processo são atravessadas por valorações morais, mobilizando suas palavras e silêncios como elementos probatórios de uma personalidade perigosa. Desde o inquérito, vemos como as palavras escritas e proferidas por Mercedes são enquadradas na linguagem da lei para serem conceituadas como crimes contra a honra das vítimas, através das tipificações penais de "ameaça, calúnia, difamação, denunciação caluniosa e coação". Esse enquadramento mobiliza cargas emotivas para designar as palavras de Mercedes quando, por exemplo, atesta que os conselheiros tutelares foram "alvos da fúria da ré". Por outro 
lado, nos momentos em que os documentos atentam para as ausências de Mercedes nas audiências judiciais e no interrogatório, "o silêncio da ré" é tanto prova de sua postura "indiferente" ao processo, quanto de sua enfermidade mental, sobretudo quando o juiz afirma que, referindo-se à recusa de comparecimento, a "conduta é mesmo distorcida, (...) sem compreensão exata do que praticou”.

Além disso, ao mesmo tempo que moraliza, o texto lança mão de referenciamentos aos documentos probatórios, exaustivamente repetidos, e não dispensa a referência direta do que Mercedes teria verbalizado como ameaça. Nesse sentido, a "estética" dos papeis, no meu caso, é evidente não somente pelos vínculos entre documentos, mas igualmente pelas passagens de discurso indireto para direto, as informações em caixa alta e/ou negrito e o emprego de expressões categóricas - "é $o$ relatório" ou "DECIDO".

O processo de fabricação de "materialidade, estabilidade e oficialidade" através de documentos é também o cerne do trabalho de Larissa Nadai (2016) em etnografia dos inquéritos policiais numa delegacia de defesa da mulher (DDM). Perscrutando o trabalho das escreventes, balizado fundamentalmente por práticas de escuta e registro, a antropóloga atenta para a produção dos fatos e a instauração da verdade dos eventos. Nessa fabricação, são essenciais as insígnias de oficialidade, como assinaturas e carimbos, capazes de auferir uma "dimensão simbólica", transformando papel em documento (Nadai, 2016:72).

No que concerne aos inquéritos redigidos, a antropóloga observa processos de “identificação" e "contraidentificação" operados em relação à vítima e ao agressor, os quais não passam imunes ao produto final dos documentos. Além disso, são mobilizadas categorias morais de "família", "pobreza" e "desestruturação" que ganham inteligibilidade justamente por causa e não a despeito da subjetividade que acompanha o cotidiano desse trabalho. Nessa "economia textual", a depender do interlocutor em contato com a escrevente, a impessoalidade da terceira pessoa transforma-se em certa cumplicidade, sobretudo quando se transita da terceira para a primeira pessoa da vítima (ibid:84).

Não muito diferente disso é o que pode ser observado nos autos de Mercedes. Como tentei mostrar, grande parte dessa "economia textual" é estruturada por repetições da narração dos fatos e estruturas sintáticas que conformam uma certa "estética" a partir 
da qual ela é reinserida exaustivamente em paralelo com os eventos, a fim de contextualizá-la como autora de atos entendidos como crimes. Para isso, não é fortuita a repetição dos eventos em correspondência com os artigos do Código Penal supostamente infringidos, dando um significado jurídico aos discursos e silêncios de Mercedes. Como elemento probatório, a fala caluniosa de Mercedes ao promotor é colocada em discurso direto, mas não como um processo de "identificação" como vemos no trabalho de Nadai, mas talvez mais próximo da "contraidentificação", justamente como elemento probatório de seu crime e seu destempero emocional. ${ }^{54}$ Seu silêncio e ausência nas audiências judiciais são igualmente investidos de significado a fim de patologizá-la como infratora da honra das vítimas e enquadrá-la como semi-imputável.

Nessa estratégia patologizante a categoria "história" presente na sentença deixa pistas para a construção dessa narrativa, falando tanto sobre quanto para além de seu conteúdo repetitivo. Fica claro que, longe de falhas textuais ou mero protocolo retórico, as exaustivas repetições dos eventos criminalizados e patologizados por diferentes documentos (inquérito, indiciamento, sentença, incidente de insanidade mental) em suas mútuas referências e citações, são produto da interface entre saberes médicos e jurídicos que operam a partir de uma temporalidade de reatualização, isto é, não obstante referenciada num passado materializado por datas e emprego de verbos no pretérito como revestimento de concretude a eventos, situações e (não)ditos, existe a reiterada inferência da probabilidade de sua reincidência, sobretudo por ter-se como pressuposto sua moléstia mental. A referência a seu histórico criminal, por exemplo, é a base sobre a qual a legitimidade de aumento das penas em um sexto se sustenta, ou seja, eventos passados ocasionam acréscimos de tempo no futuro e acabam por reiterar a periculosidade do enredo de sua "história”, para que lhe seja devidamente provido o desfecho que se julga correto.

Com efeito, relevantes trabalhos etnográficos que se debruçam sobre documentos chamam atenção para a construção do passado a fim de positiva-lo material e temporalmente. Roberto Efrem (2017) é bastante elucidativo a esse respeito ao analisar o assassinato brutal da jovem Emília. Seu homicídio poderia ser duplamente

\footnotetext{
${ }^{54}$ Mais de uma vez, podemos ver o emprego de frases que caracterizam Mercedes como portadora de transtorno mental. Cito como exemplo um trecho de seu exame de cessação de periculosidade: "Há $a$ informação de que quando ela soube que sua filha não ficaria sob sua guarda, ela surtou (exame de cessação de periculosidade, fls.80, grifo meu).
} 
"dimensionado", isto é, separado entre o ato em si e a narrativa posterior que sobre ele se faz através de documentos. Entretanto, o autor é preciso em sua análise quanto ao entendimento de que "a primeira dimensão só existe através da segunda. Uma não precede a outra. Dialeticamente fazem-se" (Efrem, 2017:n.p.). Seu ponto, portanto, é que a violência não é autoevidente per se, e a irrecuperabilidade do fato tal como transcorreu é o que enseja o assassinato como um campo de disputa entre distintas narrativas a fim de que a brutalidade possa ser visibilizada sob determinado ângulo.

Na mesma linha, Juliana Farias (2015), em artigo sobre as execuções sumárias perpetradas por policiais no Morro do Russo, no Rio de Janeiro, percebe a indissociabilidade entre o "fuzil" e a "caneta". Assim como no texto de Roberto Efrem, a autora não vê a produção do laudo cadavérico como mero registro a posteriori do homicídio, mas como uma "economia de palavras" que instaura oficialmente o ocorrido sob revestimento do poder estatal por suas "práticas de escrita". Sua análise é de grande valia por atentar não só para o que se escreve nos documentos oficiais, mas para aquilo que se deixou eclipsado, na chave de "ilegibilidade" sob a qual opera o Estado (Farias, 2015:87). Dialogando diretamente com Veena Das e Deborah Poole (2004), Farias recupera esse conceito precisando que o "ilegível” não é necessariamente o que é indecifrável em sentido estrito, mas aquilo que opera por uma seletividade do que resulta visibilizado e do que é rejeitado a partir da oficialização da informação legítima e verdadeira.

Cotejando essas análises com o caso de Mercedes, vejo que elas iluminam o desafio de investigar a temporalidade dos papeis e como estes perfazem "fatos" a partir de um exercício de poder, do qual os documentos não são ferramentas de anotação, mas mecanismo essencial da punição que lhe é impingida. Através dessa "economia de palavras", os autos reiteradamente constroem as situações que incriminam Mercedes não somente a partir do que supostamente fez, mas de suas atitudes para com o decorrer do processo judicial. A citação de sua fala em primeira pessoa é reconduzida inúmeras vezes, englobada por um discurso oficial em que sua voz jamais aparece senão a partir do que supostamente proferiu de forma injuriosa. Sua sentença consolida uma "história", da qual ela é menos protagonista do que refém, e cujo enredo, além de ser correspondente com uma patologia psiquiátrica, em referência ao incidente de insanidade mental como estratégia probatória, parece seguir um movimento espiralar de várias reconduções semânticas, as quais, a despeito das reiterações, progridem temporal e semanticamente 
em direção ao fim aparentemente natural e esperado: o manicômio judiciário. Fim esse que, ironicamente, não tem término definido uma vez que, como dito, a medida de segurança não dispõe de prazo máximo.

\section{Abolicionismo penal como recusa do "tudo teve início": o que nos dizem os}

\section{bebês na cachoeira?}

Pouco tempo depois de minha ida ao Fórum Criminal para fotografar o processo de Mercedes, liguei para a sua família conforme ela me pedira na visita anterior para saber notícias dos seus. Contatei sua irmã e, depois de me apresentar e explicar o motivo de minha ligação, passei a anotar em cor diferente da anotação das demandas de Mercedes que havia feito em meu caderninho para distingui-las das devolutivas que recebia naquele momento ao telefone. Esse contraste de cor me facilitaria no momento de lê-las na visita seguinte para ela. Após me dizer que seus filhos estavam bem, inclusive a menina que estava sob a guarda de seu irmão, ela me disse que, dias antes, recebera a notícia através de uma funcionária de serviço social que Marcos fora adotado por uma família e que Mercedes já estava ciente pois havia telefonado para a funcionária de serviço social do HCTP, a mesma que eu havia conversado sobre seu caso de destituição do poder familiar, pedindo a ela que transmitisse a notícia a Mercedes.

Nas visitas que se sucederam, ainda mantive uma interlocução com Mercedes, embora fosse menos frequente. Alguns de nossos encontros limitavam-se a um cumprimento; em outros, conseguia engatilhar algumas conversas menos fugazes a respeito do cotidiano da ala ou das demandas de contato com sua família. Além de mim, Mercedes conversava com outra agente pastoral, também membra do GT, que, assim como eu, estava ciente do seu caso. Em nenhum desses encontros posteriores, contudo, senti que consegui disfarçar o constrangimento por não ter conseguido evitar a destituição do poder familiar que the tirara seu filho.

O tempo havia sido um fator crucial para o desenrolar dos eventos que giraram em torno de meu encontro com Mercedes. A conversão jurídica da pena em medida de segurança não só instaurara a imprevisibilidade de sua custódia, como também fizera com que seu caso fugisse das prerrogativas do Marco Legal da Primeira Infância, o qual, através do programa Mães do Cárcere, poderia ter sido um fundamento legal para um habeas corpus que lhe permitisse cumprir prisão domiciliar. Seu caso era particularmente intrigante porque nunca cheguei efetivamente a localizar exatamente quando se deu o 
ponto de conversão entre pena e medida de segurança. De todo modo, a conversão inviabilizou a única maneira que conhecia na tentativa de manter Marcos sob sua guarda ou, pelo menos, sob os cuidados de alguém de sua família como ocorrera com a outra filha, porém dessa vez com sua anuência.

Diante desses eventos, então, os trâmites de documentos enleiam diferentes atores e entrecruzam diferentes tempos, entrecortados por imprevistos: o tempo da demanda anotada no caderninho já está atrasado em relação à sua devolutiva após o intervalo de quinze dias; o tempo pretérito do (não)dito ou do "fato" em que uma certa versão da "história” de Mercedes está escrita em autos jurídicos, e como ela é reiteradamente atualizada, é o que promove sua custódia temporalmente indefinida; o tempo de estudo de seu processo penal é demasiadamente retardatário ante o tempo determinante para a adoção de seu filho.

Chegado a este ponto, então, cabe recolocar os questionamentos que iniciaram este capítulo. Para onde as histórias de vazamento do texto do relatório, das minhas parcerias com Mercedes, bem como com demais instâncias estatais e de seu processo penal nos levam e qual a relação delas com o abolicionismo penal? Como tentativa de abarcá-los proponho uma última história antes de encerrar este capítulo.

Certa feita, conversava com o coordenador nacional sobre o desconforto de, ao ser parte da política de visitas às unidades prisionais, sentir ser "engrenagem da máquina que se tenta pifar”. Diante dessa inquietação tão recorrente no próprio GT, ele replicou, para minha surpresa, que era muito bom que tivesse essa percepção num tom quase que condescendente. $\mathrm{O}$ que eu tentava fazer e, devo admitir, com um certo receio, era também colocar minhas críticas sobre esse trabalho pastoral que, não raro, resulta em cumplicidades ou atitudes que pareciam em nada contribuir com mudanças substanciais. Muito ao contrário, era um trabalho que frequentemente redundava em circularidades aparentemente inócuas: o atendimento às demandas de pessoas privadas de liberdade dificilmente faziam muito além de duplicar ou suprir funções cotidianas do sistema do sistema carcerário, sem propriamente atacá-lo. Sob determinado ângulo, como procurei discutir tanto nesta dissertação quanto no momento dessa conversa, as visitas poderiam ser, potencialmente, uma prática infligidora de violência nessa duplicação ou suprimento de faltas. 
O que me intrigou foi seu tom de obviedade à minha colocação, ressaltando enfaticamente: "lógico que somos parte! Não tenha dúvida quanto a isso". Em seguida, continuou sua fala contando uma parábola cuja origem desconheço e tampouco me recordo que ele tenha esclarecido sua proveniência. De todo modo, era sobre "bebês na cachoeira" e assim versava: é importante retirar o corpo do bebê do rio e enterrá-lo, assim como o é salvá-lo do afogamento a tempo. E, igualmente importante, é descobrir por que bebês estão sendo jogados cachoeira abaixo.

Parecia que, novamente, eu era como "aquelas pessoas" com quem Jesus fala através de parábolas, que "escutam e não ouvem, nem entendem" (Mateus 13,10-17), porém dessa vez com o agravante de não entender nem as parábolas. Constrangido por não ter compreendido absolutamente nada e achando estranha a metáfora com bebês numa cachoeira, rapidamente voltei a falar e continuei repisando que, embora reconhecesse a importância de outras ações da $\mathrm{PCr}$ para além das visitas, não tinha tanta certeza quanto ao propósito das idas periódicas a unidades prisionais tomando o abolicionismo penal como diretriz política. Voltando ao seu tom complacente, retorquiu que achava uma opinião demasiadamente unilateral pois não levava em conta como o outro entendia minha presença no cárcere. Meu posicionamento, a seu ver, era ofuscado pela sensação de inutilidade e não abria margem para outros entendimentos do encontro com a pessoa senão aqueles que refletissem minhas próprias impressões, pautadas exclusivamente pela ineficácia.

Confesso que saí insatisfeito da conversa pois parecia não ter provocado nenhuma conclusão a respeito de minha colocação. Como não voltei a conversar sobre os bebês na cachoeira com o coordenador nacional, não tenho pretensão de fazer uma interpretação fiel a um suposto sentido único nem àquele que pretendeu me transmitir, se é que houve de fato essa pretensão. O ponto que acho relevante sublinhar é que, por alguma razão, essa parábola continuou "ressoando" nos meus pensamentos sobre abolicionismo penal, o que me motivou a tecer uma possível interpretação em interface com as histórias até aqui contadas.

Em primeiro lugar, a imagem do bebê sugere ideias de dependência e vulnerabilidade, que despertam o ímpeto do cuidado, de uma vida frágil que precisa ser protegida para sobreviver. Acredito que essa relação se aproxima da "economia moral" (Fassin, 2005) que procurei discutir nos capítulos 1 e 2, no que concerne a como a relação 
desigual instaurada pela "compaixão" (ibid) não deixa de ser repressiva, sendo, também, semelhante ao que Foucault (2008) nomeia de "poder pastoral", ou seja, o exercício do cuidado como uma prática de poder. Nesse sentido, a vulnerabilidade do bebê pode ser justaposta à do rebanho, que necessita de um pastor para protegê-lo e conduzi-lo.

Além disso, a parábola mobiliza um certo paradoxo entre "ver" a cachoeira e o modo de "agir" nela, recuperando as palavras caras à Teologia da Libertação e que sintetizam o imbricamento entre teoria e prática, como discutido no capítulo 1 . O centro desse paradoxo parece estar no modo de "julgar" essa "realidade", que opera em incompatibilidade temporal com a ideia suscitada pela cachoeira. Dito de outro modo, a cachoeira pressupõe um rio que corre, movido por uma correnteza, inferindo uma sequência linear de eventos embora eles tenham sido contados de trás para frente: seguindo o fluxo fluvial, e, portanto, contrário à sequência da narrativa, primeiramente temos o arremesso de bebês, seu afogamento e, por fim, sua morte no leito do rio. No entanto, a atitude para com os bebês, tal como me foi contada, não estabelece uma ordem de prioridades, embora pareça enfatizar, ao inverter a ordem do correnteza, o plano que, dentre os três, mais evoca a noção de proximidade - o recolhimento do corpo que jaz na margem a fim de realizar seu enterro. Os três momentos foram colocados como equivalentes em termos de importância, ainda que descobrir a causa do arremesso seja o ponto crítico que resolve todo o problema desse infanticídio. Talvez a ênfase no momento de enterro seja uma tentativa de contrabalançar a pressuposição que a grande chave do dilema é minar a causa dos arremessos.

Se levarmos a parábola como representativa do abolicionismo penal, uma vez que ela foi evocada quando disse que não visualizava o fim de prisões no trabalho de visitas cotidiano, é possível dizer que ela sugere um olhar menos de sucessão do que de concomitância. Isso é reforçado pelo fato de que, como consequência da equivalência de importância dos três momentos, a tarefa de se traçar linhas de início e término dessa história torna-se um complicado desafio. Não se deixa claro exatamente por onde começar nem terminar; esses momentos acontecessem ao mesmo tempo.

Fazendo, finalmente, o paralelo com o que contei neste capítulo, entendo que existe uma postura política imprescindível em confrontar temporalidades, tão política quanto o confronto a "espaços de aniquilação" (Relatório Hospitais-Prisão, 2018:61). O "tudo teve início" escrito no processo de Mercedes é o ponto que se desdobra para a 
captura de suas palavras "caluniosas", bem como seus "silêncios", como prova cabal de sua indiferença e de sua "fúria", explicação única do crime de palavras proferidas e escritas. O movimento de sua "história", o qual sugeri como espiralar uma vez que cada repetição das situações narradas é um passo em direção à sua sentença, na verdade já começa com seu fim previsto: o "destempero" não pode ter outro desfecho que não o manicômio judiciário. Questionar seu "tudo teve início" é, portanto, indissociável do questionamento de seu fim e era isso que, juntos, tentávamos fazer.

Embora ela já estivesse no HCTP, o fim de sua história permanecia em aberto porque a grande questão era a iminente adoção de seu filho; parecia factível evitá-lo ainda que fosse um desafio. Entretanto, como disse anteriormente, Mercedes não era reduzida somente a essa história em particular, o que não quero dizer que faça dela menos importante. Ao contrário, proponho que esteja, assim como os bebês, em igual importância com outras histórias que lhe enredam também. Reduzi-la a essa é, inevitavelmente, seguir a "história" espiralar de uma cadeia estanque de causas e efeitos, sempre previstos e naturalmente decorrentes. Entendo também que, por mais que o "fim" esperado não fosse a adoção, proponho questioná-lo quanto a esse estatuto, afinal, se é preciso confrontar a naturalidade do "tudo teve início", por que haveria um "tudo terminou"? Por que não poderia ser uma mudança brusca de rumo de uma de suas muitas histórias e não o fim da "história" compatível com moléstia mental?

Imprevistos também não faltaram na reta final de produção do Relatório Hospitais-Prisão, o que, ao fim das contas, não inviabilizou seu lançamento. Não quero com isso opor uma "história malsucedida" a uma "bem sucedida", num sentido quase heroico. Se o relatório não deixa de se enlear com as histórias que lhe dão embasamento, como discutimos no capítulo anterior, seria no mínimo contraditório fazer uma análise em termos de derrota e vitória. O ponto aqui é que por mais indesejáveis que sejam os imprevistos, eles têm a faceta de provar que a "história" no singular não é um "fato", como se querem fazer crer os papeis, mas sim uma construção silenciadora de seu plural.

Assim, vejo que o relatório não tem um "tudo teve início" e consequentemente "um tudo terminou" uma vez que não faria sentido, sob esse enfoque, tomar a sua redação como início e seu lançamento como fim. Como parte da "casa”, tal como propus no capítulo anterior, esse documento integrante das "tramas" dos "espaços de aniquilação" 
segue em concomitância com as histórias que o motivaram, mesmo após a conclusão de sua escrita; ele não é, de modo algum, um após.

Como bem aponta João Biehl, recuperando Derrida, “a escrita é inseparável do devir e este processo envolve a invenção de uma outra pessoa: o leitor” (Biehl, 2008:444). As relações entre escrita e finais abertos é tema de sua etnografia, em que traz a história de Catarina, uma mulher abandonada numa instituição de saúde por sua família e alvo de intensos processos de "farmaceuticalização". Como um processo alinhado com as imbricações entre capitalismo e políticas de saúde mental, o autor ajusta o foco para como essas novas tecnologias farmacológicas incidem sobre Catarina, empurrando-a para uma dimensão de não "reconhecimento" enquanto vida (ibid:416). No entanto, a escrita em seu caderno nesse cotidiano de abandono, o qual Catarina chama de dicionário, é o próprio ato de reelaboração de si mesma, denotado, inclusive, pela fusão de seu nome com um dos medicamentos de que fazia uso. Como afirma Biehl citando as palavras de Catarina, as diferentes combinações resultantes, tais como anagramas, eram redefinições de sua subjetividade pulsante em desejo e em contínua formação: "Porque Catarina não é nome de uma pessoa... verdadeiramente não. É o nome de uma ferramenta, de um objeto. A pessoa é um Outro. Katkine, Catieki são nomes de pessoas.” (:444).

A história de Catarina é também um exemplo de recusa de pontos finais, de uma subjetividade que sempre escapa, imprevisivelmente, às tecnologias que procuram reduzi-la à morbidez. A escrita, portanto, mais do que mera "extensão da comunicação oral", traz uma "força de ruptura inerente ao ato próprio de escrever" (Das, 2007:163, tradução minha).

Essa "força de ruptura", tanto quanto a ideia de escrita como "devir", demarcam o escape à intencionalidade desse ato, que exige um compartilhamento com um "leitor". Acredito que no meu caso com Mercedes, as escritas e leituras tinham como baliza a incompatibilidade com expectativas prévias, porquanto fomos obrigados a lidar com o contingencial e imprevisto das relações que acionávamos por meio dos papeis. Assim, as escritas dependiam das leituras e leituras dependiam de escritas, obrigando-nos a reconhecer que significados unilaterais não nos levariam a lugar nenhum. As parcerias forjadas, fosse com ela ou com funcionários(as) implicavam que, para as histórias ganharem movimento, era preciso tecer tramas com o Estado, ao mesmo tempo que se empreendia uma estratégia contra um ato de Estado, a saber, a destituição do poder 
familiar. Talvez fosse algo próximo disso que o coordenador advertiu, naquela nossa conversa, sobre o perigo de significados prontos, de ofuscamentos unilateriais que nos levem a posturas que mais entravem histórias do que as movimentem.

Um último ponto que gostaria de abarcar fazendo relação com a parábola do bebê na cachoeira diz respeito a um impasse provocado pela sugestão de concomitância que lhe parece subjacente. Se os três momentos são igualmente importantes, como estar em três espaços ao mesmo tempo, isto é, no arremesso, afogamento e enterro? A fim de responder essa pergunta, começo com a indagação provocada pela geógrafa feminista Doreen Massey (2008): “O que poderia significar (...) questionar esse hábito de pensar o espaço como uma superfície? Se, em vez disso, concebêssemos como um encontro de histórias, o que aconteceria às nossas imaginações implícitas de tempo e espaço?” (Massey, 2008:23).

Assim como Biehl (2008) e Das (2007), Massey (2008) também se aporta em Derrida com o objetivo de questionar criticamente uma concepção de espaço meramente territorial e operante por separações e isolamentos, que ignora a "topografia do poder"55 por ser estritamente "tabular" (Massey, 2008:106). Derrida seria certeiro em afirmar, então, que "o efeito da espacialização já implica uma textualização" (Derrida, 1994:15 apud Massey, 2008:88). Em oposição a tal conceituação moderna de espaço, a autora procura politizar a espacialização no sentido de defini-la como "uma multiplicidade de histórias-até-agora", ou “como devires coetâneos" (:267).

Seu ponto de que o espaço é uma eventualidade, construído pela conjunção de múltiplas trajetórias, é o que lhe permite fazer o desdobramento para nossa implicação com o aparentemente longínquo no tempo ou distante no espaço, entendendo essa sensação de apartamento como fruto de um certo modo de entendimento espaço-temporal e não como decorrência de um fato objetivo. Para clarear seu raciocínio, a autora nos oferece um exemplo que julgo elucidativo para a compreensão de suas ideias principais. Trata-se de uma viagem de trem partindo de Londres para a cidade de Milton Keynes. Em lugar de entender como uma viagem que percorre uma superfície espacial, Massey entende que se trata de uma viagem "através de trajetórias", que encapsulam e mesclam espaços e tempos. Assim, a árvore vista da janela do trem é produto do que um dia foi

55 Sobre esse ponto, a autora também recupera o conceito de "espaço anacrônico" de Anne McClintock (2010), que, basicamente, exprime a ideia imperialista de um tempo permanentemente anterior do território conquistado frente ao "civilizado" como parte do processo de dominação (ibid:174). 
uma semente e imagem fugaz do que um dia estará extinto, assim como a Londres que você, enquanto passageiro, deixou já não é mais a mesma. Tanto a árvore quanto a capital britânica são trajetórias. Do mesmo modo, o destino final não está a sua espera, ele está em constante modificação e seu momento de chegada é tão somente o ponto em que você ligar-se-á “à coleção de histórias entrelaçadas das quais aquele lugar é feito" (:176).

Creio que o espaço como "esfera de relações", como "multiplicidade contemporânea" faz com que uma "topografia dos fluxos" ganhe relevo (:274) e lance luz sobre como o "espaço de aniquilação" dos HCTPs não se faz por seu isolamento no meio da reserva ambiental do Juquery. Ao contrário, as trajetórias que o constituem como espaço são aquelas que o perfuram dos mais distintos modos e que, ao fazê-lo, denunciam a falácia das distâncias territoriais como justificativa de não implicação com trajetórias que nos constituem. A história aberta da adoção de Marcos, portanto, deve ser contada não por compadecimento, mas pelo que nos diz em termos de implicação. Desconhecê-la não nos permite inferir que não seja nossa história também.

Gostaria de concluir, então, que não só é possível estar em três ou muito mais lugares ao mesmo tempo como é preciso que estejamos, porque, na verdade, já estamos. $\mathrm{O}$ reconhecimento dessa coetaneidade e o enfrentamento à linearidade temporal e espacialidade territorial é o mesmo que permite que pontos finais sejam sempre adiados e as maiúsculas iniciais perpetuamente retrocedidas. Longe de ser uma angústia ao sugerir que o "mundo sem prisões" está encarcerado no horizonte inalcançável, podemos deslocar nosso ângulo de visão de histórias supostamente acabadas ou ainda a serem concretizadas em direção à coletividade de "histórias-até-agora", com seus respectivos finais abertos, que, em alguma medida, são também as nossas próprias. 


\section{A Antropologia e o Abolicionismo penal como "histórias-até-agora" que contam histórias: para onde nos levam as etnografias?}

No ensaio "O medo não consegue dormir: sobre os poemas de Theodor Kramer", a renomada escritora romena Herta Müller expõe uma breve biografa do poeta austríaco perseguido pelo nazismo alemão, refletindo sobre como os tempos sombrios se fazem presentes em sua obra. Em certo momento, Müller chega à conclusão de que a violência contra a população judaica "não começa pelo extermínio dos judeus nos campos de concentração, mas anos antes, com o roubo da naturalidade nas casas, cafés, lojas, bondes ou parques pela maioria dos correligionários" (Müller, 2013:222). Em seus poemas, o atroz, segundo ela, aparece trivialmente como quase sem intenção, o que lhe confere um ar ainda mais aterrorizante do que se escrito de forma explícita. Banal e extraordinário não só aparecem assustadoramente próximos, mas beiram o imperceptível e o inominável. É justamente essa invisibilidade anônima da naturalidade, no entanto, a condição base do próprio estatuto de natural, ordinário. A naturalidade "está no momento e não tem um nome, para existir ela precisa se manter despercebida, porque nós também podemos nos deixar despercebidos nela" (ibid, p.219).

Sua reflexão é instigante por uma dupla provocação. Em primeiro lugar, propõe uma antecedência para o que seria o início da violência do holocausto, antes mesmo dos campos de concentração receberem levas e levas de pessoas para a morte. O segundo ponto é a desmitificação de que essa demarcação de começo exija a brutalidade ou o inominável como parâmetro de referência. Ao contrário, a violência se entranha sorrateiramente no cotidiano. Assim dito, pergunto: se fizermos o mesmo exercício de retroação para o fenômeno de encarceramento, onde pararíamos?

O capítulo anterior procurou defender que, menos importante do que traçar limites de início e término de histórias, seria perceber o quão enleados estamos nessas "históriasaté-agora”, mesmo àquelas que aparentemente não nos dizem respeito. Diante disso, proponho uma reformulação da pergunta anterior no seguinte sentido: quais seriam, então nossos enleamentos com o cárcere sendo ele também uma "história-até-agora"? Em lugar de retroceder, então, tal interrogação permite deslocar o foco daquilo que supostamente seja um legado anterior que se perpetua no presente como resquício em direção a um processo dinâmico, em constante transformação, no qual o que se nos apresenta na atualidade não se deve à resistência de algo que é mero resto. Isso seria pressupor que o 
arrefecimento seria norteador desse processo, permitindo inferir sua inevitável extinção. Antes, o que pretendo provocar é como ele pode ser reatualizado em igual ou maior potência sob novas formas e roupagens.

Além disso, penso que a proposição do cárcere como "história-até-agora" não pode vir descolada de outras "histórias-até-agora" que lhe cruzam e se lhe justapõem, sendo, uma delas, a "trajetória" da Antropologia Social enquanto ciência. Nesta última seção da dissertação, portanto, meu intento é discutir, tomando emprestado a analogia de Massey (2008), quais os compromissos, limites e responsabilidades que assumimos quando embarcamos num trem em movimento ainda que sejamos apenas um de tantos passageiros. Nesse sentido, minha dissertação de Antropologia Social, ao mesmo tempo que tenta contar algumas histórias, é, ela mesma, uma dobra entre histórias-até-agora do sistema carcerário, do qual os manicômios judiciários são parte, e da Antropologia Social, enquanto ciência.

Como forma de começar esse debate, transcrevo dois parágrafos da apresentação "Desencarceramento ou Barbárie" da Agenda Nacional pelo Desencarceramento (edição 2016-2017), assinada, como dito na introdução desta dissertação, pela PCr juntamente com mais de quarenta outras organizações:

Ao caráter massivo do encarceramento no Brasil soma-se o caráter seletivo do sistema penal, expresso na discriminação de bens protegidos e de pessoas alvejadas: de um lado, apesar das centenas de tipos penais (crimes definidos em lei) constantes da legislação, cerca de $80 \%$ da população prisional está presa por crimes contra o patrimônio (e congêneres) ou pequeno tráfico de drogas (que somam, ao todo, não mais do que 5 tipos penais); de outro, apesar da multiplicidade étnica e social da população brasileira, as pessoas submetidas ao sistema prisional têm quase sempre a mesma cor e provêm da mesma classe social e territórios daquelas submetidas, historicamente, às margens do processo civilizatório brasileiro: são pessoas jovens, pobres, periféricas e pretas.

Tal seletividade marcada pelo racismo é característica da formação social e econômica brasileira desde a colonização portuguesa. Do navio negreiro às senzalas, do pelourinho e do capitão do mato às violentas abordagens policiais, passando pela lei de vadiagem, criminalização de condutas e das culturas originárias ameríndias, o sistema penal desvelase não como remédio à "criminalidade", como oficialmente se declara, mas sim como perseguidor de corpos negros de mulheres e homens, revelando o racismo estrutural que o perpassa e o determina. Inserese, nesta mesma lógica racista, o genocídio da juventude preta e pobre, que é historicamente marginalizada, estigmatizada e indesejada (Agenda Nacional pelo Desencarceramento, 2016-2017:6, grifos originais). 
Os dois parágrafos acima colocam em perspectiva histórica a seletividade do sistema carcerário, fazendo não pares de oposição, mas de continuidade entre eventos que marcaram a história do país: navio negreiro e senzalas; pelourinho e abordagens policiais. Uma perspectiva não muito distante é a da filósofa estadunidense Angela Davis, também contumaz defensora do abolicionismo penal. Em seu livro Estarão as Prisões Obsoletas? (2018), a autora insere a instituição da prisão no contexto sócio-histórico dos Estados Unidos, país marcado pelo regime escravocrata e pela seletividade racial, de classe e gênero através da qual o sistema penitenciário opera. Não há, na opinião de Davis, como entender o racismo estrutural imperante na atualidade sem levar em conta os atravessamentos temporais da escravidão, a qual esteve no seio, durante séculos, do sistema social e econômico do país. Há, portanto, uma relação inexorável entre escravidão e encarceramento como violências flagrantemente perpetuadoras de desigualdades em termos desses marcadores sociais. E, segundo Davis, não muito diferente dos que achavam que era possível buscar formas de humanizar o regime escravocrata, existem os atuais defensores do reformismo do sistema carcerário.

O que significa, então, ser antropólogo(a) nesse contexto? Como estamos política e historicamente implicados? Em uma de suas visitas à Penitenciária Feminina de Santana, na capital paulista, Natália Padovani (2015) teve sua posição enquanto antropóloga acionada por uma de suas interlocutoras, de nome Patrícia, em situação de privação de liberdade. Frente a um ato delituoso que cometera no seu passado e do qual manifestava profundo arrependimento, Patrícia demandou a Padovani que ela, na sua posição de antropóloga, concomitante à sua função de agente pastoral, atestasse-a enquanto louca para seu marido. Essa situação particular serve-lhe de mote para refletir sobre a assimetria de relação que é parte do fato de ser antropóloga, mas cuja dinâmica não é apenas de inflição de poder unilateral, senão também do agenciamento desse poder por outros(as), como forma de obter resultados desejados.

Nesse sentido, importava menos a Patrícia saber o que é a antropologia como área do saber do que subverter a seu favor os saberes e técnicas que supunha Padovani deter para que lhe ratificasse seu diagnóstico como louca e provasse a seu marido que seu ato delituoso era fruto de um delírio. O ponto, no entanto, é que a relação ali tecida não pode ser compreendida como uma assimetria de apenas dois indivíduos, uma vez que isso seria obliterar a história à qual as duas mulheres estão enredadas. Como bem esclarece 
Padovani, utilizando a comparação com o personagem Indiana Jones que uma de suas interlocutoras fez na tentativa de entender o que seria "ser antropóloga":

\begin{abstract}
meu corpo é produzido pela justaposição das figuras dos juristas brancos, missionários cristãos, cientistas "donos das verdades" sobre, se não os povos colonizados dos séculos passados, os bárbaros encarcerados da atualidade que povoam os noticiários televisivos: "bandidos sem escrúpulos". Ser "tipo Indiana Jones" é, nesse registro, ser situada frente a uma carga histórica de posicionamentos assimétricos de podersaber que configuraram a prisão. É, portanto, ser tramada frente à figura do "bandido" produzida pelos discursos das "classes perigosas". Figuras que são, aqui, agenciadas (Padovani, 2015:131).
\end{abstract}

Como bem lembra Padovani (2015), mobilizando Mariza Correa (2001), existe uma intrincada conexão histórica entre a antropologia e os discursos pseudocientíficos produtores de "classes perigosas". Em solo brasileiro, a Escola Nina Rodrigues frutificou nas searas da antropologia e medicina legal, bebendo principalmente da teoria da degeneração de Agassiz e Morel (ibid:129). Essa perniciosa relação interdisciplinar é também abordada na obra Tributo a Vênus: a Luta da Sífilis no Brasil, da Passagem do século aos anos 40 (1996) de Sérgio Carrara, a qual traz um rico panorama de como essas teorias eugenistas em voga nesse período histórico ganharam matizes próprias em solo brasileiro. A emergência da epidemia venérea mobilizou áreas como psiquiatria, antropologia criminal e criminologia, todas fortemente impactadas pela noção de “degeneração". A conjunção de saberes conformou também a emergência de uma nova especialidade, os sifilógrafos, para os quais o entendimento da doença era indissociável de categorias como raça, nação, família, entre outras. Desse modo, a sífilis e outros "flagelos sociais", como eram chamados, eram tanto um problema da ordem da saúde pública quanto de ordem moral, porquanto não era simplesmente uma ameaça à sociedade, mas "suas origens estavam enraizadas na própria organização social e em certos valores socialmente estabelecidos" (Carrara, 1996:15).

Relembrar, então, o apelo à transformação de pedras de tropeço em degraus de escada, o qual vi fixado em uma das instalações do HCTP de Taubaté, parece apenas um momento efêmero de uma trajetória muito mais longa que a minha ou da própria instituição: entre as várias histórias grafadas naquela frase , a da antropologia é também uma delas, assim como dos meus entrecruzamentos com essa "história-até-agora". As trajetórias seguem seus rumos nesses enunciados, bem como nas expressões que ouvíamos designando "pacientes" como "rebaixados" ou "cronificados". O outro "ritmo" 
a que lhes era atribuído não apenas os classificava em termos de patologia, mas os alocava em outro tempo. Afinal, a escada ainda não foi ascendida e, embora contem com o cuidado e benevolência dos que já estão no topo, a eles não deixa de recair a responsabilidade por sua própria ascensão.

Essas são também "histórias-até-agora" que ressoam nos caderninhos e corpos. Assim como o caderninho da "antropóloga" era também acionado como instrumento de poder (Padovani, 2015), o meu tampouco passou despercebido. Algumas pessoas que o viram, agenciaram-no para que demandas fossem encaminhadas, fossem pontuais ou densas; algumas tão densas a ponto de exigir que "tudo" deveria ser anotado, como foi com Daiana. Em outros momentos, contudo, dispensar o caderninho dava lugar aos corpos, através dos quais as trajetórias igualmente falam.

O conceito de "história incorporada" (embodied history) elaborado por Didier Fassin (2007) parece traduzir com precisão essa interface que faz do corpo uma forma de linguagem. Em When Bodies Remember: Experiences and and Politics of AIDS in South Africa, Fassin empreende uma densa análise sobre a epidemia de AIDS no contexto sul africano do pós-apartheid. Com o ocaso do regime segregacionista, a instauração da Comissão de Verdade e Reconciliação na África do Sul buscou a construção de uma nova nação não-racializada a partir da coletivização do sofrimento de décadas de violência estatal. A noção de "ubuntu" seria central como operacionalização de intersubjetividade no que se intentava construir como memória coletiva, traduzindo a ideia de que "uma pessoa é alguém através de outras pessoas", o que implica que "o que te desumaniza também me desumaniza inexoravelmente" (Tutu, 1999:29 apud Moutinho, 2012:6).

Não obstante essa tentativa, a pesquisa etnográfica de Fassin aponta para o quanto a "história da epidemia é parte integral da história de segregação racial na África do Sul" (Fassin, 2007:132, tradução minha). Isso porque a desigualdade com que corpos brancos e negros foram afetados pela epidemia nos anos 90 do século XX denuncia o quanto a ruptura com o passado deixou a desejar. Os corpos, nesse sentido, não são expressões de narrativas ou de memórias, eles são em si a história que insiste em se repetir, onerando seletivamente corpos negros uma vez que a manifestação da AIDS não se faz apartada de fatores relacionados à "desigualdade, violência e deslocamentos humanos", flagrantemente distintos entre os grupos raciais, sendo esses elementos integrantes de "estruturas historicamente constituídas" contra as quais nenhuma política de 
esquecimento era párea (ibid:180, tradução minha). Em suma, compreender corpo como "história incorporada" é o mesmo que dizer que, no caso estudado por Fassin, "a história inscreve o corpo com AIDS” (:192, tradução minha).

Conhecer Daiana naquela visita, à luz dessas considerações, não significou conhecer quem era ela e quais as causas de suas cicatrizes. Penso que nosso encontro passou pelas possibilidades e limitações do reconhecimento do Outro, expressos pela palavra, mas sobretudo pelo corpo. Assim, suas cicatrizes de queimaduras e cortes são certamente parte de sua história de vida, mas não era essa história que se fazia presente naquele momento. Como bem assevera Das (2007), a diferença entre falar e mostrar não é a simples distinção entre palavra e gesto, mas a demarcação de uma ruptura na qual "o gesto pode nos dizer que formas de vida, que formas de morrer, vêm a ser o solo no qual palavras podem ou não crescer" (Das, 2007:94, tradução minha). O corpo, portanto, a um só tempo linguagem e história, clama reconhecimento não pela transmissão da dor tal como ela é sentida, mas interpela os modos pelos quais estamos implicados naquilo que nos é demandado a reconhecer e, ao fazê-lo, permite seu compartilhamento.

Cabe, então, a seguinte pergunta: quais as possibilidades e limitações da Antropologia para o reconhecimento do Outro e qual sua relação com o abolicionismo penal? Essa preocupação ecoa, em certa medida, nas reflexões de Johannes Fabian (2013) a respeito da etnografia e seu caráter autobiográfico, uma vez que a escrita sobre o Outro depende irrevogavelmente da própria experiência do autor. Cito:

\footnotetext{
a disciplina [antropologia] 'lembra' que adquiriu seu status científico e acadêmico ao se apoiar em aventureiros e uso de suas narrativas de viagem, que durante séculos tinham sido o gênero literário apropriado para transmitir o conhecimento sobre o Outro. Em muitos aspectos esta memória coletiva de um passado cientificamente duvidoso atua como um trauma, bloqueando uma séria reflexão sobre o significado epistemológico da experiência de vida e suas expressões autobiográficas (Fabian, 2013:114).
}

Uma das ideias centrais de Fabian é que o empreendimento colonial do qual a Antropologia é fruto não envolveu apenas uma dominação espacial, mas uma negação da coetaneidade, isto é, o Outro como objeto de estudo da disciplina está sempre alocado num tempo anterior ao do etnógrafo, o que faz disso uma questão epistemológica fundante dessa ciência. Para o autor, o próprio trabalho de escrita reatualiza essa distinção na medida em que ele se dá posteriormente ao trabalho de campo, o que implica, necessariamente, que o referente do discurso antropológico esteja no pretérito de quem 
escreve a seu respeito. Com efeito, a prática da etnografia não raro resultou em produções, inclusive recentes historicamente e oriunda de países não-centrais, insistentes em reiterar visões etnocêntricas e pautadas pela ideia de "atraso" de determinados grupos sociais. É o que mostra, por exemplo, a revisão bibliográfica empreendida por Sérgio Carrara e Júlio Simões a respeito de como vem sendo tematizada a homossexualidade masculina pela Antropologia desde fins da década de 70. Observam os autores que o estudo desse grupo social esteve fortemente marcado pelo "exotismo", a serviço de uma certa construção da identidade nacional brasileira (Carrara e Simões, 2007).

Diante de um legado histórico nefasto, então, de que forma ser parte, enquanto pesquisador, dessa seara científica? Se o "estar fora" não existe, como bem pontuou o coordenador nacional na nossa conversa permeada pelos bebês na cachoeira, pois inevitavelmente somos parte e não há dúvida quanto a isso, o que parece resultar inferido é o desafio de fazer um enfrentamento "por dentro". Contar histórias talvez seja um primeiro e importante passo, ou, melhor dizendo, recontar histórias hegemônicas em voga há muito tempo a partir de outras histórias. Nas palavras de Donna Haraway (1995):

\footnotetext{
A História é uma estória que os entusiastas da cultura ocidental contam uns aos outros; a ciência é um texto contestável e um campo de poder; o conteúdo é a forma. Ponto. A forma na ciência é retórica artefactual-social de fabricar o mundo através de objetos efetivos. Esta é uma prática de convicções que mudam o mundo e que tomam a forma de incríveis objetos novos - como os micróbios, os quarks e os genes (Haraway, 1995:10).
}

Para Haraway, contar histórias é, antes de mais nada, um projeto político. Os entusiastas da cultura ocidental de que nos fala Haraway são justamente os apologistas de uma história univocal, pretensiosamente capaz de delimitar o "tudo teve início". Embora a autora não se defina como antropóloga, suas preocupações em prol de um projeto científico feminista reverberaram interdisciplinarmente, tecendo frutíferos diálogos com outros(as) autores(as), dentre as quais a antropóloga Anna Tsing.

O convite de Anna Tsing a "recusarmos" o estabelecimento de fronteiras entre "natureza" e "cultura", cujas tentativas de delimitação teórica são tão caras à antropologia, é consonante com algumas das proposições de Haraway, uma vez que não propõe meramente um novo modelo ou teoria ao que está presumivelmente estabilizado sob a égide de ciência, mas um olhar para a própria fonte de produção epistemológica, 
isto é, para as relações hierárquicas de saberes que se constroem na alteridade (Tsing, 2015:180).

Seguir o "argumento fúngico" de Anna Tsing (2015), por exemplo, à luz da recusa entre as fronteiras entre natureza e cultura, é enfrentar a narrativa da "domesticação", tão arraigada na história da "Conquista Europeia" do capitalismo colonial e, com isso, escapar às narrativas univocais, afeitas unicamente ao "controle" e "impacto" humanos na natureza. Em seu artigo Margens Indomáveis: cogumelos como espécies companheiras, atentar para os fungos é um exercício tanto epistemológico quanto político na medida em que a interdependência biológica com que constroem suas relações com outras espécies de um ecossistema é, ademais de uma forma de existência, um desafio aos pressupostos científicos da superioridade humana. Para ela, o estabelecimento de um conceito de "natureza humana" atemporal não veio dissociado do endosso a ideologias autocráticas e militaristas várias, o que coloca em evidência como tal conceito foi apropriado e reatualizado para legitimar, histórica e culturalmente, práticas de predação intra e interespécies.

Tsing, portanto, propõe uma releitura do capitalismo moderno, isto é, uma outra forma de contar sua história, na qual os enredamentos entre fungos e humanos ganham protagonismo sob um outro prisma de "natureza humana", mutável e contigencial, situado como "uma relação entre espécies" (2015:184). Essa etnografia multiespécies ou, dito de outro modo, sensível ao olhar para as "espécies companheiras" - ideia que, como ressalta a autora, procura dialogar com os aportes epistemológicos de Haraway - é subversiva à retórica masculinista da domesticação do meio ambiente tal como se fosse uma via de mão única, isto é, como se o controle humano sobre outros viventes se fizesse sem qualquer impacto ou influência desses sobre nós. Em suas palavras, "Onde uma orientação agrícola nos encoraja a imaginar uma relação unilateral entre humanos e nossos legumes comestíveis, cogumelos silvestres insistem em ecologias complexas, onde o controle é impossível" (Tsing, 2018:369). Portanto, deslocar o foco de grandes narrativas monolíticas de supremacia humana para as tramas em suas complexidades e finais sempre abertos é um imperativo que, segundo a autora, deve ser objeto de preocupação epistemológica de cientistas sociais e naturais para uma "pesquisa profundamente histórica e precisamente situada" (ibid:370). 
Etnografar como uma prática de contar e rememorar histórias pode ser um entre tantos modos de buscar tais "ecologias complexas", que talvez tenham o potencial de desestabilizar a "história” do "tudo teve início". E, assim, como o narrador de Benjamin, o etnógrafo sucateiro "abre-se aos brancos e buracos" (Gagnebin, 2006:55), porque tem como premissa justamente a desconstrução de narrativas totalizantes e opacas, afinal de contas, “’Nós’ somos unidos por lacunas” (Cho, 2008:194, tradução minha).

As lacunas também denunciam os rumos sempre imprevistos das histórias, as quais não dispõem de enredos predeterminados. Arlene, por exemplo, foi alguém que me mostrou isso de maneira marcante. Ela também foi uma das pessoas com quem pude estabelecer uma relação mais próxima na ala feminina de um dos HCTPs e alguém que fez meu caderninho dispensável inúmeras vezes, dando lugar a conversas e, às vezes, desenhos no papel feitos em conjunto. Foi ela também a única a escrever no meu caderninho em certa visita; queria deixar-me uma mensagem.

Quando soube que tinha sido finalmente desinternada, meu primeiro sentimento foi de felicidade. Ela havia sido encaminhada para um CAPS em São Paulo onde residiria provisoriamente até ser transferida para uma residência terapêutica. Pouco tempo depois, no entanto, veio a meu conhecimento através de uma psicóloga do Centro de Atendimento Multidisciplinar da Regional Criminal da Defensoria Pública de São Paulo (CAMCrim), a qual estava trabalhando em seu caso, que Arlene não estava se adaptando muito bem à nova instituição e, por ter conhecimento de que éramos próximos, convidou-me para acompanhá-la em visita que faria à Arlene, no CAPS.

Enquanto ela e outra psicóloga do CAMCRim conversavam com a diretora da instituição, dirigi-me ao pátio onde uma funcionária me dissera que Arlene estava tomando sol. Assim que me avistou enquanto fumava um cigarro, ela esboçou um grande sorriso, dizendo, em seguida, meu nome em tom de surpresa.

Ficamos contentes de revermo-nos e passamos alguns minutos sentados no banco conversando, tentando recuperar com palavras o tempo que ficamos sem nos ver. Em determinado momento, interroguei-lhe sobre o que estava achando do novo lugar, ao que respondeu que estava detestando e queria voltar para o manicômio judiciário, perguntando, ainda, se eu tinha notícias de funcionários(as) e pacientes-detentas de quem era amiga. Sua resposta causou-me grande surpresa pois seu caso era justamente um dentre poucos no período em que atuei como agente pastoral que logravam a 
desinternação. Sua situação era ainda mais delicada uma vez que não dispunha de respaldo familiar e, não raro, esse fato contribuía para a manutenção da custódia ainda que a periculosidade fosse julgada cessada pelo perito e avalizada pelo juiz. Em outras palavras, muito(as) eram retidos em custódia não por uma suposta patologia, mas por não terem o que se espera pelo entendimento de "família".

Ainda assim, seu desejo era de retorno. Acredito, no entanto, que menos importante do que querer entender o porquê de sua vontade seja compreender o que isso diz sobre o abolicionismo penal quando este é entendido pura e simplesmente como fechamento de prisões e manicômios. Sob essa perspectiva, talvez "um mundo sem cárcere" esteja perigosamente próximo à história domesticadora e totalizante, que passa ao largo e na contramão de outras histórias, como as de Arlene, imune a possibilidades de compartilhamento, de visão e de escuta, habilidades essas que são tão caras ao trabalho pastoral. Desafiar-se ao compartilhamento é permitir-se a "soltar" a história, ainda que isso implique em lidar com o que possa se apresentar como o mais notório contrassenso, denunciando não a loucura do Outro, mas a arrogância de nossas próprias convicções.

Creio, portanto, ser importante relutar no preenchimento de todas as lacunas uma vez que é só a partir delas que uma "ética do emaranhamento" (ethics of entanglement) pode ser tecida através do reconhecimento de histórias outras (Cho, 2008:196). Enxergálas permite que visibilizemos não somente nossas implicações no que nos é demandado reconhecimento, mas os fios que desafiam temporalidades lineares, conectando várias histórias aparentemente desconexas.

Tal ação abre margem para refletirmos sobre algumas questões, dentre as quais: em que medida, então, massacres de presídios em pleno 2019 ecoam o massacre do Carandiru de 1992? Em que medida ecoam massacres estruturantes da História-até-agora do país? Percorrendo o mesmo emaranhamento talvez possamos também entender o que a invisibilização de massacres, a um só tempo históricos e cotidianos, nos dizem sobre velhas histórias, não somente sobre sistema carcerário, que insistem em se reatualizar. Atualmente, temos um cenário em que nossa "ordem e progresso" continua a todo vapor, afunilando-nos a visão de modo que não percebamos os rastros deixados no seu percurso. "Future-se" é a nova ordem de uma muito antiga História-até-agora ante a qual educação e saúde públicas não compartilham espaço a não ser como cacos de algo demasiado retardatário ao que se vem prometendo, desde há muito, como "progresso". 
Ouvir e escrever histórias penais abolicionistas, então, talvez seja um importante recurso do qual podemos nos municiar, sobretudo daquelas que, embora não as acessemos por completo, sejam suficientemente transmissíveis pelo que demandam em termos de implicação e coletividade. Nas palavras de Tsing:

(...) essas histórias são boas para serem contadas: boas não apenas para nos levar para as, frequentemente, angustiantes condições de vida na Terra, mas também para oferecer dicas sobre como acomodações multiespecíficas podem ser arranjadas apesar dessas condições (Tsing, 2018:380).

Por mais que o "presente etnográfico" tente nos iludir, essas outras histórias contra-hegemônicas não começam quando chegamos e nem terminam quando vamos embora, elas estão lá e aqui em seus respectivos cursos todo o tempo. Histórias sempre incompletas de abolicionismo penal podem ser mais atraentes do que a história de fim previsto do fechamento de prisões e manicômios. Não que ele não seja um fim importante, mas a ansiedade de obtê-lo pode ser demasiado ofuscante à percepção de muitos outros percursos que precisamos urgentemente nos implicar e percorrer em coetaneidade - não nos esqueçamos dos bebês na cachoeira.

Mas se não dispomos de um início nessas muitas histórias para começarmos há, pelo menos, vários convites ao nosso olhar e à nossa escuta mostrando-nos a possibilidade de "ver através da voz do Outro" (Cho, 2008:196, tradução minha). É preciso que estejamos atentos, pois, a tais convites, mesmo que, à primeira vista, possam parecer tão desimportantes quanto um bilhetinho que nos é entregue por uma apertada abertura ou tão inocentes quanto um inesperado pedido:

"Caio, vem cá que quero conversar com você. Anota tudo no caderninho"

Arlene escreveu sua mensagem em meu caderninho em suas últimas páginas. Restaram, após ela, oito páginas em branco. Prefiro lê-las não em termos do que não foi possível anotar nesses dois anos de registro de demandas, mas como uma expressão daquilo que prescindiu da escrita para continuar porque simplesmente não tinha como ter um ponto final; nunca precisou de um. Seus finais estão e continuam sempre abertos. Assim, faço a escolha de terminar (?) esta dissertação com oito páginas em branco. As histórias-até-agora que tentei aqui contar de Daiana, Lúcia, Nathan, Claudio, Mercedes e 
Arlene, bem como aquelas muitas que jamais cheguei a tomar contato, seguem, felizmente e a despeito de meu desconhecimento, seus muitos e imprevisíveis rumos.

"Querido Caio que você seja iluminado pelo por Deus que tudo que você realize todos teus sonhos sabe que você amigo muito legal. Quero que Deus ti der muita saúde paz e sonhos verdade.

Tchau que Deus te guarde

Si cuida tá amigo

Arlene" 


\section{Referências}

AMARANTE, Paulo. Novos sujeitos, novos direitos: o debate em torno da reforma psiquiátrica. Cadernos de Saúde Pública, v. 11, p. 491-494, 1995.

ANTUNES, Sara Vieira. Habitar entre grades: táticas de vida no cotidiano de uma penitenciária feminina. 2017. 1 recurso online (142 p.). Dissertação (mestrado) Universidade Estadual de Campinas, Instituto de Filosofia e Ciências Humanas, Campinas, SP.

BARROS, Andrea Saraiva de. Trajetória de criação da ala especial de medidas de segurança na Penitenciária III de Franco da Rocha: o circuito da periculosidade. 2018. 235 f. Dissertação (Mestrado em Psicologia: Psicologia Social) - Programa de Estudos Pós-Graduados em Psicologia: Psicologia Social, Pontifícia Universidade Católica de São Paulo, São Paulo, 2018.

BENJAMIN, Walter. Teses sobre o conceito da história, 1940. Obras escolhidas, 1987.

BIEHL, João. Antropologia do devir: psicofármacos—abandono social—desejo. Revista de Antropologia, p. 413-449, 2008.

BIONDI, Karina. Junto e misturado: Uma etnografia do PPC. São Paulo, Terceiro Nome, 2010.

Proibido roubar na quebrada: território, hierarquia e lei no PCC. Editora Terceiro Nome, 2018.

BRASIL. Lei no 7210, de 11 de julho de 1984. Institui a Lei de Execução Penal. Brasília, DF, 1984.

Lei $\mathrm{n}^{\mathrm{o}} 8.069$ de 13 de julho de 1990. Dispõe sobre o Estatuto da Criança e do Adolescente e dá outras providências. Brasília, DF, 1990.

Lei $\mathrm{n}^{\circ}$ 10.216, de 06 de abril de 2001. Dispõe sobre a proteção das pessoas portadoras de transtornos mentais e redireciona o modelo assistencial em saúde mental. Brasília, DF, 2001.

BUMACHAR, Bruna. 2016. Nem dentro, nem fora: a experiência prisional de estrangeiras em São Paulo. Tese de doutorado, Universidade de Campinas.

CARRARA, Sérgio. Tributo a Vênus: a luta contra a sífilis no Brasil, da passagem do século aos anos 40. SciELO-Editora FIOCRUZ, 1996.

Crime e loucura:o aparecimento do manicômio judiciário na passagem do século. Rio de Janeiro, Editora da Universidade do Estado do Rio de Janeiro, 1998, 22 pp.

; SIMÕES, Julio Assis. Sexualidade, cultura e política: a trajetória da identidade homossexual masculina na antropologia brasileira. cadernos pagu, n. 28, p. 65-99, 2007. 
$\mathrm{CHO}$, Grace M. Haunting the Korean diaspora: shame, secrecy, and the forgotten war. Minneapolis: University of Minnesota Press, 2008.

COELHO, Maria Claudia. Três mulheres no nazismo: Reflexões sobre as fontes do comportamento moral. Dilemas-Revista de Estudos de Conflito e Controle Social, v. 2, n. 5-6, p. 13-48, 2010.

DAS, Veena \& POOLE, Deborah. 2004. "State and its margins: comparative ethnographies". In: Veena Das \& Deborah Poole(orgs.), Anthropology in the margins of the State. Oxford: James Currency. pp. 3-33.

Life and words: violence and the descent into the ordinary. California: University of California Press, 2007.

DAVIS, Angela. Estarão as prisões obsoletas?. Editora Bertrand Brasil, 2018.

DELGADO, Pedro Gabriel Godinho. Saúde mental e direitos humanos: 10 anos da Lei 10.216/2001. Arquivos brasileiros de psicologia, v. 63, n. 2, p. 114-121, 2011.

DINIZ, Debora; BRITO, Luciana. "Eu não sou presa de juízo, não": Zefinha, a louca perigosa mais antiga do Brasil. História, Ciências, Saúde-Manguinhos, v. 23, n. 1, p. 113129, 2016.

DOCUMENTO, DE APARECIDA. texto conclusivo da V Conferência Geral do Episcopado Latino-Americano e do Caribe. São Paulo: Paulus, n. 243, 2007.

EFREM FILHO, Roberto. A reivindicação da violência: gênero, sexualidade e a constituição da vítima. cadernos pagu, n. 50, 2017.

FABIAN, Johannes. O tempo e o outro: como a antropologia estabelece seu objeto. Petrópolis: Editora Vozes, 2013.

FARIAS, Juliana. Fuzil, caneta e carimbo: notas sobre burocracia e tecnologias de governo. Confluências| Revista Interdisciplinar de Sociologia e Direito, v. 17, n. 3, p. 7591, 2015.

FASSIN, Didier. Compassion and Repression: The Moral Economy of Immigration Policies in France. Tradução de SILVA, Gleicy Mailly da; LOPES, Pedro. Cultural Anthropology, Vol. 20, No. 3, p. 362-387, agosto de 2005.

When bodies remember: Experiences and politics of AIDS in South Africa. University of California Press, 2007.

Humanitarian reason. A moral history of the present. Los Angeles: University of California Press, 2012, 352 pp.

FELTRAN, Gabriel de Santis. Irmãos: Uma história do PCC. São Paulo, Companhia das Letras, 2018. 
FERREIRA, Reuberson Rodrigues. Papa Francisco, e o método? Considerações sobre método ver-julgar-agir utilizado pelo Papa Francisco. Pensar-Revista Eletrônica da FAJE, v. 7, n. 2, p. 215-228, 2017.

FLEISCHER, Soraya. Descontrolada: Uma etnografia dos problemas de pressão. EdUFSCar, 2018.

FOUCAULT, M. Vigiar e punir: história da violência nas prisões. Petrópolis: Vozes, 1987.

Segurança, território, população: Curso dado no Collège de France (19771978). Tradução de Eduardo Brandão. São Paulo: Martins Fontes, 2008.

GAGNEBIN, Jeanne Marie. Lembrar escrever esquecer. São Paulo: Editora 34, 2006.

GOFFMAN, Erving. Manicômios, conventos e prisões. São Paulo: Perspectiva, 2005.

HARAWAY, Donna. Saberes localizados: a questão da ciência para o feminismo e o privilégio da perspectiva parcial. Cadernos pagu, n. 5, p. 7-41, 1995.

HARTMAN, Saidiya.Venus in two acts. Small Axe, 26, 12, (2), p. 1-14, 2008.

LAGO, Natália Bouças do. 2014. Mulheres na prisão: Entre famílias, batalhas e a vida normal. Dissertação de Mestrado. Faculdade de Filosofia Letras e Ciências Humanas, Universidade de São Paulo.

LHACER, Patrícia Maria Villa. Justiça, Cidadania e Saúde: Reflexões sobre Limites, Possibilidades e Desafios para a Implementação da Reforma Psiquiátrica nos Hospitais de Custódia e Tratamento Psiquiátrico em São Paulo. 2013. 295 f. Dissertação (Mestrado) - Curso de Saúde Pública, Universidade de São Paulo, São Paulo, 2013.

LOPES, Pedro. Negociando deficiências: identidades e subjetividades entre pessoas com "deficiência intelectual". 2014. Dissertação (Mestrado em Antropologia Social) Universidade de São Paulo, São Paulo, 2014.

MALLART, F. Findas linhas: circulações e confinamentos pelos subterrâneos de São Paulo. Tese apresentada ao Programa de Pós-Graduação em Sociologia do Departamento de Sociologia da Faculdade de Filosofia, Letras e Ciências Humanas da Universidade de São Paulo para obtenção do título de Doutor em Sociologia, 2019.

MARQUES, Adalton. Crime, proceder, convívio-seguro: um experimento antropológico a partir de relações entre ladrões. Dissertação de mestrado, FFLCH-USP, 2009.

.Humanizar e expandir: uma genealogia da segurança pública em São Paulo. São Paulo: IBCCRIM, 2018.256p.

MASSEY, Doreen B. Pelo espaço: uma nova política da espacialidade. Bertrand Brasil, 2008. 
MATSUDA, F. E. A medida da maldade: periculosidade e controle social no Brasil. Dissertação (Mestrado em Sociologia), Universidade de São Paulo, São Paulo, 2009.

MCCLINTOCK, Anne. Couro imperial: raça, gênero e sexualidade no embate colonial. Campinas, Editora da Unicamp, 2010.

MORAWSKA, Anna Catarina. Os enleios da tarrafa: etnografia de uma parceria transnacional entre ONGs através de emaranhados institucionais de combate à pobreza. 2010. Tese de Doutorado. Universidade de São Paulo.

A trilha de papéis da Usina Hidrelétrica de Belo Monte: tecnologias de cálculo e a liberação da perspectiva dos povos impactados. Revista Anthropológicas, Recife, 2014, v. 18, p. 22-40, 2014.

MOUTINHO, Laura. Razão, "Cor" e Desejo: Uma Análise Comparativa sobre Relacionamentos Afetivo-Sexuais "inter-raciais" no Brasil e na África do Sul. São Paulo: UNESP, 2004a, v. 1, 450p.

. Sexualidade, "raça" e direitos na África do Sul: primeiras reflexões. In: PISCITELLI, Adriana; GREGORI, Maria Filomena; CARRARA, Sergio. (Org.). Sexualidade e saberes: convenções e fronteiras. Rio de Janeiro: Garamond, 2004b, p. 345-363.

. Sobre danos, dores e reparações: The Moral Regeneration Movement controvérsias morais e tensões religiosas na ordem democrática sul-africana. In: TRAJANO FILHO, Wilson (org.). Travessias antropológicas: estudos em contextos africanos. Brasília: ABA, 2012, pp. 275-96.

MÜLLER, Herta. Sempre a mesma neve e sempre o mesmo tio. Globo Livros, 2013.

NADAI, Larissa. Entre estupros e convenções narrativas: os Cartórios Policiais e seus papéis numa Delegacia de Defesa da Mulher (DDM). Horizontes antropológicos, n. 46, p. 65-96, 2016.

of the State. Oxford: James Currency. pp. 3-33.

PADOVANI, Natália Corraza. "Perpétuas Espirais": Falas do poder e prazer sexual em trinta anos (1977-2009) na história da Penitenciária Feminina da Capital. 2010. Dissertação (Mestrado em Sociologia) - Departamento de Sociologia-IFCH. Unicamp, Campinas, 2010.

Pra (re) fazer Indiana Jones: crimes e caminhadas da antropólog (i) a nos processos de produção das "classes perigosas". Confluências $\mid$ Revista Interdisciplinar de Sociologia e Direito, v. 17, n. 3, p. 115-134, 2015.

. Sobre casos e casamentos: afetos e amores através de penitenciárias femininas em São Paulo e Barcelona. São Carlos: EDUFSCAR, 2018.

PASTORAL CARCERÁRIA NACIONAL. Formação para agentes da Pastoral Carcerária. São Paulo: Paulus, 2014, 86p. 
. Tortura em Tempos de Encarceramento em Massa. ASAAC, São Paulo, 2018.

Acesso em: https://carceraria.org.br/wpcontent/uploads/2016/10/Relat\%C3\%B3rio_Tortura_em_Tempos_de_Encarceramento em_Massa-1.pdf

PASTORAL CARCERÁRIA. Hospitais-prisão: notas sobre os manicômios judiciários em São Paulo. São Paulo, 2018. Acesso em: https://carceraria.org.br/wpcontent/uploads/2018/08/relatrio_hospitais-priso-gt-sade-mental-e-liberdadepastoral.pdf

RUFINO, Marcos Pereira. Águas da discórdia: a transposição das águas do Rio São Francisco e as mudanças de curso da missão indigenista católica. Revista de Antropologia, p. 15-44, 2013.

SCOTT, Joan W. A invisibilidade da experiência. Projeto História: Revista do Programa de Estudos Pós-Graduados de História, v. 16, 1998.

SOUZA LIMA, Antonio Carlos de. Apresentação. Dossiê Fazendo Estado. Revista de Antropologia vol.55, no 2, São Paulo, USP, 2012, pp.559- 564.

STOLER, Ann Laura. Along the archival grain: Epistemic anxieties and colonial common sense. Princeton University Press, 2010.

TSING, Anna Lowenhaupt. 2015. Margens indomaveis: cogumelos como espécies companheiras. Ilha. v.17, n.1, pp.177-201. Florianópolis.

. 2018. "Paisagens arruinadas (e a delicada arte de coletar cogumelos)". In:

Cadernos do Lepaarq, v. XV, n.30., p. 366-382.

VIANNA, Adriana; LOWENKRON, Laura. O duplo fazer do gênero e do Estado: interconexões, materialidades e linguagens. Cadernos Pagu, n. 51, 2017.

ZAMBONI, Marcio. O barraco das monas na cadeia dos coisas: notas etnográficas sobre a diversidade sexual e de gênero no sistema penitenciário. ARAC $\hat{E}$-Direitos Humanos em Revista, v. 4, n. 5, p. 93-115, 2017. 